NBER WORKING PAPER SERIES

\title{
CASHIER OR CONSULTANT? ENTRY LABOR MARKET CONDITIONS, FIELD OF STUDY, AND CAREER SUCCESS
}

\author{
Joseph G. Altonji \\ Lisa B. Kahn \\ Jamin D. Speer \\ Working Paper 20531 \\ http://www.nber.org/papers/w20531 \\ NATIONAL BUREAU OF ECONOMIC RESEARCH \\ 1050 Massachusetts Avenue \\ Cambridge, MA 02138 \\ September 2014
}

We thank Erica Blom and Sarah Amanda Levis for helping us with some early data issues, and David Card, Alex Mas, Paul Oyer, two anonymous referees, and seminar participants at CUNY, Columbia, Dartmouth, Duke, IZA, LSE, NBER, Queens University, University of Toulouse, and Yale University for helpful comments. The views expressed herein are those of the authors and do not necessarily reflect the views of the National Bureau of Economic Research.

NBER working papers are circulated for discussion and comment purposes. They have not been peerreviewed or been subject to the review by the NBER Board of Directors that accompanies official NBER publications.

(C) 2014 by Joseph G. Altonji, Lisa B. Kahn, and Jamin D. Speer. All rights reserved. Short sections of text, not to exceed two paragraphs, may be quoted without explicit permission provided that full credit, including $\odot$ notice, is given to the source. 
Cashier or Consultant? Entry Labor Market Conditions, Field of Study, and Career Success Joseph G. Altonji, Lisa B. Kahn, and Jamin D. Speer

NBER Working Paper No. 20531

September 2014

JEL No. J24,J31

\begin{abstract}
$\underline{\text { ABSTRACT }}$
We analyze the early labor market outcomes of U.S. college graduates from the classes of 1974 to 2011, as a function of the economic conditions into which they graduated. We have three main findings. First, poor labor market conditions substantially disrupt early careers. A large recession at time of graduation reduces earnings by roughly $10 \%$ in the first year, for the average graduate. The losses are driven partially by a reduced ability to find employment and full-time work and partially by a roughly $4 \%$ reduction in hourly wage rates. Second, these effects differ by field of study. Those in majors with typically higher earnings experience significantly smaller declines in most labor market outcomes measured. As a result, the initial earnings and wage gaps across college majors widen by almost a third and a sixth, respectively, for those graduating into a large recession. Most of these effects fade out over the first 7 years. Those in higher paying majors are also slightly less likely to obtain an advanced degree when graduating into a recession, consistent with their relative increase in opportunity cost. Our third set of results focuses on a recent period that includes the Great Recession. Early impacts on earnings are much larger than what we would have expected given past patterns and the size of the recession, in part because of a large increase in the cyclical sensitivity of demand for college graduates. The effects also differ much less by field of study than those of prior recessions.
\end{abstract}

Joseph G. Altonji

Department of Economics

Yale University

Box 208264

New Haven, CT 06520-8264

and NBER

joseph.altonji@yale.edu

Lisa B. Kahn

Yale University

School of Management

P. O. Box 208200

New Haven, CT 06520

and NBER

lisa.kahn@yale.edu
Jamin D. Speer

University of Memphis

jspeer@memphis.edu 


\section{Introduction}

The impact of the Great Recession was widespread, with unemployment rates doubling for nearly all subgroups of the population. Recent college graduates, whose unemployment rate increased from $9 \%$ in 2007 to a peak of $17.6 \%$ in 2009 , were no exception. ${ }^{1}$ Research on previous recessions suggests this group will experience significant earnings losses over their careers, relative to their luckier counterparts who graduated just before or just after the recession. ${ }^{2}$ Research also suggests that college graduates face sizeable earnings differences depending on their field of study. ${ }^{3}$ It is natural to then ask whether, and how, earnings differences across field of study interact with the business cycle. What kinds of students are most prone to the impacts of entry conditions? Does an engineering student, who typically earns $75 \%$ more than an education major, retain or even expand that advantage when graduating into a recession? Or, does the general lack of opportunity compress these earnings differences?

Why might recent graduates be particularly sensitive to economic conditions? Workers graduating into a recession will likely match to lower level starting jobs than their luckier counterparts (Devereux 2002). Highly mobile young workers (Topel and Ward 1992) may recover from early set-backs through job movement, though perhaps more gradually in the face of fewer vacancies per worker. However, a poor early start, possibly including time spent in unemployment, could put college graduates in jobs with fewer training and promotion opportunities, resulting in a lasting disadvantage. ${ }^{4}$

Why might the effects of economic conditions at graduation depend on field of study? College majors differ widely in the skill requirements of their degrees and subsequent jobs,

\footnotetext{
${ }^{1}$ These numbers are from the School Enrollment Supplement to the Current Population Survey and are based on graduates aged 20 to 29 who completed a bachelor's degree in the calendar year of the survey.

${ }^{2}$ Kahn (2010) estimates that white men graduating in the worst part of the 1981-82 recession earned over $20 \%$ less, relative to those graduating in nearby peaks, and these effects partially persisted for 15-20 years. Oreopoulos, von Wachter, and Heisz (2012) find somewhat similar effects on men in Canada over a twenty-year period, though magnitudes and persistence are weaker. They also find impacts are worse for lower-skilled college graduates.

${ }^{3}$ For example, Altonji, Blom, and Meghir (2012) show that earnings differences across college majors can be as large as the overall college-high school premium. They provide a survey of the literature on the returns to college major.

${ }^{4}$ Though the literature on the career effects of entry conditions is sparse on underlying mechanisms, Kahn (2010) suggests that human capital disparities are a likely driver. Consistent with this notion, effects are typically worse for higher human capital individuals for whom post-schooling skill accumulation is likely more important. For example, college graduates face larger, more persistent impacts than do high school graduates; white men experience worse wage outcomes than women and minorities (see Kondo (2008) and Hershbein (2012)). Human capital disparities across cohorts arise in Gibbons and Waldman's (2006) task-specific human capital model where workers entering firms in worse economies start out in lower level jobs and therefore lag behind on task-specific human capital in more important jobs years later. The Gibbons-Waldman model was designed to explain (among other things) persistent earnings differences across firm-entry cohorts found in Baker, Gibbs, and Holmstrom (1994). In contrast Beaudry and DiNardo (1991) show that while labor market conditions at point of entry into a firm matter, the best labor market over a worker's tenure matters most for earnings. They posit this is driven by bargaining and imperfect mobility.
} 
as well as their labor market opportunities in good times. ${ }^{5}$ These differences could result in a differential ability to find good initial placements, which could lead to better career trajectories or help avoid path dependence and earnings losses that come from time spent outside of full-time work (Kroft, Lange, and Notowidigdo (2013), Bertrand, Goldin, and Katz (2010)). Ability differences might also translate into a differential ability to upgrade from poor initial placements. ${ }^{6}$ It is also likely that training opportunities and skill appreciation will be more important for career paths in some majors than in others. For high-return majors, post-schooling human capital accumulation might be more important (though this is actually an open question), yielding more scope for negative impacts of entry conditions. Will a general higher ability of high-return majors help them weather an early downturn, or will a potential for greater mismatch between the degree and opportunities for skill accumulation and advancement in initial job placements cause relatively worse outcomes?

In this paper, we analyze the short- and medium-term career outcomes of college graduates as a function of economic conditions at graduation and college major. The data requirements are formidable. We combine seven data sets with information on earnings and field of study for U.S. college graduates graduating between 1974 and 2011. The "combined" data set yields coverage of multiple business cycles and features larger sample sizes than the typical cohort-based analyses in this literature. We characterize 51 college majors by the average earnings premium in the major. We then estimate impacts of graduating in times of higher unemployment across these skill groups for a range of labor market outcomes over the first 13 years of a career.

We address three main questions. First, what is the effect of graduating into a recession for the average college major? We improve on previous research by examining this question over a long time period in the U.S. with multiple expansions and recessions. Second, how does the effect of a recession vary by college major? Third, have the answers to these questions changed in the Great Recession?

Consistent with the previous literature, we find that graduating from college in times of higher unemployment is associated with significant earnings losses for the average major. ${ }^{7}$ Earnings decline by roughly $10 \%$ in the first year after graduation for a worker who graduated with a four percentage point higher unemployment rate (the increase seen in a

\footnotetext{
${ }^{5}$ For example, Turner and Bowen (1999) show substantial variation in average SAT scores across college major, and Arcidiacono (2004) and Altonji et al. (2012) show that the ordering of majors by average earnings is very similar to the ordering by average SAT math score.

${ }^{6}$ Shimer (2004) points out that the expected return to job search will positively impact search intensity, and Oreopoulos et al. (2012) view their finding that in Canada, more-skilled graduates catch up more quickly from poor initial conditions as supporting a model of differential search intensity. Furthermore, Wozniak (2010) finds that geographic location choices of college graduates are more sensitive to local labor market conditions than are those of high school graduates, supporting the idea that higher-skilled workers search more intensively.

${ }^{7}$ This summary of the evidence for the average major is based on estimates from our combined data set as well as those from the March CPS, where we do not know college major, but can estimate the effect of entry conditions for the average graduate.
} 
large recession). This effect partially persists for the first several years of a career, averaging to a roughly $1.8 \%$ earnings loss per year over the first 10 years. This result is similar to Oreopoulos et al.'s (2012) estimate but smaller and less persistent than Kahn's (2010).

We then examine the channels through which recessions affect labor market outcomes, focusing on employment, full-time status, wage rates, and occupational attainment. We find that the earnings losses are accounted for by a combination of hours reductions and wage rate reductions. We find only modest impacts on the probability of being employed but larger impacts on the probability of working full-time. Workers are about 5 percentage points less likely to be working full time in their first year out of college, though this effect does not persist past the first three years after graduation. Wages are $4 \%$ lower in the first year after graduating into a large recession, and average about $1.5 \%$ per year over the first 10 years. We also find small negative impacts on occupation quality, as measured by the earnings return to the occupation, but no effect on occupation match quality, as measured by whether the occupation is typical for one's major.

Regarding the second question, we find that those in high-paying majors are somewhat sheltered from the negative effects of graduating into a recession. A major that typically earns one standard deviation above the mean (such as civil engineering or accounting) experiences only about half the earnings losses of a major that typically earns at the mean (journalism or engineering technology). This means that high-return majors increase their earnings advantage by almost a third when graduating into a large recession, and this effect persists for 7 years into a career. By the same token, those in fields that typically earn one standard deviation below the mean (fitness and nutrition, commercial art and design) experience earnings losses that are about 50 percent larger than those of the average major.

The differential earnings effect across college majors is due to a combination of differential effects on wages, employment, occupational attainment, and hours. For example, highearning majors increase their wage advantage by $15 \%$ when graduating into a large recession, and this effect persists for several years. Occupations also seem to be an important margin for the differential effects. Higher earning majors are differentially more likely to be in higher paying occupations and in occupations that are typical for their major. ${ }^{8}$

Educational attainment might also be impacted by labor market entry conditions because they change the opportunity cost of remaining in school. Most research has focused on the impact of local labor market conditions on high school completion and college enrollment, and surprisingly little attention has been paid to the graduate school decision. ${ }^{9}$ We examine

\footnotetext{
${ }^{8}$ Liu, Salvanes, and Sorensen (2012) analyze the effects of graduating from college into a recession in Norway and find initial impacts on wage rates as well as persistent impacts on unemployment. They show that an important channel through which these effects operate is the ability to find work in a high-paying industry. Similarly, Oyer (2008) finds persistent earnings losses for MBAs graduating into recessions, attributing much of this effect to initial industry placement. Oyer (2006) also finds persistent effects of entry conditions on prestige of institution for economics PhDs.

${ }^{9}$ Exceptions include Kahn (2010) on educational attainment, and Bedard and Herman (2008) and Johnson (2013) on enrollment. See, for example, Card and Lemieux (2001) for more on high school graduation and
} 
the probability of attaining an advanced degree and find small positive effects for those graduating into a recession. These effects are muted for higher-skilled majors, consistent with the relative changes in opportunity costs. This represents the broadest evidence to date on the subject of graduate educational attainment.

It is possible that the relative advantage of higher-skilled majors graduating into a recession is driven by a differential cyclicality in their labor demand. ${ }^{10}$ To examine this mechanism, we construct and analyze the cyclicality of a major-specific unemployment rate; this is the first such analysis to our knowledge. We use annual Current Population Survey data and the industry-occupation distribution for each major from a subset of our data to construct the unemployment rate in the industry-occupation cells that a given major tends to enter into. We indeed find a negative correlation between skill level and cyclicality of the major-specific unemployment rate, but it is small. A one standard deviation increase in skill level of the major reduces its cyclicality by only $10 \%$, relative to the average major.

The final set of results concerns those who graduated into the Great Recession of 2007-09. First, we present evidence that 2004-2011 graduates saw much larger per-unit impacts of the aggregate unemployment rate on earnings - between two and three times the size of the earlier period. We document that these changes are associated with a large increase in the cyclicality of demand for college graduates. Second, the relative advantage of high-skilled majors graduating into a recession has been cut in half. This may be due in part to an increase in cyclicality of demand for high-skilled majors relative to the average major, although this is probably only part of the story. Therefore, it appears that the Great Recession was much harsher overall for recent graduates than we would have expected given the size of the aggregate unemployment rate increase, and these effects were more evenly distributed across majors.

Our work is most closely related to Oreopoulos et al. (2012), who use Canadian universityemployer-employee matched data to study the earnings effects of graduating in times of higher unemployment, and how these effects vary with the skill level of the graduate. They find smaller and less persistent effects for workers who went to better schools, majored in more difficult subjects, and received better grades. They find that these groups are able to catch up more quickly through upgrading on firm quality. Our result that higher-skilled majors fare relatively better when graduating into a worse economy is entirely consistent with their work. We offer the first results on this question for the United States, and provide an analysis over a long time horizon with large sample sizes. We also measure a number of other outcomes, such as employment, wage rates and occupational and educational attainment, that were unavailable in the administrative data set used by Oreopoulos et al. (2012). Though we cannot measure firm quality in our data, we use occupation earnings differentials

college attendance as a function of local labor market conditions.

${ }^{10}$ Since those with high-return majors tend to work in high-paying industries, such a mechanism would be inconsistent with the literature on cyclical upgrading. That literature finds that employment in higher paying industries is more cyclical than in lower paying industries (Bils and McLaughlin 2001). 
and the propensity to be in a popular occupation given one's major to assess the quality of jobs workers enter into over the business cycle and across college major.

This paper proceeds as follows. We discuss our data sources and some measurement issues in section 2 before describing methodology in section 3. Section 4 presents our core results on earnings, wages, employment, and occupational and educational attainment for the average graduate and discusses how these results have changed for graduates in recent years, including the Great Recession. Section 5 examines differential effects across major, including an examination of the effects of recessions and college major on graduate education. Section 6 examines demand cyclicality across college majors as a potential explanation for our results. Section 7 concludes.

\section{Data}

\subsection{Data Sources}

In order to estimate the short- and medium-term effects of initial economic conditions on labor market outcomes across college major, with coverage over several national expansions and contractions, we pool multiple data sources: two National Longitudinal Surveys of Youth (the NLSY79 and NLSY97), the National Survey of College Graduates for 1993 (NSCG93) and 2003 (NSCG03), the Baccalaureate and Beyond 1993 (BB93) and 2008 (BB08), the National Longitudinal Study 1972 (NLS72), the Survey of Income and Program Participation (SIPP) 1984 through 2008 panels, and the American Community Survey (ACS) from 2009$2012 .^{11}$

These surveys are chosen because they contain information on both college major and labor market outcomes. To better align the length of time individuals can be observed postcollege graduation across data sets, we restrict attention to workers between ages 22 and 35 and those who are between 0 and 13 years out of college. ${ }^{12}$ The pooled data contain college graduates who graduated between 1974 and 2011, with an unbalanced panel of labor market outcomes measured from 1977 to 2012. ${ }^{13}$ Appendix table 1 reports this coverage by survey. We provide a description of each survey and details of specific variable creation in the online data appendix.

\footnotetext{
${ }^{11}$ We do not use the 1985 SIPP panel, which does not have college major information, or the 1989 SIPP panel, which was abandoned and did not produce enough follow-up waves to be useable.

${ }^{12}$ We also exclude workers who graduated before age 20 or after age 24 (roughly a quarter of graduates in surveys where we can determine timing of college graduation). We feel it is appropriate to restrict attention to a sample that more closely represents the typical student. In all surveys but the ACS, we know or can infer year of college graduation. For the ACS, we take advantage of quarter of birth information to impute graduation year as the year an individual was likely age 22 in May of that year, the most common graduation age in the other data sets.

${ }^{13}$ Though we also have data on college graduates from 1971-73, the samples are small in those years, and are therefore lost when we apply cell-size restrictions, described below.
} 
The goal in this paper is to estimate the impacts of entry conditions on subsequent labor market outcomes. We use the census division unemployment rate in the year of college graduation as an indicator of entry conditions, hereafter $U_{c}$. The subscript $c$ stands for the college graduation cohort, which we define as a division-graduation year. ${ }^{14}$ The unemployment rate is highly visible and is the most commonly used measure of economic conditions in prior work (see, for example, Kahn (2010) and Oreopoulos et al. (2012)). ${ }^{15}$

To provide a sense of sample coverage, appendix table 2 presents the number of observations in the pooled sample by $U_{c}$ and years since graduation (hereafter potential experience). We have substantial sample sizes at both low and high levels of unemployment. However, the pooled data are heavily skewed towards low graduation-year unemployment rates. This is because the ACS is much larger than the other data sets and its graduates tend to be from low unemployment years (with the exception of the most recent graduates from these surveys, who graduated into the Great Recession). This feature of our data leads us to employ a two-step estimation procedure, described in more detail below, that allows us to put equal weight on each cohort-potential experience cell. With this approach we can characterize the overall impact of graduating into a period of high unemployment across the long time period spanned by our data sets. Estimates from an unweighted sample would instead primarily reflect the recent period. Since the nature of labor market shocks surely varies over time, we also report how the effects of entry conditions differed in the years surrounding the Great Recession.

This collage of data (hereafter, the combined sample) affords a number of advantages over the previous literature - for example, the excellent coverage displayed in appendix table 2 , as well as the ability to analyze the differential effects of entry conditions across college major. However, surveys will naturally differ to some extent in terms of variable definitions, sample sizes, and coverage. Below, and in the data appendix, we describe our efforts to create a uniform data set, despite these differences. We also provide a companion analysis using the Current Population Survey March Supplement (CPS). The main advantage of the CPS is that it provides fairly uniform coverage of labor market outcomes for all potential experience levels over a long time period. Its main disadvantages for our purposes are that it does not identify year of graduation or census division of graduation, and it does not contain information on college major. However, we can analyze the impact of entry conditions for the

\footnotetext{
${ }^{14}$ We use annual measures from the Bureau of Labor Statistics to reduce noise in the measure itself and because we cannot determine month of graduation in most data sets.

${ }^{15}$ Our results are robust to using national unemployment rates, as well as state-level rates. While the national economy is likely the most relevant for college graduates, a more disaggregated measure provides useful variation to supplement the time series. However, local unemployment rates introduce noise generated by our inability to pinpoint the location of college graduation in some surveys. We instead must sometimes impute state of college graduation with current location of residence (see the online data appendix for details). Balancing these tensions, we compromise with the 9 census divisions as the geographic level of analysis. This takes advantage of spatial variation in entry conditions but does not generate as much additional noise as imputing state of college graduation - even if workers move across state lines after college, they are less likely to move across divisions.
} 
average major, imputing timing of graduation by using the year of birth and assuming census division at graduation is the same as current census division. We present these alongside results from our main data set in section 4 .

\subsection{Labor Market Outcome Measures}

In the subsequent sections, we measure the impacts of $U_{c}$ on annual earnings, wage rates, employment, full-time employment (working at least 35 hours per week), and occupational attainment. We pay particular attention to defining these variables as consistently as possible across surveys. (See online appendix table 1 for a detailed description of variable creation across surveys).

In all analyses we exclude enrolled workers to better isolate prime work experience. ${ }^{16}$ Our primary outcome of interest is annual earnings over the previous calendar year or 12month period, since this measure reflects earning power as well as the ability to obtain work hours. ${ }^{17}$ For wages and occupation outcomes (described in more detail in section 4) we restrict attention to those with a valid earnings measure so we can use these variables to diagnose the earnings effect. ${ }^{18}$ We also analyze employment and full-time employment (working at least 35 hours per week) on the full sample (with no earnings restrictions).

In table 1, we report weighted summary statistics, calculated by assigning equal weight to each cohort-potential experience cell. This most closely represents the weighting for the twostep estimation procedure described below. Panel A summarizes variables for the earnings sample. Average annual earnings in our data is about $\$ 47,000$ in 2006 dollars. The average graduation year is 1990 and the average year of an earnings observation is 1997. As noted above, the pooled sample yields substantial variation in the unemployment rate at time of graduation, ranging from $2.8 \%$ to $12.5 \%$. In the earnings sample, $96 \%$ were employed and $87 \%$ were employed full time. Without earnings restrictions (the sample used to study these outcomes), the employment rate and the full-time employment rates are $89 \%$ and $77 \%$, respectively.

\subsection{Characteristics of College Majors}

A primary goal of this paper is to estimate the differential effects of labor market conditions across college majors. In most data sets, we can easily classify college major into a set of

\footnotetext{
${ }^{16}$ In the NSCG93, we cannot infer enrollment status. In the NLS72, we do not have enrollment status after 1976.

${ }^{17}$ We restrict the sample to those earning at least $\$ 500$ (in 2006 dollars) and top code at $\$ 400,000$. We exclude earnings in the year of college graduation since this could partially reflect income while in school. Earnings in the NSCG93 (non-census measure), NSCG03, and BB93 reflect annual salary in the current job, since realized annual earnings is not available.

${ }^{18}$ Wages are further restricted to be greater than $\$ 0$ and are bottom- and top-coded to be between $\$ 5$ and $\$ 250$ per hour.
} 
51 categories commonly used by the Department of Education. ${ }^{19}$ In principle, we could estimate a separate $U_{c}$ effect for each of the 51 major categories, but that quickly becomes intractable. Instead we categorize majors by the typical earnings return to the major and ask whether high- and low-return majors are differentially impacted by entry conditions.

We regress log earnings on major fixed effects and controls in the pooled data (excluding the SIPP) on a sample of older workers (age 36 to 59) with at least a college degree who report being employed full time. ${ }^{20}$ The age restriction excludes the regression sample used to estimate the effect of entry conditions on labor market outcomes, reducing any simultaneity concerns. $^{21}$ We then standardize the major fixed effects to be mean zero and standard deviation one. ${ }^{22}$ We denote these standardized fixed effects as $\beta^{\text {major }}$.

Table 2 reports the values of $\beta^{\text {major }}$ for each of the 51 Department of Education major categories, from highest to lowest. ${ }^{23}$ Chemical and electrical engineering, finance, and economics have the highest earnings returns, while philosophy and religion, several arts fields, and library science and non-secondary education have the lowest. ${ }^{24}$

\section{$3 \quad$ Econometric Model and Methods}

\subsection{Regression Specification}

To estimate the effect of the unemployment rate at graduation on labor market outcomes, and how this varies across college majors, we use the following specification.

$$
\begin{aligned}
Y_{i c t}=\beta_{1} X_{i t} & +\beta_{2} U_{c}+\beta_{3} U_{c} P E_{i t}+\beta_{4} U_{c} P E_{i t}^{2}+\beta_{6} \beta_{i}^{\text {major }} P E_{i t} \\
& +\beta_{7} \beta_{i}^{\text {major }} U_{c}+\beta_{8} \beta_{i}^{\text {major }} U_{c} P E_{i t}+\gamma_{\text {major }}+\epsilon_{i c t}
\end{aligned}
$$

\footnotetext{
${ }^{19}$ The exception is the SIPP, which has one classification of 20 categories in panels 1984-1993 and another with 18 categories from 1994-2008. We explain how we use and combine these categories below.

${ }^{20}$ The controls in this regression are identical to those used in our main specification, described below, (excluding $U_{c}, \beta^{\text {major }}$ and their various interactions) except here we include a third order term in potential experience since this sample is much older. We also control for whether the worker has obtained an advanced degree to help distinguish the return to the major from returns to postgraduate education. We weight this regression with survey weights that are normed so that the weight of each survey is proportional to its size.

${ }^{21}$ This age restriction necessarily excludes the NLS72, the NLSY97, and both BB panels.

${ }^{22}$ For the SIPP, which contains two separate major classifications, we estimate a similar log earnings regression, treating the sets of 20 and 18 major classifications as roughly 38 separate majors, and obtain major fixed effects. We standardize these by subtracting the mean for the SIPP majors and dividing by the standard deviation of the non-SIPP majors, so that the units are comparable. Note that the age and education sample restrictions are identical to those for the pooled sample, but in SIPP the full-time restriction is imposed by retaining only those who were employed full-time in at least three-quarters of the survey months that year.

${ }^{23}$ Values for the two SIPP classifications can be found in online appendix tables $2 \mathrm{a}$ and $2 \mathrm{~b}$.

${ }^{24}$ It is important to note that a few of the categories combine majors that pay quite differently. An extreme case is "philosophy and religion", which combines philosophy, a relatively high paying humanities major, with religious studies, which pays less, and theology and religious vocations, which pays substantially less. Altonji et al. (2012, supplemental table 3) report that "philosophy and religious studies" majors earn about $30 \%$ more than "theology and religious vocations" majors.
} 
In equation (1), $Y_{i c t}$ is a labor market outcome measured in year $t$, for an individual $i$, in college graduation cohort $c$ (division-graduation year), and $X_{i t}$ is a set of control variables. ${ }^{25}$ We also control for major fixed effects $\left(\gamma_{\text {major }}\right)$, and allow the earnings return to the major, $\beta^{\text {major }}$, to vary with $P E_{i t}$ (potential experience). ${ }^{26}$ We define $P E_{i t}$ as the number of years since college graduation rather than actual labor market experience, which could be endogenously related to $U_{c}$ and is not observed in most of our data sets. ${ }^{27}$

$U_{c}$ measures labor market entry conditions, defined as the deviation of the division unemployment rate from the sample mean of $6.3 \%$ in the year of college graduation. The coefficient $\beta_{2}$ on $U_{c}$ measures the impact of entry conditions on initial labor market outcomes (the year following graduation). ${ }^{28}$ Since $\beta^{\text {major }}$, the earnings return to the major, is standardized to be mean 0 , the main effect of $U_{c}$ is the impact for the average major. ${ }^{29}$ To measure the persistence of this impact, we interact $U_{c}$ with a quadratic in $P E_{i t}$. Results are robust to only including a linear interaction, and to controlling for potential experience with 3-year buckets and allowing these to interact with $U_{c}$.

The coefficient $\beta_{7}$ measures the differential impact of entry conditions across college major on initial labor market outcomes. We include the three way interaction $\beta_{i}^{\text {major }} U_{c} P E_{i t}$ to allow the differential effect to vary with experience. Again, results are not sensitive to the functional form of the persistence term. ${ }^{30}$

\footnotetext{
${ }^{25}$ The controls included in $X_{i t}$ are survey fixed effects, a quadratic in potential experience, gender, race/ethnicity, gender interacted with race/ethnicity and potential experience, division of graduation fixed effects, and a cubic time trend in $t$. Survey fixed effects are: NLSY79, NLSY97, NSCG93, NSCG93 data from the 1990 decennial census, NSCG03, BB93, BB08, NLS72, early SIPP (panels 1984-1993), later SIPP (panels 1996-2008), and the ACS (waves 2009-2012). As we describe below, some of these will enter into the first step regression while others enter into the second step.

${ }^{26}$ We treat the early and late SIPP major categories as separate majors from the 51 Department of Education categories. This gives us a total of 89 majors.

${ }^{27}$ In practice, we subtract 1 from $P E_{i t}$ so that the interaction terms are 0 in the year after graduation, yielding a more natural interpretation for the main effects (the first year after graduation).

${ }^{28}$ One might worry that students endogenously respond to labor market conditions when choosing when to graduate from college. Kahn (2010) addressed this issue by instrumenting for graduating conditions with the unemployment rate at age 22 . As a robustness check, we estimate the reduced form based on this instrument (since our two-step estimation procedure makes instrumenting difficult). Specifically, we replace $U_{c}$ with a weighted average of unemployment rates experienced at age 22 and 23 , with two-thirds weight on the former and one-third on the latter. We use the weighted average because graduation ages have increased compared to Kahn's sample period. We obtain very similar results, suggesting endogenous timing of college graduation is not a concern. One might also be concerned that students choose their college major in response to the business cycle. Blom (2012) does find that students shift to higher-return majors when economic conditions are worse at age 20, resulting in an increased supply and possible negative selection of high-return majors graduating into a recession, relative to a boom. This selection would work against our findings below that high-return majors fare relatively better than low-return majors when graduating into a recession.

${ }^{29}$ We standardized based on the regression sample used to estimate $\beta^{\text {major }}$. Thus the "average major" is defined on the sample of workers age 36-59, employed full-time, with more weight placed on the larger data sets.

${ }^{30}$ Results are robust to a number of additional control variables. Specifically, the inclusion of surveygraduation year fixed effects and survey-potential experience interactions, and $\beta^{\text {major }}$ interacted with a cubic time trend do not change the point estimates and actually improve precision. The survey interactions are useful since outcome measures vary slightly across surveys (see online appendix table 1). The time trend in $\beta^{\text {major }}$ controls for differences in the return to skills over time. Results are also robust to educational attainment controls, though we prefer to omit these since they could be endogenously related to labor market
} 
Note that the interpretation of the parameters is affected by the fact that entry division unemployment rates are positively correlated with the unemployment rates at 1 and 2 years experience, so a worker leaving school in a recession is likely to experience more than just one bad year of labor market conditions. ${ }^{31}$ Since we do not control for unemployment rates between the time of graduation and $t$, the terms involving $U_{c}$ absorb the effects of variation in labor market conditions between $c$ and $t$. Our results can then be interpreted as the overall effect of graduating into a time of high unemployment, say, including a part that arises because the worker is likely to experience a couple of years of bad conditions. We could instead isolate the partial effect of $U_{c}$ by controlling for the values of unemployment during the years between $c$ and $t$. Results are qualitatively robust to this specification, which we discuss in more detail below. ${ }^{32}$

\subsection{Two-Step Estimation Procedure}

In practice, we cannot obtain the average effect of $U_{c}$ over the entire sample period by estimating the regression model in equation (1) on the pooled data. These data are not balanced across time or across experience levels and are instead heavily skewed towards recent cohorts because of the ACS. We would prefer to weight the data more equally across years; this is especially important if the effect of $U_{c}$ varies over time.

One way to estimate average effects over the time period we study is to weight each cohort-potential experience cell equally. However, this method is accompanied by a large loss in efficiency, since it upweights noisy small cells and downweights precisely estimated large cells. There is no way around some degree of inefficiency if we want equal weighting. However, we attempt to retain some of the precision given in the larger cells through a two-step estimation procedure.

We first estimate a regression of a labor market outcome on the control variables, weighting observations with survey weights (to take full advantage of the extra precision from larger data sets). We then collapse residuals to the major-cohort-potential experience cell (we denote this $m c p$-level, where $m$ is major, $c$ is division-graduation year, and $p$ is potential experience) and use these in a second step regression to estimate the coefficients of interest. ${ }^{33}$ In this second step regression, we weight the data so that the distribution of observations

entry conditions. Instead we examine educational attainment as an outcome in table 6 below.

${ }^{31}$ The partial correlations of division unemployment rates between $t$ and $t+1$, and between $t$ and $t+2$ are 0.78 and 0.40 , respectively, controlling for division fixed effects and a cubic time trend. They are small and insignificant for the next several years thereafter.

${ }^{32}$ This robustness analysis closely follows that of Oreopoulos et al. (2012).

${ }^{33}$ In the first step regression, we include survey fixed effects, gender, race/ethnicity, the interaction between gender and race/ethnicity, and interactions of potential experience with gender and with race/ethnicity. Thus, our estimates of the mcp fixed effects control for differential sorting across majors by gender and race/ethnicity. The remaining controls are included in the second step along with the key explanatory variables. We also include survey dummies in the second step because some of them are dropped in the first stage due to collinearity within $m c p$-cell. Because values in the second step are collapsed to the $m c p$-level, the survey controls are the shares of each data set within each cell. 
across college majors, $m$, in a given $c p$-cell, matches the empirical distribution, but each $c p$-cell gets the same weight. ${ }^{34}$

Since the unit of observation in the second step is at the mcp-level, we are naturally worried that some cells made up of very few observations will have too large an influence. We address this concern in two ways. First, we drop all observations from graduation yearpotential experience cells with fewer than 100 observations to eliminate the influence of the smallest cells. ${ }^{35}$ Second, we trim the $m c p$-cell fixed effects from the first stage regression to eliminate extreme outliers. ${ }^{36}$ We then estimate the second-step regression described above.

In practice, we vary the control variables in the second-step regression depending on the parameters of interest, balancing concern for bias against concern for sampling error. The choice of controls drives the choice of how to cluster when estimating standard errors. When estimating the coefficients $\beta_{2}, \beta_{3}$, and $\beta_{4}$ on $U_{c}, U_{c} P E$ and $U_{c} P E^{2}$, we exclude graduation year fixed effects. This exclusion allows both national and division-specific time series variation to contribute to identification of these parameters. Using the national variation reduces sampling error and reduces possible downward bias if division-specific variation in labor market conditions matters less for college graduates than national variation. On the other hand, unobserved trends in graduation year cohort characteristics could potentially affect the estimates. ${ }^{37}$ The standard errors for $\beta_{2}, \beta_{3}$, and $\beta_{4}$ are clustered by cohort (division-graduation year), the level of variation underlying $U_{c}$.

For the parameters $\beta_{7}$ and $\beta_{8}$ governing the differential effects of $U_{c}$ across $\beta^{\text {major }}$, time series variation is less important because of the variation in $\beta^{\text {major }}$, so we include graduation year fixed effects. Given these and the major fixed effects, we prefer to use robust standard errors that simply account for heteroskedasticity. Standard error estimates are typically larger when we instead cluster at the major-cohort level, but conclusions about statistical significance remain the same in most cases. For example, in the earnings regression, the standard error for the coefficient on $U_{c} \beta^{\text {major }}$ is about $25 \%$ larger when clustering at the major-cohort level. ${ }^{38}$

\footnotetext{
${ }^{34}$ Specifically, we weight the second-step regression by the number of observations for a given dependent variable in the $m c p$-cell divided by the number of observations in the $c p$-cell.

${ }^{35}$ For earnings, wages, and occupational attainment, we restrict the analysis to cells with at least 100 earnings observations, to keep these samples as similar as possible. This removes about 19,000 person-year observations, or $2.7 \%$ of our pooled, unweighted data. For employed and full-time status we drop cells with less than 100 observations for employed, removing about 4,000 observations, or $0.5 \%$ of our data.

${ }^{36}$ We compute the residuals from a median regression of the mcp-cell fixed effects on survey controls, a cubic time trend, a quadratic in $P E, \beta^{\text {major }}$, and $\beta^{\text {major }} * P E$, using second-stage regression weights. We drop cells whose median regression residuals are in the top and bottom $2 \%$. Trimming eliminates roughly $0.6 \%$ of the unweighted pooled sample. It does not change the point estimates, but improves precision considerably.

${ }^{37}$ In practice, we obtain similar results when we use only the divisional variation by including graduation year fixed effects.

${ }^{38}$ We ignore serial correlation across clusters that might arise from sampling error in the estimated regressors that we use, including $\beta^{\text {major }}$, because we think it is a second order issue in our case. See Murphy and Topel (1985).
} 


\section{The Effects of Entry Conditions on the Average Grad- uate}

In this section, we discuss the impact of entry conditions on labor market outcomes for the average major. The large sample sizes and the long time period covered by the main sample and by the CPS represent a considerable improvement over the previous evidence on this question for the U.S. We point out differences between the combined sample results and the CPS results as we go along, and provide a summary assessment at the end of section 4.1. We begin with the evidence for the full sample period and then show that effects have become larger in recent years.

\subsection{Estimates for the Full Sample Period}

Table 3 reports the impact of graduating into a large recession on a number of labor market outcomes for workers at various experience levels, from the combined sample. We define "large" as a 4 ppt increase in $U_{c}$, the approximate shift of the national unemployment rate in the large 1981-82 and 2007-09 recessions. ${ }^{39}$ The regression coefficients underlying the results in table 3 can be found in appendix table 3 and online appendix tables $3-7 .{ }^{40}$

We begin with annual earnings in panel A, column 1. Row 1 displays the average impact of graduating into a large recession on log annual earnings across the first 10 years of experience, -0.0135 (with a standard error of 0.011 ) $\log$ points per year. ${ }^{41}$ The subsequent rows report the experience profile starting with a large 0.118 (0.024) log point earnings loss in the first year out of school. This effect falls to $0.04 \log$ points after 3 years of experience, but remains significant at the $1 \%$ level. The effect is entirely gone by year $7 .{ }^{42}$

In table 4 , we report estimates based on the CPS. ${ }^{43}$ The effect of $U_{c}$ is smaller initially - a

\footnotetext{
${ }^{39}$ Since the model is linear in $U_{c}$ and the parameters are identified by variation associated with booms as well as recessions, our estimates equally apply to a 4 ppt shift from a large boom to an average economy and can be used to characterize the advantage of graduating in a boom. We do not find evidence that the effect of $U_{c}$ is nonlinear. See section 4.2 .

${ }^{40}$ Estimates in table 3, column 1 can be calculated from the column labeled (1) in appendix table 3 , by computing $\hat{\beta}_{2} \cdot 4+\hat{\beta_{3}} P E \cdot 4+\hat{\beta}_{4} P E^{2} \cdot 4$ for the specified value of $P E_{i t}$. Other columns of table 3 can be computed similarly using online appendix tables $3-7$.

${ }^{41}$ We fit an unweighted average across the first 10 years to avoid impacts of sample composition.

${ }^{42}$ As mentioned above, the estimated effect of $U_{c}$ absorbs any impact of correlated unemployment rates in surrounding years. We have experimented with controlling flexibly for intervening unemployment rates and find fairly similar results. For example, following a similar specification to Oreopoulos et al. (2012), we allow each unemployment rate since college graduation to impact earnings with a quadratic decay in potential experience, but restrict adjacent unemployment rate years to have the same impact and decay pattern. With these controls, the impact of $U_{c}$ on earnings declines in magnitude by a quarter in the first year out, by a fifth in the second year out, and is otherwise very similar. Furthermore the impact of $U_{c}$ on earnings is far larger and more persistent than the impact of unemployment rates at 1 and 2 years of potential experience.

${ }^{43}$ The CPS regressions, of course, do not include college major variables. Each potential experiencegraduation cohort cell is given equal weight to simulate the two-step estimation procedure we use in the main sample. We impute division at time of college graduation with current division of residence and define
} 
-0.07 (0.016) loss in the first year after graduation (panel A, column 1) - but still significant at the $1 \%$ level. Furthermore, the experience profile has a more shallow decay. This results in an average effect over the first 10 years of experience of $0.022(0.01)$ log earnings loss per year, about double the magnitude in the combined sample, and significant at the $5 \%$ level.

The estimates for the two data sets bracket the results of Oreopoulos et al. (2012), who find that a 1 ppt increase in the national or provincial unemployment rate at college graduation reduces earnings by roughly $2 \%$ in the first year (or by $8 \%$ for a large recession) before fading away over the next 5 years. They lie well below Kahn's (2010) estimates. She finds an initial decline in pay rates of more than $20 \%$ for white males who graduated in the worst part of the 1981-82 recession compared to those who graduated in the nearby booms, in the U.S. Her estimates diminish over time but remain significant well past 10 years out of college.

The remainder of tables 3 and 4 gives guidance as to whether these earnings effects are driven by differences in time spent working, wage rates, occupational attainment, or some combination. Column 2 shows only modest impacts of entry conditions on the probability of being employed. In the combined sample (table 3, column2), the average impact over the first 10 years of a career is a 0.007 (0.004) decline in the probability of being employed, statistically significant at the $10 \%$ level. This is small compared to the mean probability of being employed in this sample, 0.89. The experience profile is also surprising in that we find no effect early in a career. Sampling error is probably part of the story. In the CPS, where we have consistent, large samples throughout the time period, the effect on employment is a substantial $-0.018(0.005)$ in the first year out, significant at the $1 \%$ level. This effect halves by three years out, is only significant at the $5 \%$ level, and becomes small and insignificant thereafter.

We find sizeable effects on the probability of full-time employment in both the combined sample and the CPS. In the combined sample (table 3, column 3), a worker graduating into a large recession is $0.066(0.012)$ less likely to be employed full time in the first year out of school, statistically significant at the $1 \%$ level. Compared to the mean probability of fulltime employment for this sample, 0.77 , this effect is quite substantial. It is also large enough to account for much of the first-year earnings loss. ${ }^{44}$ The effect then falls roughly in half by 3 years out but is still significant at the $1 \%$ level, before becoming small and insignificant thereafter. The CPS estimates for the full-time probability are very similar, though only about two-thirds the magnitude in the first year out.

Overall, a difficulty obtaining work hours likely drives a substantial portion of the earnings

$U_{c}$ as a weighted average of the unemployment rate in that division when the worker was 22 and 23 , with two-thirds weight on the former. Dependent variables are defined with the same restrictions as in the main sample, except that we cannot consistently observe whether a worker was enrolled, so we include all workers meeting the other criteria. Regression output underlying table 4 can be found in appendix table 3 on earnings and online appendix tables 3-6 for the other outcomes, under columns labeled (6).

${ }^{44}$ In our data, the gap in average earnings of full- and part-time workers is more than 1.0 log point. 
effects. When we restrict the sample to those working full-time (not shown) we find earnings effects that are about half the magnitude of those presented here. We can also measure hours worked in the CPS (though we cannot in many of the constituent data sets in the combined sample). There we find that even conditional on working during the year, the log of annual hours worked is 0.0358 (0.01) lower in the first year out after graduating into a large recession, significant at the $1 \%$ level (table 4, column 6). This effect does, however, dissipate rapidly.

To better understand effects on earning power, we next examine log hourly wage rates. Both the combined sample and the CPS show initial wage losses from graduating into a large recession of around $4 \%$ in the first year out (columns 4 in tables 3 and 4), significant at the $1 \%$ level. The CPS estimates are more persistent; even 10 years out the effect of $-0.014(0.008)$ is significant at the $10 \%$ level. On average over the first 10 years, the CPS shows an almost $2 \%$ wage loss per year, significant at the $1 \%$ level. The average effect in the combined sample is half that and not significant. ${ }^{45}$ Our estimates are substantially smaller in magnitude than those found by Kahn (2010), who also studies wage rates for graduates in the 1980s. Though not shown, we also find impacts of graduating into a recession are larger for this group than for our sample as a whole.

Wage rates could be impacted by entry conditions for a number of reasons. Early difficulty finding full-time employment or initial placements in lower-level or mismatched jobs could impact human capital and limit possibilities for career advancement. To understand the impact of entry conditions on occupational attainment, we exploit two occupation measures. First, as a measure of overall job quality, we categorize occupations by average earnings return. ${ }^{46}$ Second, to better understand mismatch, we use an indicator for whether a worker is in an occupation typical of that major. We define "typical" as being in one of the top 5 occupations for the major (hereafter Top5), but results are robust to varying the number of "top" occupations included. ${ }^{47}$ The sample mean of this variable is 0.37 . It is also worth noting that there is a $26 \%$ earnings return to being in a common occupation for one's major. ${ }^{48}$

\footnotetext{
${ }^{45}$ One might have expected a more persistent effect on wages than earnings due to evidence on the consequences of layoffs, which shows that employment and work hours recover fairly quickly following a layoff but wage losses persist. See, for example, Stevens (1997) and Altonji, Smith and Vidangos (2013). The timing of the layoff may also matter, as layoffs that happen during a recession have even larger negative effects (Davis and von Wachter 2014).

${ }^{46}$ Using just ACS data for full-time employed, non-enrolled college graduates aged 25-59 earning at least $\$ 500$, we regress log earnings on occupation fixed effects (using 1990 3-digit Census codes) and the same controls included in equation 1 (excluding major fixed effects, $U_{c}$, $\beta^{\text {major }}$ and their various interactions), except we control for year fixed effects so that the estimated occupation returns will be less sensitive to aggregate conditions. Thus occupation quality (the occupation fixed effect) is the average earnings return to the occupation from 2009-2012.

${ }^{47}$ This variable is defined on the same sample as the occupation earnings return measure. We classify the top 5 occupations for the whole sample period, meaning they are invariant to potential experience. See Altonji et al. (2012) for evidence on the distribution of similar measures of occupation concentration across college major by years of potential experience.

${ }^{48}$ We obtain this estimate from an earnings regression on our controls and major fixed effects (not shown). Kinsler and Pavan (2014) estimate returns to college majors accounting for the specificity of the skill learned
} 
Naturally, the Top5 measure can only be estimated in our combined sample.

Results are reported in columns 5 and 6 of table 3 and column 5 of table 4 . In both data sets, we find modest impacts of graduating into a large recession on occupation quality. In the combined data, we estimate a large 0.026 (0.0089) reduction in earnings return to the occupation in the first year out, significant at the $1 \%$ level. This coefficient is easily interpreted since the occupation earnings return is in log earnings units. Thus the effect is about one-quarter of the earnings effect and more than half the size of the wage effect, where one would expect impacts on occupation quality to be concentrated. By the third year out the coefficient is less than half the magnitude and is no longer significant. However, time spent in lower-paying occupations in the first few years out of school might impact wages years later holding occupation constant, since it might put workers on different trajectories for training and advancement. Furthermore, the CPS shows the occupation effects themselves might persist. In table 4, column 5, we estimate a smaller effect in the first year out, -0.015 (0.009), significant at the $10 \%$ level. The experience profile shows initial convergence, but then divergence back to the same magnitude and significance 10 years out.

We do not find any significant impacts on our measure of match quality (table 3, column $6)$, the probability of being in a common occupation given one's major. The effect in the first year is $-0.011(0.014)$ and averages to $-0.013(0.008)$ over 10 years. These effects are modest relative to the sample mean of 0.37 . They are also unlikely to have a large impact on earnings, given the earnings return to Top5 of $26 \%$. However, given sampling error, we cannot rule out modest-sized effects.

To sum up, for the full sample period we find that graduating into a time of high unemployment results in substantial earnings losses early in a career. The losses are driven partially by an inability to obtain work hours and partially from a loss in earning power. Results are qualitatively similar across the combined data and the CPS, though magnitudes do differ somewhat. The data sets are remarkably similar on full-time employment and wages. The probability of full-time employment is reduced initially by roughly 0.05 (taking an average of the two estimates), and by 0.013 on average per year over the first 10 years. Wages are about $4 \%$ lower in the first year and about $1.5 \%$ lower per year over the first 10 years. For employment and occupation quality, average impacts over 10 years are pretty similar across data sets, though not the time path. While employment effects are small, it is likely that a difficulty obtaining jobs in high-paying occupations can account for some of the wage and earnings losses. Point estimates on earnings effects are not quite as consistent across data sets, ranging from -0.07 to -0.12 in the first year out and -0.0135 to -0.022 averaged over 10 years. Given that both data sets have advantages and disadvantages, we choose as our preferred estimate an average of the two, roughly $10 \%$ earnings loss in the first year and

and find a significant premium for workers who work in a field related to their degree. They estimate a $30 \%$ return for science majors to working in a job related to their major, similar to what we estimate here for the full set of majors. 
$1.8 \%$ loss per year on average over the first 10 years. $^{49}$

\subsection{Changes in the Link between Entry Conditions and Outcomes}

The national unemployment rate was $9.3 \%$ in 2009 and $9.6 \%$ in 2010, 3.5 and 3.8 ppts (respectively) above the national mean over this time period. The analysis thus far implies that the outcomes for those graduating in 2009 or 2010 will be similar to those reported in panel A of tables 3 and 4, which fit the effects for a 4 ppt increase in the graduating unemployment rate. ${ }^{50}$

However, we now present evidence that the effect of a one point change in $U_{c}$ has increased in recent years, suggesting that the consequences of graduating during the Great Recession might be more severe than our basic results imply. Panel B of tables 3 and 4 reports early career outcomes for those graduating into a large recession, allowing the effects to differ for those graduating in 2004 or later. We chose this cutoff date so that the "post" period includes graduates from the Great Recession, as well as the preceding boom and subsequent recovery. ${ }^{51}$ Naturally, for this group, we can only identify impacts early in a career.

Both data sets show substantially larger, negative impacts in the first year out in the post period. For example, column 1 of table 3 shows that in the pre-2004 period, workers graduating into a large recession earned $0.076(0.0289) \log$ points less in their first year out. In contrast, the fitted impact for the same sized recession (4 ppt unemployment rate increase) is more than three times as large for those graduating on or after 2004. Three years out, the fitted impact is still double the magnitude in the post-period, compared to the pre-period.

Effects are fairly similar in the CPS (table 4, panel B). Impacts on earnings in the postperiod are double that of the pre-period at both 1 and 3 years out. In both data sets, we also see much larger, negative employment effects in the post-period that are significant at both 1 and 3 years out. Impacts on full-time employment are large, negative, and significant in both pre- and post-periods, though the data sets differ on which period was worse. Wage

\footnotetext{
${ }^{49}$ In section 2 we discussed the advantages and disadvantages of the CPS versus the combined sample. One important drawback in the CPS is an inability to date graduation. To the extent that effects on employment, full-time status, and hours are relatively temporary, this would influence effects on earnings in the early years more than wage rates.

${ }^{50}$ We have also investigated the possibility that the effect of a change is $U_{c}$ is bigger when $U_{c}$ is high, in which case the consequences of graduating during the Great Recession might be more severe than our results imply. We estimated a version of our model that allowed the coefficient $\beta_{2}$ to depend on whether $U_{c}$ is above or below its sample mean. In the CPS, the point estimates of the slope coefficients are very close for all labor market outcomes, and they are not significantly different. In the combined data set, the estimates are less precise but, if anything, the estimated effect of $U_{c}$ is smaller in a recession than in a boom (not reported). For example, in the case of earnings, the coefficient $U_{c}$ is $-0.028(.0065)$ when $U_{c}$ is above its mean and -0.035 $(.0080)$ when it is below its mean.

${ }^{51}$ Specifically, we interact all of our key explanatory variables in (1) $P E, P E^{2}, U_{c}, U_{c} P E, U_{c} P E^{2}, \beta^{m a j o r}$, $\left.\beta^{\text {major }} P E, U_{c} \beta^{\text {major }}, U_{c} \beta^{\text {major }} P E\right)$ with an indicator equaling 1 if the worker graduated in 2004 or later (plus a main effect of graduating on or after 2004). Results in this section are similar when we use 2001 or 1998 as the cutoff date. The regression coefficients underlying the results in panel B of tables 3 and 4 can be found in appendix table 3 and online appendix tables 3-7, under columns labeled (4) and (7), respectively.
} 
rates exhibit a similar pattern to earnings, though in the combined data convergence is much more rapid. Effects on occupational attainment do not present a consistent pattern.

On balance, tables 3 and 4 show that the recent period was a much more difficult time to graduate into a recession. Most effects remain worse three years after graduation, though it remains to be seen whether these larger effects will persist beyond that.

\section{Differential Effects Across College Major}

\subsection{Earnings}

Table 5 summarizes regression results on the interaction effects between $\beta^{\text {major }}$, the earnings return to the major, and the graduating unemployment rate $\left(U_{c}\right)$. In panel $\mathrm{B}$, we report the differential impact of graduating into a large recession for a high-return major $\left(\beta^{\text {major }}=1\right)$, compared to the average major $\left(\beta^{\text {major }}=0\right)$, at various experience levels. ${ }^{52}$ In panel $\mathrm{A}$, we report the main effect of $\beta^{\text {major }}$ as well the coefficient on its interaction with potential experience from a regression that omits major fixed effects (column 2 in appendix table 3 and online appendix tables 3-7). The main effect of $\beta^{\text {major }}$ for a given dependent variable provides a natural benchmark in assessing the differential impact of a large recession across college majors. We also compare the differential impact to the estimates of the effect of $U_{c}$ (the impact on the average graduate) based on the combined data sets, although we are mindful of the fact that the CPS estimates of the average effect are somewhat different. Aside from the need for data on college major, estimation of the differential effects is easier than estimation of the average effect, because it is identified primarily by variation within graduation year/division cohorts.

In the first year after graduation, the loss from graduating into a large recession is 0.055 (0.011) log points less for a high-return major. That is, a high-return major gains back nearly half the initial losses experienced by the average major (-0.12 from table 3$)$. Earnings inequality across majors thus widens by almost an additional third for those graduating into a large recession (comparing the 0.055 to the main effect of a standard deviation increase in $\beta^{\text {major }}$ on log earnings, 0.18). Over time, the differential impacts gradually diminish. On average over the first 10 years of a career, high-return majors lose 0.020 (0.006) log points less in earnings, relative to the average major graduating into a large recession. This is more than a complete offset to the main effect reported in table 3, a 0.013 log point average earnings loss.

Our results on earnings are in line with Oreopoulos et al. (2012), who also find that higher-skilled graduates face smaller, less persistent earnings losses when graduating into a recession. In fact, our point estimates imply that a major with at least a 1.2 standard

\footnotetext{
${ }^{52}$ Estimates in the table can be calculated from columns labeled (3) in appendix table 3 and online appendix tables $3-7$, by fitting $\hat{\beta}_{7} \cdot 4+\hat{\beta}_{8} P E_{i t} \cdot 4$ for the specified value of $P E_{i t}$.
} 
deviation larger $\beta^{\text {major }}$ (e.g., chemistry) will not experience a statistically significant earnings loss, even in the first year out of school. ${ }^{53}$

Figure 1 plots earnings profiles for different values of $\beta^{\text {major }}$ and $U_{c}$, for an easier comparison of outcomes. ${ }^{54}$ The blue lines show earnings for $\beta^{\text {major }}=1.5$ (electrical engineering, for example). The purple lines show earnings for $\beta^{\text {major }}=0$ (e.g., journalism). The green lines show earnings for $\beta^{\text {major }}=-1.5$ (e.g., art history and fine arts). The solid lines show earnings for those graduating in the average economy for our sample $\left(U_{c}=6.5\right)$; the dashed lines fit a 4 ppt lower $U_{c}$ (boom). Finally, the dotted lines show a 4 ppt higher $U_{c}$ (bust). The average fitted annual earnings in our sample is $\$ 92,000$.

Several interesting features stand out in this graph. First, the differences in earnings across majors are large and widen with experience. Second, entry conditions also matter. At 1 year of potential experience, one can easily see the gap in earnings across boom and bust cohorts (dashed and dotted lines, respectively) within major. The gap is largest for the low-return major (green line). Correspondingly, the time it takes to overcome this gap is longest for the low-return major. Also, it is better to graduate in a boom as a low-return major than to graduate in a bust as an average major, at least initially (the dashed green line is higher than the dotted purple line at 1 year of experience). However, it is always better to be a high-return major, regardless of entry conditions, than the average major (all the blue lines are above all the purple lines). The reason for this is that busts tend to widen inequality, pushing workers away from the mean, while booms tend to narrow inequality. Thus a high-return major graduating in a bust widens his or her advantage over the average major, while a low-return major graduating in a boom narrows his or her disadvantage.

\subsection{Other Labor Market Outcomes}

Column 2 of table 5 presents results on the probability of being employed. Panel A shows that workers with high-return majors have a small, but statistically significant, employment advantage that widens with experience; a major with a 1 standard deviation higher $\beta^{\text {major }}$ is 0.004 more likely to be employed and this advantage widens by 0.0012 each year. Panel B shows that this initial employment advantage widens substantially when graduating into a large recession. For example, the 0.0067 (0.004) impact on the employment probability in the

\footnotetext{
${ }^{53}$ We again point out that these effects subsume any impacts of economic conditions in the years surrounding college graduation, to the extent that unemployment rates are serially correlated. When we control for the stream of unemployment rates an individual faces between college graduation and the period when labor market conditions are measured, as described above, we obtain very similar results. Impacts on earnings are reduced by about $0.01 \log$ point.

${ }^{54}$ For each $U_{c}, \beta^{\text {major }}, P E$ combination, we fit $\log$ earnings for a white woman in the omitted survey, using the constants from the first stage regression and a second-stage regression with no major or graduation year fixed effects, and coefficients from our preferred specifications for $U_{c}$ and $U_{c} \beta^{\text {major }}$. The $U_{c}$ effect, its interactions with $P E$, and the main quadratic in $P E$ come from the specification in column 1 of appendix table 3. The $\beta^{\text {major }}$ main effect and $P E$ interaction are from column 2 , and the $\beta^{\text {major }}$ interaction with $U_{c}$ is from column 3. To convert to expected earnings, we take the anti-log of this plus 0.5 times the residual variance from the first stage, making the assumption that the errors are log normal.
} 
first year out implies a more than doubling of the initial gap. This effect is only marginally significant and fades quickly after the first year. On the other hand, the probability of being employed full-time (column 3) shows much larger and more persistent differential effects. From panel A, high-return majors are on average 0.051 more likely to be employed full-time, a large advantage relative to the base probability of 0.77 . This advantage gradually declines in magnitude as workers gain experience. From panel B, high-return majors graduating into a large recession experience an additional 0.015 increase in their probability of being employed full-time over the first 10 years of their career. The advantage is largest in the first year out when high-return majors increase their initial advantage by 0.03 (or 59\%), and it offsets roughly half the impact on the average major (table 3, column 3). These effects remain significant through the 7 th year.

Thus, the differential impact of graduating into a large recession on job-finding capability can partially explain why the earnings effects are muted for high-return majors. At the same time, even full-time workers experience large earnings differentials across college major. Though not shown here, we find that the earnings effects are still about half as large when we restrict the sample to full-time workers. Thus the differential earnings effects must be driven in part by a differential impact on earning power, in addition to differential impacts on the ability to obtain work hours. Indeed, column 4 shows that high-return majors graduating into a large recession also widen their advantage in hourly rates of pay. Panel A shows that a one standard deviation higher $\beta^{\text {major }}$ is associated with a $0.15 \mathrm{log}$ point higher wage rate in their first year out, with this advantage widening by 0.003 each year. Panel B shows that this initial advantage widens by $15 \%$ when graduating into a large recession, with impacts persisting for roughly as long as the earnings effect. Again, the differential impact for high-return majors offsets roughly half of the initial effect on wages for the average major graduating into a recession (table 3, column 4).

Columns 5 and 6 present results on occupational attainment. From column 5, panel A, high-return majors work in occupations that pay 0.13 log points more than the occupations of the average major. Panel B shows that this initial occupational advantage widens by 0.011 log points $(8 \%)$ for those who graduate into a large recession. This differential advantage dissipates with experience but is still significant even 7 years out of school. Thus, a substantial part of the earnings and wage effects could be driven by lower $\beta^{\text {major }}$ workers being relegated to lower quality jobs. ${ }^{55}$

\footnotetext{
${ }^{55}$ Our estimates imply that much of the earnings differential across college majors can be accounted for by differences in occupation quality. From panel A, a one standard deviation increase in $\beta^{\text {major }}$ is associated with a 0.18 increase in log earnings (column 1, panel A), as well as an increase in occupational quality of $0.13 \mathrm{log}$ earnings points (column 5, panel A). Taken at face value these estimates suggest that $71 \%$ of the earnings return to college major is associated with access to higher-paying occupations, although this is an overstatement because we did not control for college major when estimating the occupation fixed effects. Using the 171 major categories available in the ACS in a log wage equation, Altonji et al. (2012) report that among men the standard deviation of college major coefficients falls from 0.177 to 0.098 when detailed occupation controls are added. The corresponding values for women are 0.146 and 0.074 .
} 
Furthermore, while high-return majors are not more likely to be found in an occupation common to other workers in their major (column 6, panel A), they are differentially more likely to be found in a top-5 occupation when graduating into a large recession (panel B). Impacts actually become larger as workers gain experience, and are positive and significant over the first ten years on average. It could be that early difficulty finding good work impacts one's ability to "stay on track" later in a career. Low $\beta^{\text {major }}$ graduates are less successful in obtaining the types of jobs they had in mind when they chose their major, and likely experience earnings losses as a result.

On balance, table 5 shows that high-return majors increase their already strong advantage when graduating into a recession; they experience significantly milder effects along every dimension we can measure. Early on, ability or versatility serves high-return majors well in that they can find higher paying jobs with more work hours. Early struggles for low-return majors appear to stay with them since they are more likely to be mis-matched even years later.

\subsection{The Great Recession}

Panel C presents estimates in which we allow the effects to differ for those graduating before 2004 and those graduating in or around the Great Recession (2004 or later). ${ }^{56}$ In tables 3 and 4, we found that the average major took a substantially larger earnings hit when graduating in this later period. Here, we find for almost every outcome that the relative advantage of high-return majors declines compared to the pre-2004 period. From column 1, the earnings advantage for those graduating post-2004 is only half of what we would have predicted from data before 2004 and the size of the recession. Employment differentials essentially disappear, as does the differential impact on obtaining a job in a high-paying occupation, while high-return majors actually face relative disadvantages in finding full-time work. We investigate these findings further in the next section.

\subsection{Additional Results and Discussion}

We have estimated all of our results separately by gender and obtain very similar patterns. Also, our results are robust to a number of alternative measures of the skill level of the major, meaning our results are not particularly sensitive to the way we define $\beta^{\text {major }} .^{57}$

Another way of characterizing college majors that is not necessarily reflective of skill, but could be particularly relevant over the business cycle, is by the degree of occupational

\footnotetext{
${ }^{56}$ Regression coefficients underlying these estimates can be found in appendix table 3 and online appendix tables 3-7, under columns labeled (5).

${ }^{57}$ For example, we find similar results when using the average SAT math score in the major, as well as an SAT-ACT composite, with both measures obtained from the Baccalaureate and Beyond panels. Also, results are robust to using a proxy measure of the skill level required in the occupations a major typically enters into, which uses $\mathrm{O}^{*} \mathrm{NET}$ task data on critical thinking and problem solving. Details of these analyses are available upon request.
} 
concentration. Some majors typically enter into a narrower set of occupations than others. These majors might be more prone to sectoral shocks, since they have a less diverse set of options. We have explored whether the effects of graduating into a recession depend upon the occupational concentration of the major, defined as the share of graduates within a major who are in the top 5 occupations for that major. Nursing, computer programming, and civil engineering have the highest occupation concentration levels, while environmental studies, film and other arts, and other social sciences have the lowest. We find modest negative effects on earnings and wages in the first few years out for majors with higher occupation concentration graduating into a downturn, as well as large, negative, persistent impacts on the probability of being in an occupation common to one's major. This is consistent with the notion that versatility of a major is an important factor in weathering a recession. However, we find almost no correlation between average earnings return to a major and the occupation concentration of the major. Consequently, these effects cannot help explain our finding that earnings of high-return majors are less sensitive to recessions. Results for the occupational concentration measure are available upon request.

We have also investigated the impact of entry conditions on graduate educational attainment, a subject that has received little attention in the past. ${ }^{58}$ Differences in educational attainment could affect earnings outcomes by altering the composition of recent college graduates in the labor force across the business cycle. And, if many students graduating into a recession are induced to obtain further schooling, they could eventually out-earn their counterparts who graduated in better times. Table 6 contains the results of regressions for graduate education. ${ }^{59}$ We find that a large recession is associated with a small but statistically significant increase of 0.0048 in the probability of holding an advanced degree among those with at least 5 years of potential experience. And, consistent with the changes in relative opportunity cost, higher $\beta^{\text {major }}$ majors experience a small but statistically significant offsetting negative effect on advanced degree attainment when graduating into a bust. While these effects are intuitive, they are too small to substantially impact sample selection across years of potential experience. Including enrolled workers and controlling for educational attainments has little effect on the results reported above.

\footnotetext{
${ }^{58}$ Kahn (2010) shows that students graduating in the worst part of the 1981 recession obtain an additional year of graduate school, on average, relative to those graduating in the best times. Bedard and Herman (2008) examine the impact of state-level economic conditions on graduate enrollment for a sample of science and engineering majors and find counter-cyclical enrollment for males in Ph.D. programs, pro-cyclical enrollment for males in Master's programs, and largely acyclical enrollment for women. Johnson (2013) finds for a more representative sample of college graduates that graduate enrollment is counter-cyclical for women and acyclical for men.

${ }^{59}$ Due to difficulties in defining graduate education across data sets, this analysis is restricted to the ACS 2009-2012. We focus on graduates from 1976 to 2007 with at least 5 years of potential experience.
} 


\section{Differences in Demand Cyclicality Across Major}

Above, we showed that high-skilled majors are somewhat sheltered from the negative effects of graduating into a recession, relative to lower-skilled majors, but that this advantage declined in the Great Recession. Also, overall, recent college graduates fared much worse in the Great Recession than what would have been predicted from past data, given the size of the recession. Interestingly, both larger magnitude $U_{c}$ effects and the smaller magnitude $U_{c} \beta^{\text {major }}$ effects do not appear to be solely a phenomenon of the Great Recession. We obtain very similar results when we include graduates from 1998-2011 in the later period, which includes both the "dot com" boom years of the late 1990s and the 2001 recession. That is, graduates from the 2001 recession saw similar labor market impacts per unit change in $U_{c}$ as those from the Great Recession.

There are a number of potential explanations for the different pattern in the recent two recessions. First, both saw prolonged jobless recoveries, meaning unlucky recent graduates might have had to spend more time on the sidelines. This is consistent with the larger negative impact of $U_{c}$ on employment probabilities in the post-2004 period, shown in tables 3 and 4. Second, the industries impacted by recessions have varied over time. Earlier recessions tended to generate disproportionate employment losses in manufacturing and/or construction, from which college graduates as a group were likely sheltered. These industries have been important in the recent two recessions, but the "dot com" bust also saw substantial job loss in information technology, while the Great Recession saw substantial job losses almost everywhere, including high-return fields like finance. These recessions may therefore have been more costly to college graduates and in particular high-earning college graduates.

In this section we explore whether differences in demand cyclicality across college major can account for the differential impacts of entry conditions, and, whether changes in this cyclicality across majors, or, for college graduates as a whole can explain the broader-based impacts of the Great Recession. We develop a major-specific unemployment rate $\left(U_{c}^{\text {major }}\right)$ that varies over time and can proxy for major-specific labor demand conditions. The measure is based on industry-occupation-specific annual unemployment rates obtained from the March CPS, which we then aggregate to the college major level using fixed weights that reflect the occupation-industry composition of each major for workers aged 26-59. ${ }^{60}$

\footnotetext{
${ }^{60}$ The major-specific unemployment rate is a weighted average of occupation-industry-specific unemployment rates, using shares from the major-occupation-industry mapping as weights. An unemployment rate is defined as the number of unemployed people who report that their most recent job was in a given occupationindustry cell divided by this plus employment in the occupation-industry cell. We use 3-digit 1990 Census occupations and 12 "major" industry categories also based on 1990 Census codes. The major to occupationindustry cell mapping is generated for the 51 Department of Education major categories using just the ACS and NSCG samples (the largest of our data sets) for workers age 26-59. For the SIPP, we generate a crosswalk between the Department of Education majors and the SIPP majors based on the names of the majors, available in an online appendix. The demand measure for each SIPP category is the weighted average of the demand measures for the constituent Department of Education majors. The weights are based on the shares of each component Department of Education major category in our pooled data set, with SIPP excluded. The mapping and weights are computed at the national level rather than the divisional level.
} 
Figure 2 illustrates the relationship between the major-specific unemployment rates and aggregate conditions over time, plotting the average major-specific unemployment rate for three groups of college majors - those in the top $\beta^{\text {major }}$ quartile, the middle $50 \%$ of majors, and the bottom $\beta^{\text {major }}$ quartile - from 1971 to 2012, as well as the national unemployment rate. $^{61}$

We wish to highlight three qualitative patterns in this graph before moving to a regression analysis. First, for almost all of the sample period, the unemployment rate is highest for the low-earning majors (green line) and lowest for the high-earning majors (blue line). This illustrates a potential confounding factor: unemployment rates reflect both labor demand conditions and the ability to find employment given demand conditions. Below, we will estimate how the major-specific unemployment rate moves with the aggregate unemployment rate and how this varies with $\beta^{\text {major }}$. There, controls for major fixed effects will remove permanent differences across majors in the ability to find employment. However, if the importance of ability differences varies over the business cycle, then differences in the sensitivity of major-specific unemployment rates to the aggregate unemployment rate are not a clean measure of major-specific differences in labor demand cyclicality. Hence this analysis should be taken with a grain of salt. ${ }^{62}$

Second, all lines exhibit the same cyclical pattern, but, for much of the period, the amplitudes are quite different. The national unemployment rate (yellow dashed line) tends to have larger increases in recessions and decreases in booms than any of the major-specific unemployment rates, reflecting the fact that the labor market for college graduates is overall less cyclical. Also, for much of the period, there is an analogous pattern across major-specific unemployment rates, with the lower $\beta^{\text {major }}$ groups experiencing higher amplifications. This suggests that lower $\beta^{\text {major }}$ majors tend to be found in jobs that are more cyclically sensitive.

Third, these cyclical patterns changed dramatically in the last decade. The size of the run up and run down of the unemployment rate surrounding both the 2001 recession and the Great Recession look very similar across groups of majors and more similar to the national unemployment rate. This suggests that labor demand for jobs that high-return majors tend to go into, and the market for college graduates as a whole, has become more cyclically sensitive.

We now quantify the relationship between the major-specific unemployment rates and aggregate economic conditions by regressing $U_{c}^{\text {major }}$ on the divisional value of $U_{c}, \beta^{\text {major }}$ and $\beta^{\text {major }} * U_{c}$, plus a cubic time trend. Column 1 of table 7 reports this regression over the time

\footnotetext{
${ }^{61}$ These reflect unweighted averages of major-specific national unemployment rates in a given year. Division unemployment rates look similar but noisier.

${ }^{62}$ We have also explored a major-specific employment growth measure to better isolate the labor demand component from the adaptability of workers in a major. The results described below are similar when using this measure. However, the link between the change in employment and the level of employment demand may be more tenuous, which is why we prefer the unemployment rate. We do not use major-specific employment levels because the link between this measure and the aggregate unemployment rate is highly sensitive to how we detrend it.
} 
period 1971-2012, where an observation is a major-division-year. The coefficient on $U_{c}$ is 0.25 (0.0173), which says that the unemployment rate for college graduates fluctuates only about one fourth as much as that of the whole labor market. The coefficient on $\beta^{\text {major }}$ is negative and significant, meaning that higher-skilled majors are less likely to be unemployed. The interaction term of $-0.026(0.004)$ on $\beta^{\text {major }} * U_{c}$ indicates that when aggregate unemployment rises, labor demand conditions deteriorate less for higher-earning majors, and also possibly that higher-earning majors adapt better to demand conditions. ${ }^{63}$

The fact that demand for high-skilled majors is less sensitive to the business cycle could help account for the widening earnings advantage of high-skilled majors in recessions compared to booms. However, given the very small magnitude of the interaction effect on major-specific unemployment $(-0.026)$, relative to the overall impact of the unemployment rate $(0.25)$, one would not expect the measure to explain much of the earnings differentials. ${ }^{64}$

Columns 3 and 4 investigate whether these relationships changed in the period surrounding the Great Recession. They report estimates of the same regression for 1971-2003 and for 2004-2011, respectively. We also control for a cubic time trend over the 1971-2003 period, but this makes little difference (compare columns 2 and 3). The main effect of $U_{c}$ increases from $0.200(0.0175)$ in the earlier period to 0.508 (0.0277) in the later period, a factor of 2.5. That is, the labor market for college graduates became much more correlated with aggregate market conditions. This is reflected in the figure, which shows that the run up in majorspecific unemployment in the Great Recession was very similar to that for the national rate. This could easily explain why the negative effects of entry conditions were much larger in magnitude for graduates from 2004 onwards.

The coefficient on $\beta^{\text {major }} * U_{c}$ declines in magnitude from -0.0344 (0.0039) for 1971-2003 to -0.0126 (0.0057), indicating the cyclicality of demand for higher-skilled majors has increased relative to the average major. For 1971-2003, demand for higher-skilled majors was $17.2 \%$ less cyclically sensitive than for the average major. It declined to $2.5 \%$ for the recent period. This may in part explain the reduced advantage for high-skilled majors graduating into the Great Recession, compared to the earlier period. But since estimated differences in the cyclicality of $U_{c}^{\text {major }}$ were relatively small even in the earlier period, the decline is probably not the whole explanation.

\section{Conclusion}

In this paper we measure the labor market consequences of graduating from college in times of higher unemployment and study how those consequences vary with the skill level of one's

\footnotetext{
${ }^{63}$ We obtain similar results when we use national-level unemployment rates and an observation is a majoryear (not shown).

${ }^{64}$ When we add controls for $U_{c}^{\text {major }}$ and its interaction with $P E$ to the regressions underlying table 5, we find almost no change to the coefficients governing the differential effects of entry conditions across $\beta^{m a j o r}$.
} 
college major. Most of the analysis pools information on the graduating classes of 19742011. However, we also examine whether labor market conditions matter more for recent college classes, which include those from the Great Recession. We use both the CPS and a "combined" data set that pools information from seven distinct surveys to provide the most comprehensive analysis of the effects of entry conditions on college graduates to date. Given that the nature of economic fluctuations varies, the long time period we work with brings substantial added value to this question, as does our analysis across fields of study, which has received little attention in the literature.

We find that early careers are disrupted by poor labor market conditions. For college graduates on average, we estimate that earnings decline by roughly $10 \%$ in the first year out after graduating into a large recession, and by about $1.8 \%$ per year on average over the first 10 years. These effects mostly fade out over the first seven years of a career. They are driven by short-term negative effects on the employment rate and especially the fulltime employment rate, as well as somewhat more persistent effects on wage rates. A shift to lower-paying occupations accounts for a substantial fraction of the initial wage loss, although the CPS and the combined data differ on the persistence of this occupational downgrading effect.

We also find that the early careers of higher-skilled majors (as measured by the earnings premium) are less sensitive to aggregate conditions at graduation. In other words, the earnings gap across college majors widens in recessions. A person in a typically high-earning major increases his or her earnings advantage by almost a third when graduating into a severe recession, relative to an average major, and this effect remains large for the first seven years after college graduation. These differential effects reflect increases in the probability of employment and full-time employment for higher-skilled majors relative to lower-skilled majors graduating into a recession, as well as differential effects on wage rates and occupational attainment.

We investigate the extent to which differences in labor demand cyclicality across college major can account for the differential effects of entry conditions. While we do find that the unemployment rates of higher paying majors are less sensitive to the business cycle, the differences in sensitivity are too small to account for the differential impacts on earnings. It could instead be that since lower-skilled majors spend more of their early experience years out of full-time employment, they suffer more from hysteresis, due for example to skill depreciation. We had expected lower-skilled majors to be less sensitive to this depreciation, but evidence suggests that there are in general large penalties for time spent out of work (Kroft et al. (2013), Bertrand et al. (2010)). Oreopoulos et al. (2012) posited that higherskilled majors can more easily recover from early setbacks because of more productive job search. This seems unlikely in our setting, however, since the largest differential effects are concentrated in the years just after graduation.

Effects on occupation quality and match quality may be able to account for some of the 
differential earnings and wage effects across majors. High-skilled majors graduating into a recession are relatively more likely to be in occupations that are both higher paying and more typical for their major, compared to lower-skilled majors. The occupation quality differentials fade out over the first 10 years of a career, but the match quality effects persist. This suggests that an initial ability to obtain quality work hours serves high-skilled majors well, prevents any negative impacts of early time spent out of full-time employment, and leaves them better set up to be in jobs that are a good fit even years later. Though earnings and wage differentials due to entry conditions do not persist across college majors, persistent differences in the ability to attain a job one likely had in mind when choosing his or her major could result in persistent differences in job satisfaction and well-being.

Overall, our results for the 1974-2011 time span fit well with the previous literature. They are quite consistent with Oreopoulos et al. (2012), who study labor market shocks in Canada and find modest earnings effects of graduating in a recession that persist for a few years and are smaller in magnitude for higher-skilled majors. Our estimates of wage effects for the average major are smaller in both magnitude and persistence, compared with Kahn's (2010) analysis of the 1981-82 recession. Besides studying a broader set of demographic groups (Kahn restricts her analysis to white males) we also study college graduates from a much longer range of years. Concerning educational attainment, our finding that those graduating into a recession are slightly more likely to obtain an advanced degree is consistent with Kahn and broadly consistent with the small literature on the cyclicality of graduate enrollment rates (Bedard and Herman (2008), Johnson (2013)). Again, we provide evidence for a larger range of graduation years and by college major.

We find effects on earnings are substantially more negative for graduates from the Great Recession. The per unit effect of an increase in the aggregate unemployment rate for graduates from 2004-2011 one year after graduation is between 2 and 3 times the value for graduates from 1974-2003. A substantial part of this increase is probably explained by the fact that the unemployment rates of college graduates as whole became much more sensitive to aggregate economic conditions in the years surrounding the Great Recession.

We also find that the effects of economic conditions have become much more evenly distributed across college major. It looks as though the "modern recession" is more broadbased, impacting recent college graduates and higher-skilled majors to a greater extent than previous recessions. The two most recent recessions may then have leveled the playing field to some degree across education groups and within college graduates; that is, college graduates bore something closer to their "fair share", relative to non-college workers, and the same was true for high-earning majors relative to low-earnings majors. Further work is needed on the types of shocks that lead to persistent (and differential) impacts on recent college graduates. This may yield a better understanding of the nature of recessions and recoveries of the last two decades. 


\section{References}

[1] Altonji, Joseph G. (1993). "The Demand for and Return to Education When Education Outcomes are Uncertain," Journal of Labor Economics, Volume 11, No. 1. 48-83.

[2] Altonji, Joseph G., Erica Blom, and Costas Meghir (2012) "Heterogeneity in Human Capital Investments: High School Curriculum, College Major, and Careers," Annual Review of Economics, Volume 4. 185-223.

[3] Altonji, Joseph G., Lisa B. Kahn, and Jamin D. Speer (2014) "Trends in Earnings Differentials Across College Majors and the Changing Task Composition of Jobs," American Economic Review, Papers and Proceedings, Volume 104, No. 5. 387-393.

[4] Altonji, Joseph G., Anthony A. Smith, and Ivan Vidangos (2013) "Modeling Earnings Dynamics," Econometrica, 81(1): 1395-1454.

[5] Arcidiacono, Peter (2004) "Ability Sorting and the Returns to College Major," Journal of Econometrics, Volume 121, No. 1-2. 343-375.

[6] Baker, George, Michael Gibbs, and Bengt Holmstrom (1994) "The Wage Policy of a Firm," Quarterly Journal of Economics, Volume 109, No. 4. 921-955.

[7] Beaudry, Paul, and John DiNardo (1991) "The Effect of Implicit Contracts on the Movement of Wages Over the Business Cycle: Evidence from Micro Data," Journal of Political Economy, Volume 99, No. 4. 665-688.

[8] Bedard, Kelly, and D.A. Herman (2008) "Who Goes to Graduate/Professional School? The Importance of Economic Fluctuations, Undergraduate Field, and Ability," Economics of Education Review, 27, 197-210.

[9] Bertrand, Marianne, Claudia Goldin, and Lawrence F. Katz (2010) "Dynamics of the Gender Gap for Young Professionals in the Financial and Corporate Sectors," American Economic Journal: Applied Economics, Volume 2, No. 3. 228-255.

[10] Bils, Mark, and Kenneth J. McLaughlin (2001) "Interindustry Mobility and the Cyclical Upgrading of Labor," Journal of Labor Economics, Volume 19, No. 1. 94-135.

[11] Blom, Erica (2012) "Labor Market Determinants of College Major," Mimeo, Yale University.

[12] Card, David and Thomas Lemieux (2001) "Dropout and enrollment trends in the postwar period: What went wrong in the 1970s?" in J. Gruber (Ed.), Risky Behavior Among Youths: An Economic Analysis (pp. 439-482). Chicago: The University of Chicago Press. 
[13] Davis, Steven J., and Till von Wachter (2014) "Recessions and the Cost of Job Loss," Brookings Papers on Economic Activity, April.

[14] Devereux, Paul (2002) "Occupational Upgrading and the Business Cycle," Labour, Volume 16, No. 3. 423-452.

[15] Gibbons, Robert, and Michael Waldman (2006) "Enriching a Theory of Wage and Promotion Dynamics Inside Firms," Journal of Labor Economics, Volume 24, No. 1. 203207.

[16] Hershbein, Brad J. (2012) "Graduating High School in a Recession: Work, Education, and Home Production," The B.E. Journal of Economic Analysis \& Policy, Volume 12, No. 1, Article 3 .

[17] Johnson, Matthew T. (2013) "The impact of business cycle fluctuations on graduate school enrollment", Economics of Education Review, Volume 34. 122-134.

[18] Kahn, Lisa B. (2010) "The Long-Term Labor Market Consequences of Graduating from College in a Bad Economy," Labour Economics, Vol. 17, No. 2. 303-316.

[19] Kinsler, Josh, and Ronni Pavan (2014) "The Specificity of General Human Capital: Evidence from College Major Choice," Forthcoming, Journal of Labor Economics.

[20] Kondo, Ayako (2008) "Differential Effects of Graduating During Recessions Across Race and Gender," Mimeo.

[21] Kroft, Kory, Fabian Lange, and Matthew Notowidigdo (2013) "Duration Dependence and Labor Market Conditions: Evidence from a Field Experiment," Quarterly Journal of Economics, Volume 128, No. 3. 1123-1167.

[22] Liu, Kai, Kjell G. Salvanes, and Erik O. Sorensen (2012) "Good Skills in Bad Times: Cyclical Skill Mismatch and the Long-Term Effects of Graduating in a Recession," IZA Discussion Paper No. 6820.

[23] Murphy, Kevin M., and Robert H. Topel (2002) "Estimation and Inference in Two-step Econometric Models," Journal of Business \& Economic Statistics, Volume 20, No. 1. 88-97.

[24] Oreopoulos, Philip, Till von Wachter, and Andrew Heisz (2012) "Short and Long-Term Career Effects of Graduating in a Recession." American Economic Journal: Applied Economics, Volume 4, No. 1. 1-29.

[25] Oyer, Paul (2006) "Initial Labor Market Conditions and Long-Term Outcomes for Economists," Journal of Economic Perspectives, 20. 143-160. 
[26] Oyer, Paul (2008) "The Making of an Investment Banker: Macroeconomic Shocks, Career Choice, and Lifetime Income," The Journal of Finance, 63. 2601-2628.

[27] Shimer, Robert (2004) "Search Intensity," Mimeo.

[28] Stevens, Ann Huff (1997) "Persistent Effects of Job Displacement: The Importance of Multiple Job Losses," Journal of Labor Economics, Volume 15, No. 1. 165-188.

[29] Topel, Robert, and Michael P. Ward (1992) "Job Mobility and the Careers of Young Men," Quarterly Journal of Economics, Volume 107, No. 2. 439-79.

[30] Turner, Sarah E., and William G. Bowen (1999) "Choice of Major: The Changing (Unchanging) Gender Gap," Industrial and Labor Relations Review, Volume 52, No. 2. 289-313.

[31] Wozniak, Abigail (2010) "Are College Graduates More Responsive to Distant Labor Market Opportunities?" Journal of Human Resources Volume 45, No. 4. 944-970. 


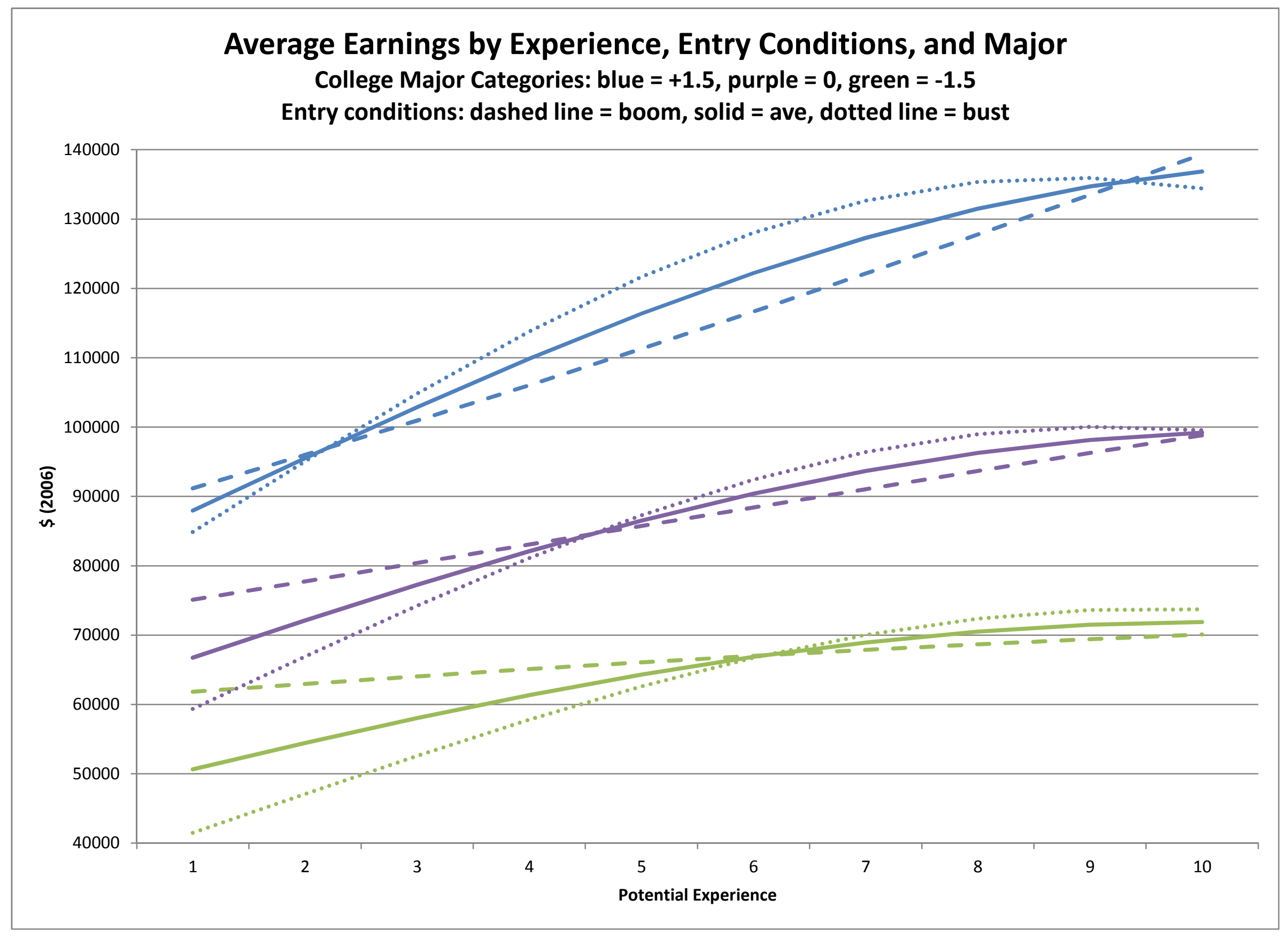


Figure 2: Major-specific unemployment rates

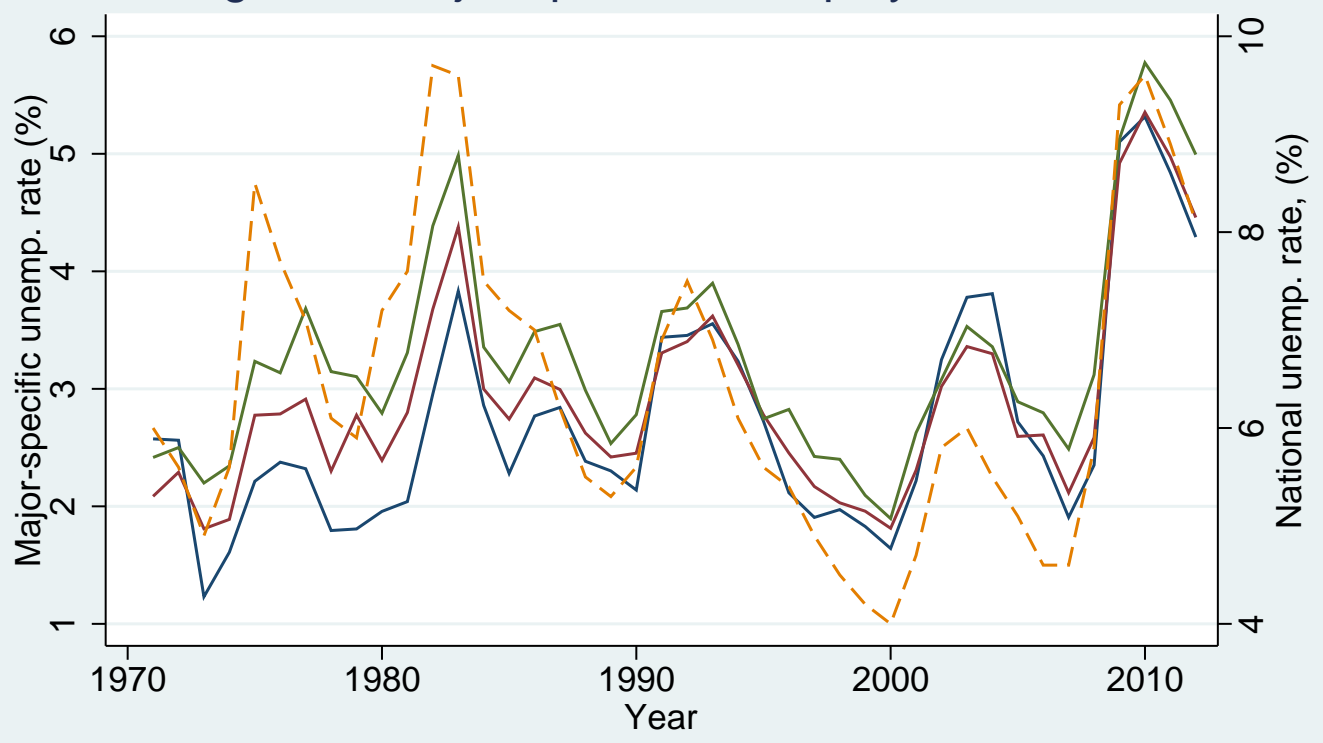

Top quartile of majors 33 Middle $50 \%$ of majors Bottom quartile of majors National unemp rate 
Table 1: Summary Statistics for Combined Earnings Sample with Equal Weighting across Graduation Year-Potential Experience-Division Cells

\begin{tabular}{|c|c|c|c|c|c|}
\hline Variable & $\mathrm{n}$ & Mean & St Dev & Min & Max \\
\hline Male & 537,458 & 0.49 & 0.50 & 0 & 1 \\
\hline Black & 537,390 & 0.06 & 0.24 & 0 & 1 \\
\hline Hispanic & 537,390 & 0.03 & 0.18 & 0 & 1 \\
\hline Potential experience & 537,465 & 6.86 & 3.59 & 1 & 13 \\
\hline Graduation year & 537,465 & 1989.99 & 9.38 & 1974 & 2011 \\
\hline Graduation unemployment rate (division) (\%) & 537,368 & 6.27 & 1.79 & 2.8 & 12.5 \\
\hline Year & 537,465 & 1996.83 & 9.62 & 1977 & 2012 \\
\hline Annual earnings (2006 \$) & 537,465 & 47,180 & 33,395 & 500 & $400,000 *$ \\
\hline Log annual earnings & 537,465 & 10.53 & 0.76 & 6.22 & 12.90 \\
\hline Full-time & 535,407 & 0.87 & 0.31 & 0 & 1 \\
\hline Employed & 535,046 & 0.96 & 0.17 & 0 & 1 \\
\hline Occupation log earnings return & 519,382 & -0.06 & 0.33 & -1.60 & 0.81 \\
\hline In top 5 most common occupations for major & 519,382 & 0.37 & 0.47 & 0 & 1 \\
\hline$\beta^{\text {major }}$ & 537,465 & -0.03 & 0.83 & -2.59 & 1.89 \\
\hline Highest grade completed & 537,454 & 16.44 & 0.94 & 16 & 20 \\
\hline \multicolumn{6}{|c|}{ Summary Statistics for Relevant Samples } \\
\hline Employed & 673,998 & 0.89 & 0.30 & 0 & 1 \\
\hline Full-time & 671,343 & 0.77 & 0.40 & 0 & 1 \\
\hline
\end{tabular}

Notes: The sample is the combined data set described in the text. The primary sample (top panel) includes nonenrolled workers age 22-35 with potential experience 1 to 13 with a valid annual earnings observation (greater than \$500 in 2006 dollars). The regression samples for employed and full-time (bottom panel) exclude enrolled workers but have no restriction on earnings, and also include those with potential experience equal to zero.

*Topcoded 
Table 2: Earnings Premiums for Department of Education Major Categories

\begin{tabular}{l|l|l|c}
\hline Major: & $\beta^{\text {major }}$ & Major: & $\beta^{\text {major }}$ \\
\hline Chemical Engineering & 1.90 & Earth and Other Physical Sci & 0.07 \\
Electrical Engineering & 1.48 & Engineering Tech & 0.04 \\
Finance & 1.42 & Journalism & -0.03 \\
Economics & 1.40 & History & -0.13 \\
Mechanical Engineering & 1.29 & Architecture & -0.15 \\
Chemistry & 1.27 & Communications & -0.25 \\
All Other Engineering & 1.09 & Public Health & -0.41 \\
Biological Sciences & 1.08 & Protective Services & -0.47 \\
Computer and Info Tech & 1.03 & Letters: Lit, Writing, Other & -0.65 \\
Civil Engineering & 1.01 & Psychology & -0.66 \\
Accounting & 1.01 & Environmental Studies & -0.69 \\
Nursing & 0.93 & Foreign Language & -0.72 \\
Political Science & 0.77 & Leisure Studies and Basic Skills & -0.74 \\
Computer Programming & 0.74 & Other Social Science & -0.79 \\
Mathematics & 0.71 & Fitness and Nutrition & -0.94 \\
Physics & 0.69 & Agriculture and Agr. Science & -1.00 \\
Marketing & 0.63 & Commercial Art and Design & -1.07 \\
International Relations & 0.63 & Social Work \& Human Resource & -1.15 \\
Other Med/Health Services & 0.62 & Family and Consumer Science & -1.25 \\
Misc. Business and Med. Suppor & 0.49 & Secondary Education & -1.37 \\
Medical Tech & 0.48 & Library Science and Education & -1.46 \\
Precision Prod. \& Industrial Arts & 0.39 & Art History and Fine Arts & -1.48 \\
Business Mgmt and Admin & 0.23 & Film and Other Arts & -1.71 \\
Multidisciplinary or General Sci & 0.13 & Music and Speech/Drama & -1.79 \\
Public Administration and Law & 0.12 & Philosophy and Religion & -2.32 \\
Area, Ethnic, and Civ. Studies & 0.10 & & \\
\hline
\end{tabular}

Notes: $\beta^{\text {major }}$ is the earnings return to the major, based on authors' calculations, given in standard deviations. See the text for details on how this is calculated. Major categories differ in each data set we use and are crosswalked to these

Department of Education categories by the authors, based on the names and/or descriptions of the majors. 
Table 3: Effect of 4-ppt Rise in Graduation Unemployment Rate

\begin{tabular}{|c|c|c|c|c|c|c|c|c|c|c|c|c|}
\hline & \multicolumn{8}{|c|}{ Employment: } & \multicolumn{4}{|c|}{ Occupation Variables: } \\
\hline & \multicolumn{2}{|c|}{$\log$ (Earnings) } & \multicolumn{2}{|c|}{$\operatorname{Pr}($ Employed) } & \multicolumn{2}{|c|}{ Pr(Full time) } & \multicolumn{2}{|c|}{$\log ($ Wages $)$} & \multicolumn{2}{|c|}{ Earnings Return } & \multicolumn{2}{|c|}{$\operatorname{Pr}($ in top 5 occ) } \\
\hline & \multicolumn{2}{|c|}{ (1) } & \multicolumn{2}{|c|}{$(2)$} & \multicolumn{2}{|c|}{ (3) } & \multicolumn{2}{|c|}{ (4) } & \multicolumn{2}{|c|}{ (5) } & \multicolumn{2}{|c|}{ (6) } \\
\hline & \multicolumn{12}{|c|}{ Panel A: All Graduation Cohorts, 1974-2011 } \\
\hline $\begin{array}{l}\text { Avg. effect for } \\
\text { potexp } 1 \text { to } 10 \\
\text { (s.e.) }\end{array}$ & \multicolumn{2}{|c|}{$\begin{array}{l}-0.0135 \\
(0.0107)\end{array}$} & \multicolumn{2}{|c|}{$\begin{array}{c}-0.0074 * \\
(0.0041)\end{array}$} & \multicolumn{2}{|c|}{$\begin{array}{c}-0.0154 * * * \\
(0.0058)\end{array}$} & \multicolumn{2}{|c|}{$\begin{array}{l}-0.0096 \\
(0.0081)\end{array}$} & \multicolumn{2}{|c|}{$\begin{array}{l}-0.0036 \\
(0.0055)\end{array}$} & \multicolumn{2}{|c|}{$\begin{array}{l}-0.0131 \\
(0.0081)\end{array}$} \\
\hline \multicolumn{13}{|l|}{ At potexp = } \\
\hline 1 & \multirow{2}{*}{\multicolumn{2}{|c|}{$\begin{array}{c}-0.1177 * * * \\
(0.0239)\end{array}$}} & \multirow{2}{*}{\multicolumn{2}{|c|}{$\begin{array}{c}-0.0046 \\
(0.0065)\end{array}$}} & \multirow{2}{*}{\multicolumn{2}{|c|}{$\begin{array}{c}-0.0664 * * * \\
(0.0119)\end{array}$}} & \multirow{2}{*}{\multicolumn{2}{|c|}{$\begin{array}{c}-0.0425 * * * \\
(0.0197)\end{array}$}} & \multirow{2}{*}{\multicolumn{2}{|c|}{$\begin{array}{c}-0.0264 * * * \\
(0.0089)\end{array}$}} & \multicolumn{2}{|c|}{-0.0110} \\
\hline & & & & & & & & & & & $(0.0$ & 136) \\
\hline 3 & \multirow{2}{*}{\multicolumn{2}{|c|}{$\begin{array}{c}-0.0400 * * * \\
(0.0141)\end{array}$}} & \multirow{2}{*}{\multicolumn{2}{|c|}{$\begin{array}{l}-0.0036 \\
(0.0047)\end{array}$}} & \multirow{2}{*}{\multicolumn{2}{|c|}{$\begin{array}{c}-0.0275^{* * *} \\
(0.0071)\end{array}$}} & \multirow{2}{*}{\multicolumn{2}{|c|}{$\begin{array}{l}-0.0146 \\
(0.0111)\end{array}$}} & -0.0 & 0096 & -0.0 & 138 \\
\hline & & & & & & & & & $(0.0$ & 064) & $(0.0$ & 998) \\
\hline 7 & 0.02 & $85^{* *}$ & -0. & 0079 & 0.00 & 054 & 0.0 & 045 & 0.0 & 055 & -0.0 & 142 \\
\hline & $(0.0$ & 142) & $(0.0$ & 055) & $(0.00$ & 081) & $(0.0$ & 109) & $(0.0$ & 067) & $(0.0$ & 101) \\
\hline 10 & 0.0 & 037 & -0.01 & $65^{* * *}$ & -0.0 & 094 & -0.0 & 0133 & 0.0 & 007 & -0.0 & 099 \\
\hline & $(0.0$ & 126) & $(0.0$ & 052) & $(0.0$ & 04) & $(0.0$ & 107) & $(0.0$ & 058) & $(0.0$ & 998) \\
\hline & & & & Panel B: & Pre-2004 G & rraduation & Cohorts ve & ersus 2004 & and After & & & \\
\hline & Pre & Post & Pre & Post & Pre & Post & Pre & Post & Pre & Post & Pre & Post \\
\hline At potexp = & & & & & & & & & & & & \\
\hline 1 & $-0.0757 * * *$ & $-0.2435 * * *$ & 0.0057 & $-0.0124 *$ & $-0.0752 * * *$ & $-0.0387 * * *$ & -0.0343 & $-0.1051 * * *$ & $-0.0241^{* *}$ & $-0.0335 * * *$ & -0.0263 & 0.0118 \\
\hline & $(0.0289)$ & $(0.0246)$ & $(0.0096)$ & $(0.0074)$ & $(0.0170)$ & $(0.0114)$ & $(0.0260)$ & $(0.0182)$ & (0.0119) & $(0.0084)$ & $(0.0183)$ & $(0.0159)$ \\
\hline 3 & -0.0130 & -0.0232 & 0.0033 & $-0.0111^{* *}$ & $-0.0268 * * *$ & $-0.0381^{* * * *}$ & -0.0120 & -0.0036 & -0.0078 & 0.0009 & $-0.0222 *$ & $0.0240 * *$ \\
\hline & $(0.0164)$ & $(0.0216)$ & $(0.0063)$ & $(0.0049)$ & (0.0095) & $(0.0084)$ & $(0.0143)$ & (0.0148) & $(0.0081)$ & $(0.0101)$ & $(0.0126)$ & (0.0115) \\
\hline
\end{tabular}

$* * * \mathrm{p}<0.01, * * \mathrm{p}<0.05, * \mathrm{p}<0.1$

Notes: The sample is the combined data set described in the text. Observations are major-gradyear-division-potexp cells, weighted by the major's share within division-gradyear-potexp (potexp = years since graduation). Columns 2 and 3 include those age 22-35, not enrolled, with 0 to 13 years potexp. Columns 1 , and 4-6 additionally exclude workers without earnings and those with 0 years potexp. The graduation unemployment rate is the divisional unemployment rate in the year of college graduation. We also control for survey, major, gender-by-race, and division fixed effects, a cubic time trend, a quadratic in potexp interacted with gender, and the earnings return to the major interacted with: the graduating unemployment rate, potential experience, and the product of the two. For Panel B, we also include an indicator for whether the person graduated in or after 2004 and the interactions of the post-2004 indicator with the quadratic in potexp, the graduation unemployment rate ( $\mathrm{U}$ ), Uc*potexp, $\mathrm{U}_{\mathrm{c}}{ }^{*}$ potexp ${ }^{2}$ the earnings return to the major and with all of the interaction terms involving the earnings return to the major. 
Table 4: Effect of 4-ppt Rise in Graduation Unemployment Rate (March CPS, 1976 to 2012)

\begin{tabular}{|c|c|c|c|c|c|c|c|c|c|c|c|c|}
\hline & \multicolumn{8}{|c|}{ Employment: } & & & & \\
\hline & \multicolumn{2}{|c|}{ Log earnings } & \multicolumn{2}{|c|}{ Pr(Employed) } & \multicolumn{2}{|c|}{ Pr(Full time) } & \multicolumn{2}{|c|}{ Log wages } & \multicolumn{2}{|c|}{ Occ Earnings } & \multicolumn{2}{|c|}{ Log hours last year } \\
\hline & \multicolumn{2}{|c|}{ (1) } & \multicolumn{2}{|c|}{ (2) } & \multicolumn{2}{|c|}{ (3) } & \multicolumn{2}{|c|}{ (4) } & \multicolumn{2}{|c|}{ (5) } & \multicolumn{2}{|c|}{ (6) } \\
\hline & \multicolumn{12}{|c|}{ Panel A: All Graduation Cohorts, 1975-2011 } \\
\hline $\begin{array}{c}\text { Avg. effect for } \\
\text { potexp } 1 \text { to } 10 \\
\text { (s.e.) } \\
\text { At potexp }=\end{array}$ & \multicolumn{2}{|c|}{$\begin{array}{c}-0.0224 * * \\
(0.0097)\end{array}$} & \multicolumn{2}{|c|}{$\begin{array}{c}-0.0062 * * \\
(0.0032)\end{array}$} & \multicolumn{2}{|c|}{$\begin{array}{c}-0.0114 * * \\
(0.0047)\end{array}$} & \multicolumn{2}{|c|}{$\begin{array}{c}-0.0197 * * * \\
(0.0063)\end{array}$} & \multicolumn{2}{|c|}{$\begin{array}{l}-0.0071 \\
(0.0049)\end{array}$} & \multicolumn{2}{|c|}{$\begin{array}{l}-0.0017 \\
(0.0058)\end{array}$} \\
\hline 1 & \multicolumn{2}{|c|}{$\begin{array}{c}-0.0696 * * * \\
(0.0158)\end{array}$} & \multicolumn{2}{|c|}{$\begin{array}{c}-0.0182 * * * \\
(0.0052)\end{array}$} & \multicolumn{2}{|c|}{$\begin{array}{c}-0.0442 * * * \\
(0.0079)\end{array}$} & \multicolumn{2}{|c|}{$\begin{array}{c}-0.0342 * * * \\
(0.0097)\end{array}$} & \multicolumn{2}{|c|}{$\begin{array}{c}-0.0146 * \\
(0.0088)\end{array}$} & \multicolumn{2}{|c|}{$\begin{array}{c}-0.0358^{* * *} \\
(0.0102)\end{array}$} \\
\hline 3 & \multicolumn{2}{|c|}{$\begin{array}{c}-0.0343^{* * *} \\
(0.0116)\end{array}$} & \multicolumn{2}{|c|}{$\begin{array}{c}-0.0087^{* *} \\
(0.0034)\end{array}$} & \multicolumn{2}{|c|}{$\begin{array}{c}-0.0220^{* * *} \\
(0.0051)\end{array}$} & \multicolumn{2}{|c|}{$\begin{array}{c}-0.0246 * * * \\
(0.0077)\end{array}$} & \multicolumn{2}{|c|}{$\begin{array}{l}-0.0068 \\
(0.0056)\end{array}$} & \multicolumn{2}{|c|}{$\begin{array}{c}-0.0087 \\
(0.0073)\end{array}$} \\
\hline 7 & \multicolumn{2}{|c|}{$\begin{array}{l}-0.0034 \\
(0.0120)\end{array}$} & \multicolumn{2}{|c|}{$\begin{array}{l}-0.0012 \\
(0.0044)\end{array}$} & \multicolumn{2}{|c|}{$\begin{array}{c}0.0013 \\
(0.0065)\end{array}$} & \multicolumn{2}{|c|}{$\begin{array}{l}-0.0142 * \\
(0.0079)\end{array}$} & $\begin{array}{l}-0.0 \\
(0.0\end{array}$ & $\begin{array}{l}037 \\
064)\end{array}$ & $\begin{array}{l}0.01 \\
(0.0\end{array}$ & $\begin{array}{l}24^{*} \\
072)\end{array}$ \\
\hline 10 & $\begin{array}{l}-0.0 \\
(0.0 \\
\end{array}$ & $\begin{array}{l}0149 \\
124) \\
\end{array}$ & $\begin{array}{l}-0.0 \\
(0.0\end{array}$ & $\begin{array}{l}0059 \\
043) \\
\end{array}$ & $\begin{array}{r}0.00 \\
(0.00 \\
\end{array}$ & $\begin{array}{l}003 \\
57) \\
\end{array}$ & $\begin{array}{l}-0.01 \\
(0.00\end{array}$ & $\begin{array}{l}141^{*} \\
081)\end{array}$ & $\begin{array}{r}-0.0 \\
(0.0 \\
\end{array}$ & $\begin{array}{l}120 * * \\
050)\end{array}$ & $\begin{array}{l}-0.0 \\
(0.0\end{array}$ & $\begin{array}{l}007 \\
076)\end{array}$ \\
\hline 12 & & $\begin{array}{c}-0.0805^{* *} \\
-0.0382 \\
\end{array}$ & & & & & & \begin{tabular}{|c|}
$-0.0769 *$ \\
-0.0383 \\
\end{tabular} & & $\begin{array}{c}-0.0268 * \\
-0.0141\end{array}$ & & \\
\hline & & & & Panel B: & Pre-2004 G & raduation & Cohorts ver & rsus 2004 a & nd After & & & \\
\hline & Pre & Post & Pre & Post & Pre & Post & Pre & Post & Pre & Post & Pre & Post \\
\hline 1 & $\begin{array}{c}-0.0467 * * \\
(0.0193)\end{array}$ & $\begin{array}{c}-0.0894 * * * \\
(0.0258)\end{array}$ & $\begin{array}{c}-0.0170^{* *} \\
(0.0065)\end{array}$ & $\begin{array}{c}-0.0321 * * * \\
(0.0093)\end{array}$ & $\begin{array}{c}-0.0423 * * * \\
(0.0093)\end{array}$ & $\begin{array}{c}-0.0517 * * * \\
(0.0144)\end{array}$ & $\begin{array}{c}-0.0291 * * \\
(0.0113)\end{array}$ & $\begin{array}{c}-0.0563^{* * *} \\
(0.0195)\end{array}$ & $\begin{array}{l}-0.0083 \\
(0.0112)\end{array}$ & $\begin{array}{l}-0.0169 \\
(0.0132)\end{array}$ & $\begin{array}{l}-0.0210 \\
(0.0128)\end{array}$ & $\begin{array}{l}-0.0252 * \\
(0.0135)\end{array}$ \\
\hline 3 & $\begin{array}{l}-0.0214 \\
(0.0132)\end{array}$ & $\begin{array}{c}-0.0566^{*} \\
(0.0293)\end{array}$ & $\begin{array}{l}-0.0057 \\
(0.0040)\end{array}$ & $\begin{array}{c}-0.0498 * * * \\
(0.0088)\end{array}$ & $\begin{array}{c}-0.0183^{* * *} \\
(0.0057)\end{array}$ & $\begin{array}{c}-0.0674 * * * \\
(0.0152)\end{array}$ & $\begin{array}{c}-0.0219 * * * \\
(0.0083)\end{array}$ & $\begin{array}{c}-0.0672 * * * \\
(0.0227)\end{array}$ & $\begin{array}{l}-0.0025 \\
(0.0069)\end{array}$ & $\begin{array}{c}-0.0255^{* *} \\
(0.0125)\end{array}$ & $\begin{array}{c}0.0005 \\
(0.0087)\end{array}$ & $\begin{array}{c}0.0112 \\
(0.0228)\end{array}$ \\
\hline
\end{tabular}

*** $\mathrm{p}<0.01, * * \mathrm{p}<0.05, * \mathrm{p}<0.1$

Notes: The sample is the March CPS from 1976 to 2012. Micro observatations are used. CPS sample weights are normalized so that each division-graduation year-potexp cell gets the same weight (potexp = years since graduation). Columns 2 and 3 include those age 22-35, not enrolled, with 0 to 13 years potexp. Columns 1 , and 4-6 additionally exclude workers without earnings and those with 0 years potexp. The graduation unemployment rate is the unemployment rate in the division of current residence in the year of college graduation. We also control for survey, major, gender-by-race, and division fixed effects, a cubic time trend, a quadratic in potexp interacted with gender, the earnings return to the major interacted with: the graduation unemployment rate, potential experience and the product of the two. For Panel B, we also include an indicator for whether the person graduated in or after 2004 and the interactions of the post-2004 indicator with the quadratic in potexp, the graduation unemployment rate $\left(\mathrm{U}_{\mathrm{c}}\right), \mathrm{U}_{\mathrm{c}}{ }^{*}$ potexp, and $\mathrm{U}_{\mathrm{c}}{ }^{*}$ potexp ${ }^{2}$. 
Table 5: Effects of 4 ppt rise in $\mathrm{U}_{\mathrm{c}}$ interacted with $\beta^{\text {major }}$

\begin{tabular}{|c|c|c|c|c|c|c|c|c|c|c|c|c|}
\hline & \multicolumn{8}{|c|}{ Employment: } & \multicolumn{4}{|c|}{ Occupation Variables: } \\
\hline & \multicolumn{2}{|c|}{ Log earnings } & \multicolumn{2}{|c|}{$\operatorname{Pr}($ Employed $)$} & \multicolumn{2}{|c|}{$\operatorname{Pr}$ (Full time) } & \multicolumn{2}{|c|}{ Log wages } & \multicolumn{2}{|c|}{ Earnings Return } & \multicolumn{2}{|c|}{$\operatorname{Pr}($ in top 5 occ) } \\
\hline & \multicolumn{2}{|c|}{$(1)$} & \multicolumn{2}{|c|}{ (2) } & \multicolumn{2}{|c|}{ (3) } & \multicolumn{2}{|c|}{$(4)$} & \multicolumn{2}{|c|}{$(5)$} & \multicolumn{2}{|c|}{ (6) } \\
\hline & \multicolumn{12}{|c|}{ Panel A: Coefficients on $\beta^{\text {major }}$ in Earnings Regression } \\
\hline $\begin{array}{c}\text { Main effect } \\
\text { (s.e.) } \\
\beta^{\text {major } * \text { potexp }} \\
\text { (s.e.) }\end{array}$ & \multicolumn{2}{|c|}{$\begin{array}{c}0.1840^{* * *} \\
(0.0066) \\
0.0034^{* * *} \\
(0.0009) \\
\end{array}$} & \multicolumn{2}{|c|}{$\begin{array}{c}0.0040^{*} \\
(0.0023) \\
0.0012^{* * *} \\
(0.0004) \\
\end{array}$} & \multicolumn{2}{|c|}{$\begin{array}{c}0.0506^{* * *} \\
(0.0045) \\
-0.0020^{* * *} \\
(0.0006) \\
\end{array}$} & \multicolumn{2}{|c|}{$\begin{array}{c}0.1536^{* * *} \\
(0.0054) \\
0.0034^{* * *} \\
(0.0007) \\
\end{array}$} & \multicolumn{2}{|c|}{$\begin{array}{c}0.1304^{* * *} \\
(0.0033) \\
0.0003 \\
(0.0004) \\
\end{array}$} & \multicolumn{2}{|c|}{$\begin{array}{c}0.0024 \\
(0.0069) \\
0.0036^{* * *} \\
(0.0009) \\
\end{array}$} \\
\hline & \multicolumn{12}{|c|}{ Panel B: All Graduation Cohorts, 1974-2011 } \\
\hline $\begin{array}{l}\text { Avg. effect for } \\
\text { potexp } 1 \text { to } 10 \\
\text { (s.e.) } \\
\text { At potexp }=\end{array}$ & \multicolumn{2}{|c|}{$\begin{array}{c}0.0200 * * * \\
(0.0060)\end{array}$} & \multicolumn{2}{|c|}{$\begin{array}{c}0.0011 \\
(0.0023)\end{array}$} & \multicolumn{2}{|c|}{$\begin{array}{c}0.0147 * * * \\
(0.0042)\end{array}$} & \multicolumn{2}{|c|}{$\begin{array}{c}0.0102 * * \\
(0.0047)\end{array}$} & \multicolumn{2}{|c|}{$\begin{array}{c}0.0069 * * \\
(0.0031)\end{array}$} & \multicolumn{2}{|c|}{$\begin{array}{c}0.0163 * * * \\
(0.0051)\end{array}$} \\
\hline 1 & \multicolumn{2}{|c|}{$\begin{array}{c}0.0545^{* * *} \\
(0.0107)\end{array}$} & \multicolumn{2}{|c|}{$\begin{array}{l}0.0067 * \\
(0.0040)\end{array}$} & \multicolumn{2}{|c|}{$\begin{array}{c}0.0299 * * * \\
(0.0077)\end{array}$} & \multicolumn{2}{|c|}{$\begin{array}{c}0.0229 * * * \\
(0.0084)\end{array}$} & \multicolumn{2}{|c|}{$\begin{array}{c}0.0111^{* *} \\
(0.0055)\end{array}$} & \multicolumn{2}{|c|}{$\begin{array}{c}0.0061 \\
(0.0086)\end{array}$} \\
\hline 3 & \multicolumn{2}{|c|}{$\begin{array}{c}0.0392 * * * \\
(0.0082)\end{array}$} & $\begin{array}{r}0.00 \\
(0.00\end{array}$ & 42 & $\begin{array}{r}0.023 \\
(0.00\end{array}$ & $\begin{array}{l}31^{* * * *} \\
059)\end{array}$ & $\begin{array}{r}0.01 \\
(0.0\end{array}$ & $\begin{array}{l}3 * * * \\
64)\end{array}$ & $\begin{array}{l}0.00 \\
(0.0\end{array}$ & $\begin{array}{l}2 * * \\
42)\end{array}$ & $\begin{array}{r}0.0 \\
(0.0\end{array}$ & $\begin{array}{l}106 \\
067)\end{array}$ \\
\hline 7 & $\begin{array}{l}0.00 \\
(0.0\end{array}$ & $\begin{array}{l}086 * \\
056)\end{array}$ & $\begin{array}{l}-0.0 \\
(0.00\end{array}$ & $\begin{array}{l}007 \\
024)\end{array}$ & $\begin{array}{r}0.009 \\
(0.00\end{array}$ & $\begin{array}{l}6 * * * \\
037)\end{array}$ & $\begin{array}{r}0.0 \\
(0.0\end{array}$ & & $\begin{array}{l}0.00 \\
(0.0\end{array}$ & 28) & $\begin{array}{r}0.01 \\
(0.0\end{array}$ & $\begin{array}{l}7 * * * \\
050)\end{array}$ \\
\hline 10 & $\begin{array}{r}-0.01 \\
(0.0 \\
\end{array}$ & $\begin{array}{l}144^{* *} \\
074)\end{array}$ & $\begin{array}{l}-0.0 \\
(0.00 \\
\end{array}$ & $\begin{array}{r}045 \\
36) \\
\end{array}$ & $\begin{array}{l}-0.0 \\
(0.00 \\
\end{array}$ & $\begin{array}{l}005 \\
048)\end{array}$ & $\begin{array}{l}-0 . \\
(0.0 \\
\end{array}$ & $\begin{array}{l}026 \\
61) \\
\end{array}$ & $\begin{array}{r}0.0 \\
(0.0 \\
\end{array}$ & 27 & $\begin{array}{r}0.02 \\
(0.0 \\
\end{array}$ & $\begin{array}{l}5 * * * \\
568)\end{array}$ \\
\hline & & & & Panel C: & Pre-2004 G & sraduation & Cohorts ve & us 2004 & and After & & & \\
\hline & Pre & Post & Pre & Post & Pre & Post & Pre & Post & Pre & Post & Pre & Post \\
\hline 1 & $\begin{array}{c}0.0635^{* * *} \\
(0.0139)\end{array}$ & $\begin{array}{c}0.0316^{* * *} \\
(0.0142)\end{array}$ & $\begin{array}{c}0.0138^{* * *} \\
(0.0053)\end{array}$ & $\begin{array}{l}-0.0075 \\
(0.0067)\end{array}$ & $\begin{array}{c}0.0565^{* * *} \\
(0.0105)\end{array}$ & $\begin{array}{c}-0.0201^{* *} \\
(0.0099)\end{array}$ & $\begin{array}{c}0.0233^{* *} \\
(0.0109)\end{array}$ & $\begin{array}{l}0.0200^{*} \\
(0.0116)\end{array}$ & $\begin{array}{c}0.0184^{* * *} \\
(0.0072)\end{array}$ & $\begin{array}{l}-0.0010 \\
(0.0078)\end{array}$ & $\begin{array}{c}0.0017 \\
(0.0114\end{array}$ & $\begin{array}{c}0.0165 \\
(0.0117)\end{array}$ \\
\hline 3 & $\begin{array}{c}0.0461 * * * \\
(0.0107)\end{array}$ & $\begin{array}{c}0.0147 \\
(0.0096)\end{array}$ & $\begin{array}{l}0.0096^{* *} \\
(0.0040)\end{array}$ & $\begin{array}{c}-0.0056 \\
(0.0041)\end{array}$ & $\begin{array}{c}0.0432 * * * \\
(0.0081)\end{array}$ & $\begin{array}{c}-0.0135^{* *} \\
(0.0061)\end{array}$ & $\begin{array}{c}0.0174 * * \\
(0.0084)\end{array}$ & $\begin{array}{c}0.0031 \\
(0.0079)\end{array}$ & $\begin{array}{c}0.0149 * * * \\
(0.0056)\end{array}$ & $\begin{array}{c}-0.0038 \\
(0.0048)\end{array}$ & $\begin{array}{c}0.0072 \\
(0.0088)\end{array}$ & $\begin{array}{c}0.0012 \\
(0.0084)\end{array}$ \\
\hline
\end{tabular}

$* * * \mathrm{p}<0.01, * * \mathrm{p}<0.05, * \mathrm{p}<0.1$

Notes: The sample is the combined data set described in the text. Observations are major-gradyear-division-potexp cells, weighted by the major's share within division-gradyear-potexp group (potexp = years since graduation). Sample for columns 1, 4, 5, and 6 includes nonenrolled workers age 22-35 with potential experience 1 to 13 with a valid annual earnings observation (greater than \$500 in 2006 dollars). The regression samples for employed and full-time exclude enrolled workers but have no restriction on earnings, and also include those with potential experience equal to zero. Uc is the divisional unemployment rate in the year the cohort graduated from college. $\beta$ major is the earnings return to the major, estimated on a sample of workers age 36-59 in our pooled, unweighted data. In Panel A, we report the coefficients on $\beta^{\text {major }}$ and $\beta^{\text {major }}$ potexp in a regression without major fixed effects. For Panel B, we control for survey, major, gender-by-race, and division fixed effects, a cubic time trend, a quadratic in potexp interacted with gender, the earnings return to the major interacted with: the graduating unemployment rate, potential experience and the product of the two. For Panel C, we also include an indicator for whether the person graduated in or after 2004 and the interactions of the post-2004 indicator with the quadratic in potexp, the graduation unemployment rate $\left(U_{c}\right), U_{c}^{*}$ potexp, $U_{c}{ }^{*}$ potexp ${ }^{2}$, the earnings return to the major and with all of the interaction terms involving the earnings return to the major. 
Table 6: Probability of Attaining an Advanced Degree

Sample: ACS College Graduates who Graduated from 1976-2007

\begin{tabular}{l|ccc}
\hline & $(1)$ & $(2)$ & $(3)$ \\
\hline Entry unemployment rate $\left(\mathrm{U}_{\mathrm{c}}\right)$ & $0.0012^{*}$ & $0.0014^{* *}$ & $0.0013^{* *}$ \\
& $(0.0006)$ & $(0.0006)$ & $(0.0006)$ \\
\hline$\beta^{\text {major }}$ & $-0.0068^{* * *}$ & & \\
& $(0.0012)$ & & \\
\hline$\beta^{\text {major }_{*} \mathrm{U}_{\mathrm{c}}}$ & $-0.0027^{* * *}$ & $-0.0020^{* * *}$ & $-0.0010^{*}$ \\
& $(0.0006)$ & $(0.0005)$ & $(0.0005)$ \\
\hline & & & $\mathrm{X}$ \\
Major fixed effects & $\mathrm{X}$ & $\mathrm{X}$ & $\mathrm{X}$ \\
Grad year fixed effects & $\mathrm{X}$ & $\mathrm{X}$ & $\mathrm{X}$ \\
Cluster at grad year-division & & & $\mathrm{X}$ \\
$\beta^{\text {major }}$ interacted with cubic time trend & $1,428,234$ & $1,428,234$ & $1,428,234$ \\
Observations & 0.011 & 0.082 & 0.082 \\
R-squared & & & \\
\hline
\end{tabular}

$* * * \mathrm{p}<0.01, * * \mathrm{p}<0.05, * \mathrm{p}<0.1$

Notes: The sample is college graduates in the ACS 2009-2012 who graduated from 1976 to 2007 with at least 5 years of potential experience. We exclude enrolled people. The dependent variable an indicator for whether the person has an advanced degree. $\beta^{\text {major }}$ is the earnings return to the major, estimated on a sample of workers age 36-59 in our pooled, unweighted data. $U_{c}$ is the divisional unemployment rate in the year of college graduation, measured as deviation from the mean divisional unemployment rate over this period. 
Table 7: Sensitivity of College Major-Specific Unemployment Rates to the Overall Unemployment Rate

\begin{tabular}{l|c|cc|c}
\hline & \multicolumn{4}{|c}{ Dependent Variable: $\mathrm{U}_{\mathrm{c}}^{\text {major }}$} \\
& $1971-2012$ & $1971-2003$ & $1971-2003$ & $2004-2012$ \\
\hline \multirow{3}{*}{ Entry unemployment rate $\left(\mathrm{U}_{\mathrm{c}}\right)$} & $(1)$ & $(2)$ & $(3)$ & $(4)$ \\
& $0.2552^{* * *}$ & $0.2055^{* * *}$ & $0.1997^{* * *}$ & $0.5080^{* * *}$ \\
$\beta^{\text {major }}$ & $(0.0173)$ & $(0.0179)$ & $(0.0175)$ & $(0.0277)$ \\
& $-0.1979^{* * *}$ & $-0.2151^{* * *}$ & $-0.2151^{* * *}$ & $-0.1527^{* * *}$ \\
$\beta^{\text {major }} \mathrm{U}_{\mathrm{c}}$ & $(0.0077)$ & $(0.0088)$ & $(0.0088)$ & $(0.0147)$ \\
& $-0.0257^{* * *}$ & $-0.0344^{* * *}$ & $-0.0344^{* * *}$ & $-0.0126^{* *}$ \\
& $(0.0038)$ & $(0.0039)$ & $(0.0039)$ & $(0.0057)$ \\
Cubic time trend & & & & \\
Observations & $\mathrm{X}$ & & $\mathrm{X}$ & \\
R-squared & 16,983 & 12,852 & 12,852 & 4,131 \\
\hline
\end{tabular}

$* * * \mathrm{p}<0.01, * * \mathrm{p}<0.05, * \mathrm{p}<0.1$

Note: The dependent variable in all columns is the major-specific unemployment rate, created using occupation-industryspecific unemployment rates and a major-to-occupation-industry mapping, all using workers aged 26 to 59 in the ACS and NSCG data sets. These unemployment rates are at the division level. No other controls are included except when we use a cubic time trend. The unemployment rate on the right hand side is the overall divisional unemployment rate, measured as deviation from the mean divisional unemployment rate over this period. 
Appendix Table 1: Data Sources (Combined Earnings Sample)

\begin{tabular}{l|rrr}
\hline Data source & Grad years & Earnings years & Earnings observations \\
\hline NLSY79 & $1979-1989$ & $1980-1993,1995-2001^{*}$ & 10,472 \\
NLSY97 & $2000-2008$ & $2003-2009$ & 3,317 \\
NLS72 & $1976-1978$ & $1977-1986$ & 7,929 \\
B\&B 93/03 & 1993 & $1994,1997,2003$ & $11,120^{* *}$ \\
B\&B 08/09 & 2008 & 2009 & $6,390^{* *}$ \\
NSCG 1993 & $1977-1990$ & 1990,1993 & 58,460 \\
NSCG 2003 & $1990-2000$ & 2003 & 11,533 \\
ACS 09-12 & $1996-2011$ & $2009-2012$ & 387,585 \\
SIPP & $1976-2009$ & $1984-2011$ & 40,666 \\
\hline
\end{tabular}

Notes: An observation here is a worker-year. Valid earnings observations are defined as observations in which the worker is not enrolled in school and has at least $\$ 500$ in annual earnings in 2006 dollars. We restrict to workers aged 22 to 35 with 1 to 13 years of potential experience, defined as years since graduation.

*Excludes even-numbered years from 1995-2001 due to sample design

**Rounded to nearest 10 for confidentiality reasons. 
Appendix Table 2

Unweighted Sample Coverage: Graduation Unemployment Rates and Potential Experience

\begin{tabular}{l|r|r|r|r|r|r}
\hline \multicolumn{7}{c}{ Years since college graduation } \\
$\mathrm{U}_{\mathrm{c}}$ & $1-2$ & $3-4$ & $5-7$ & $8-10$ & $11-13$ & Total \\
\hline$<5 \%$ & 15,982 & 26,645 & 37,307 & 32,140 & 28,771 & 140,845 \\
$5-6 \%$ & 16,714 & 22,676 & 34,714 & 30,068 & 22,751 & 126,923 \\
$6-7 \%$ & 13,387 & 18,438 & 26,279 & 24,967 & 19,213 & 102,284 \\
$7-8 \%$ & 11,944 & 12,674 & 20,457 & 19,207 & 16,201 & 80,483 \\
$8-9 \%$ & 6,331 & 6,555 & 9,611 & 7,733 & 7,507 & 37,737 \\
$>9 \%$ & 8,821 & 9,082 & 12,131 & 11,154 & 7,449 & 48,637 \\
\hline Total & 73,179 & 96,070 & 140,499 & 125,269 & 101,892 & 536,909 \\
\hline
\end{tabular}

Notes: An observation here is a worker-year. This table includes only valid earnings observations, defined as a worker aged 22 to 35 with potential experience 1 to 13 with at least $\$ 500$ in annual earnings in 2006 dollars. $U_{c}$ is the annual census division unemployment rate. Potential experience is years since graduation. 
Appendix Table 3: Log Annual Earnings as a Function of Entry Conditions and Major Characteristics

\begin{tabular}{|c|c|c|c|c|c|c|c|}
\hline & $(1)$ & $(2)$ & (3) & $(4)$ & $(5)$ & (6) & $(7)$ \\
\hline Entry unemployment rate $\left(\mathrm{U}_{\mathrm{c}}\right)$ & $\begin{array}{c}-0.0294 * * * \\
(0.0060) \\
\end{array}$ & $\begin{array}{c}-0.0257 * * * \\
(0.0067) \\
\end{array}$ & $\begin{array}{c}-0.0252 * * * \\
(0.0047) \\
\end{array}$ & $\begin{array}{c}-0.0189 * * * \\
(0.0072) \\
\end{array}$ & $\begin{array}{c}-0.0238 * * * \\
(0.0050)\end{array}$ & $\begin{array}{c}-0.0174 * * * \\
(0.0039) \\
\end{array}$ & $\begin{array}{c}-0.0117 * * \\
(0.0048) \\
\end{array}$ \\
\hline Post*Uc & & & & $\begin{array}{c}-0.0419 * * * \\
(0.0092)\end{array}$ & $\begin{array}{c}-0.0342 * * * \\
(0.0092)\end{array}$ & & $\begin{array}{l}-0.0107 \\
(0.0078)\end{array}$ \\
\hline $\mathrm{U}_{\mathrm{c}}^{*}$ potexp & $\begin{array}{c}0.0115^{* * *} \\
(0.0022)\end{array}$ & $\begin{array}{c}0.0102 * * * \\
(0.0023)\end{array}$ & $\begin{array}{c}0.0103 * * * \\
(0.0015)\end{array}$ & $\begin{array}{c}0.0093 * * * \\
(0.0025)\end{array}$ & $\begin{array}{c}0.0103 * * * \\
(0.0017)\end{array}$ & $\begin{array}{c}0.0052 * * * \\
(0.0014)\end{array}$ & $\begin{array}{c}0.0038 * * \\
(0.0016)\end{array}$ \\
\hline Post*Uc*potexp & & & & $\begin{array}{c}0.0290 * * * \\
(0.0060)\end{array}$ & $\begin{array}{c}0.0300 * * * \\
(0.0061)\end{array}$ & & $\begin{array}{c}0.0050 \\
(0.0045)\end{array}$ \\
\hline $\mathrm{U}_{\mathrm{c}}{ }^{*}$ potexp ${ }^{2}$ & $\begin{array}{c}-0.0009 * * * \\
(0.0002)\end{array}$ & $\begin{array}{c}-0.0007^{* * *} \\
(0.0002)\end{array}$ & $\begin{array}{c}-0.0008^{* * *} \\
(0.0001)\end{array}$ & $\begin{array}{c}-0.0007^{* * *} \\
(0.0002)\end{array}$ & $\begin{array}{c}-0.0008 * * * \\
(0.0001)\end{array}$ & $\begin{array}{c}-0.0004^{* * *} \\
(0.0001)\end{array}$ & $\begin{array}{c}-0.0003^{* *} \\
(0.0001)\end{array}$ \\
\hline Post $^{*} \mathrm{U}_{\mathrm{c}}{ }^{*}$ potexp $^{2}$ & & & & $\begin{array}{c}-0.0047^{* * *} \\
(0.0010)\end{array}$ & $\begin{array}{c}-0.0052 * * * \\
(0.0010)\end{array}$ & & $\begin{array}{l}-0.0021 \\
(0.0014)\end{array}$ \\
\hline$\beta^{\text {major }}$ & & $\begin{array}{c}0.1840 * * * \\
(0.0066)\end{array}$ & & & & & \\
\hline Post* $\beta^{\text {major }}$ & & & & $\begin{array}{c}0.0068 \\
(0.0147)\end{array}$ & $\begin{array}{c}0.0063 \\
(0.0113)\end{array}$ & & \\
\hline$\beta^{\text {major }} *$ potexp & $\begin{array}{c}0.0030^{* * *} \\
(0.0009)\end{array}$ & $\begin{array}{c}0.0034^{* * *} \\
(0.0009)\end{array}$ & $\begin{array}{c}0.0026 * * * \\
(0.0007)\end{array}$ & $\begin{array}{c}0.0031^{* * *} \\
(0.0010)\end{array}$ & $\begin{array}{c}0.0027^{* * *} \\
(0.0008)\end{array}$ & & \\
\hline Post $* \beta^{\text {major }} *$ potexp & & & & $\begin{array}{l}-0.0040 \\
(0.0030)\end{array}$ & $\begin{array}{l}-0.0036 \\
(0.0026)\end{array}$ & & \\
\hline 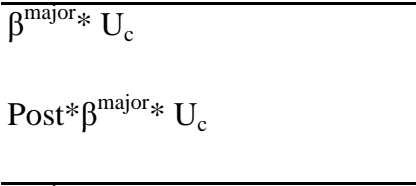 & $\begin{array}{c}0.0139 * * * \\
(0.0036)\end{array}$ & $\begin{array}{c}0.0091^{* *} \\
(0.0038)\end{array}$ & $\begin{array}{c}0.0136 * * * \\
(0.0027)\end{array}$ & $\begin{array}{c}0.0165 * * * \\
(0.0045) \\
-0.0082 \\
(0.0060) \\
\end{array}$ & $\begin{array}{c}0.0159 * * * \\
(0.0035) \\
-0.0080 \\
(0.0050) \\
\end{array}$ & & \\
\hline $\begin{array}{l}\beta^{\text {major }} * U_{c} * \text { potexp } \\
\text { Post } * \beta^{\text {major }} * U_{c} * \text { potexp }\end{array}$ & $\begin{array}{c}-0.0019 * * * \\
(0.0005)\end{array}$ & $\begin{array}{c}-0.0013 * * * \\
(0.0005)\end{array}$ & $\begin{array}{c}-0.0019 * * * \\
(0.0004)\end{array}$ & $\begin{array}{c}-0.0022 * * * \\
(0.0005) \\
-0.0001 \\
(0.0019) \\
\end{array}$ & $\begin{array}{c}-0.0022 * * * \\
(0.0005) \\
0.0001 \\
(0.0017) \\
\end{array}$ & & \\
\hline Major fixed effects & $\mathrm{X}$ & & $\mathrm{X}$ & $\mathrm{X}$ & $\mathrm{X}$ & & \\
\hline Grad year fixed effects & & $\mathrm{X}$ & $\mathrm{X}$ & & $\mathrm{X}$ & & \\
\hline Cluster at grad year-division & $\mathrm{X}$ & $\mathrm{X}$ & & $\mathrm{X}$ & & $\mathrm{X}$ & $\mathrm{X}$ \\
\hline Observations & 56,635 & 56,635 & 56,635 & 56,635 & 56,635 & 209,007 & 209,007 \\
\hline R-squared & 0.328 & 0.312 & 0.335 & 0.331 & 0.335 & 0.164 & 0.165 \\
\hline
\end{tabular}

$* * * \mathrm{p}<0.01, * * \mathrm{p}<0.05, * \mathrm{p}<0.1$

Notes: Columns 1-5 report results from our combined sample. Observations in these regressions are major-gradyear-division-potexp cells. We weight by the major's share of observations in the cohort-potexp group. $U_{c}$ is the divisional unemployment rate in the year the cohort graduated from college. Potexp is years since college graduation. $\beta^{\text {major }}$ is the earnings return to the major, estimated on a sample of workers age 36-59 in our pooled, unweighted data.Survey dummies, year dummies, a quadratic in potential experience, gender, race, and region controls are also included. The sample is non-enrolled workers from age 22 to 35 , with potential experience 1 to 13, with at least \$500 in annual earnings in 2006 dollars. "Post" is defined as graduation years 2004 and later. Columns 6-7 are based on using individual observations from the March CPS, which does not contain major information. CPS survey weights are adjusted to give equal weight to each graduation year-division-potential experience cell equally. 


\section{Data Appendix}

We begin by describing the data sets used in this paper, with the details of variable creation from each data set. Online appendix table 1 summarizes variable definitions by data set. We then describe the creation of characteristics of college majors and occupational attainment variables.

Some variables are created in the same way in all of the data sets. In all data sets, information on race, gender, and age are straightforward to obtain. We code race/ethnicity in three categories: Hispanic, black non-Hispanic, and other non-Hispanic. ${ }^{1}$ Potential experience is defined as year minus bachelor's degree graduation year. All earnings and wage measures are adjusted to 2006 dollars using the Consumer Price Index (CPI). We restrict to earnings greater than $\$ 500$ in our main sample and top code annual earnings at $\$ 400,000$. We exclude enrolled workers and those in the year of college graduation from the earnings sample. CPI-adjusted wages must be greater than 0 and are top- and bottom-coded to be between $\$ 5$ and $\$ 250$ per hour. Analysis of wages and the occupation measures is restricted to those with a valid earnings observation. The sample used to study employment and fulltime employment is restricted to the non-enrolled but includes observations from the year of graduation and includes people with 0 earnings.

Our preferred measure of labor market conditions at graduation is the unemployment rate for the census division level of graduation. The U.S. Census Bureau defines nine divisions: New England, Middle Atlantic, East North Central, West North Central, East South Central, West South Central, South Atlantic, Mountain, and Pacific. We obtain the annual unemployment rate for each census division from the Bureau of Labor Statistics Local Area Unemployment Statistics. We restrict all of our analysis to workers who graduated college between ages 20 and 24, inclusive. This eliminates about $20 \%$ of the available observations in data sets other than the ACS, mostly from late graduates. We cannot impose this restriction on the ACS because graduation year is not available. We also restrict to workers age 22 to 35 with 13 or fewer years of potential experience.

\footnotetext{
${ }^{1}$ Some data sets, including the ACS, have more detailed information on race/ethnicity, but others have only these three options, which is why we use them. Some data sets do not have a "mixed-race" option, so we cannot consistently code mixed-race respondents. We code those who indicate that they are mixed-race as "other non-Hispanic" when mixed race is an option.
} 


\subsection{Data sets}

\section{The National Longitudinal Surveys of Youth}

The National Longitudinal Survey of Youth 1979 (NLSY79) and 1997 (NLSY97) are nationaly representative surveys administered by the Bureau of Labor Statistics. The NLSY79 follows 12,686 youths who were aged 14 to 22 in 1979. Respondents were surveyed each year from 1979 to 1994 and biennially thereafter; because of our restrictions on age and potential experience, we use data through 2000. College graduates in this survey graduated between 1979 and the late 1980s. We drop the military subsample of the NLSY79 and use the remaining observations. The NLSY97 follows almost 9,000 respondents who were aged 12 to 16 in 1996 and have been surveyed annually from 1997-2010. These cohorts graduated from college between 2000 and 2009. In our regressions, we include separate survey fixed effects for the NLSY79 and for the NLSY97.

In both surveys, annual earnings are taken from a direct question about wage and salary earnings in the prior calendar year. ${ }^{2}$ The wage measure is the hourly rate of pay in the current or most recent job. Employment and enrollment are based on questions about status at the time of the survey date. Full-time employment is defined as usually working at least 35 hours per week at the current job and 0 for those working part time or not working. Highest grade completed is taken from a direct question each year about highest degree completed. We use occupation in the current or most recent job, which is available at the 1970 3-digit census categorization over the time period we use. To have consistent coding across data sets, we convert to 1990 3-digit codes using the mapping made available by Ruggles et al. (2010).

Because earnings are defined for the year prior to the survey year, we use information from the previous survey (if there is one available) to make restrictions on the earnings sample. However, we still use the current survey weight. For example, from the 1990 survey we obtain earnings in the previous calendar and the survey weight. We restrict to observations who report not being enrolled in the 1989 survey. (We also use employment and hours from the 1989 survey when those are relevant for sample restrictions, for example when defining $\beta^{\text {major }}$.) When there is no previous survey, we use the current survey. In earnings regressions we lag potential experience and calendar time variables. For wages and occupational attainment variables, we restrict the sample to those with non-missing earnings.

\footnotetext{
${ }^{2}$ For example, the 1990 survey asks for earnings in 1989, and we code these as 1989 annual earnings.
} 
For the NLSY's, this means those with non-missing earnings from the next survey, which refers to earnings measured over the same time period.

Year of college graduation is straightforward to create since both surveys contain questions about educational attainment each year. In the NLSY79, we use the response to the "year of degree" question in the first year after graduation, and then fill in missing values by going forward. In the NLSY97, we use the BLS-created variable for date of bachelor's degree. We use the restricted-access geocodes to gain information on state (and census division) of college degree and current location. If the graduation year is a survey year, we define state of graduation as the state of residence at the time of the survey. Respondents who graduated before 1979 are excluded from our analysis. Less than 10 respondents fit this category.

The NLSY surveys each have their own college major categories; the NLSY79 has hundreds of categories, while the NLSY97 has only about 50. For each survey separately, we construct a crosswalk from the NLSY major categories to the 51 Department of Education categories based on the names of the majors.

\section{The National Survey of College Graduates}

The National Survey of College Graduates 1993 (NSCG93) and 2003 (NSCG03) are crosssectional data sets made up of samples of 148,905 and 100,402 workers, respectively, administered by the National Science Foundation. The sample frame is those who reported having a college degree in the previous decennial census (1990 and 2000, respectively). Given our age restrictions, workers in the NSCG93 sample graduated from college between 1976 and 1990, while the NSCG03 sample graduated between 1986 and 2000.

We obtain the NSCG93 data from the Inter-University Consortium for Political and Social Research (ICPSR), which links respondents to the 1990 decennial census. This allows up to two earnings observations per worker for the NSCG93: 1990 and 1993. We obtain the public-use NSCG03 data from the National Science Foundation website, which does not allow us to link the data to the 2000 census, leaving labor market data measured only in 2003. In both NSCG data sets, we drop observations with imputed earnings. ${ }^{3}$

In both NSCG samples, annual earnings and wages are the same measure: annual salary in the current job. Information on hours worked or hourly pay is not available, so we cannot

\footnotetext{
${ }^{3}$ The imputation flags for the 2003 survey were obtained from the NSF upon request and added to the public-use data. The imputation flags for the 1993 survey are included with the ICPSR data.
} 
construct a separate wage measure. Employment and full-time employment (a direct question on full-time or part-time status) are measured at the survey date. ${ }^{4}$ Enrollment at survey date is available in the NSCG93 but not in the NSCG03. Though we typically exclude enrolled workers from the analyses of labor market outcomes, we must include everyone from the NSCG03 (who meets the other criteria). We therefore treat the NSCG93 and the NSCG03 as separate surveys when coding survey fixed effects. Highest degree completed is taken from a direct question. We convert degree completed to highest grade completed by treating a master's degree as 18 years, a professional degree as 19 years, and a doctoral degree as 20 years. Occupation is reported for the principal job during the reference week. The NSF uses its own occupation codes for the NSCG surveys, which we map into 1990 census 3-digit codes using our own mapping. ${ }^{5}$

Year of college graduation is taken from a direct question, as is division of college graduation in the NSCG93. In the NSCG03, we do not have division of graduation, so instead we use division of current residence. We do not have state-level information. College major is also taken from a direct question, and is based on the NSF's own categories, of which there are about 200. We map these into the Department of Education categories using a mapping based on the names of the majors.

\section{The Baccalaureate and Beyond}

The Baccalaureate and Beyond 1993 (BB93) and 2008 (BB08) are longitudinal surveys administered by the Department of Education National Center for Education Statistics. The BB93 consists of about 11,000 students who graduated from college in 1993. Individuals were surveyed in 1994, 1997, and 2003. The BB08 is composed of about 19,000 college graduates from 2008, who were surveyed in 2009. Because each BB survey covers only one year of graduates, neither survey on its own provides much variation in economic conditions at the time of graduation. Instead these surveys provide cross-sectional variation in college major and division of graduation, and help identify effects of control variables.

In the BB93, annual earnings and wages are the same measure as in the NSCG: annual salary in the current job (or job in the reference month, depending on the survey wave). In

\footnotetext{
${ }^{4}$ The questionnaire defines full-time as working 35 or more hours per week.

${ }^{5}$ The NSF occupation categories tend to be more detailed for science- and engineering-related fields and less detailed for other fields.
} 
the BB08, we use actual earned income in 2009, annualized to account for the date of the survey, for both annual earnings and wages. This only counts earnings in the primary job. Employment, enrollment, and full-time status refer to either the time of the survey or the reference month, depending on the survey wave. Full-time status is a direct question asking full-time or part-time status in the primary job. Highest degree completed and occupation in the primary job at the time of the survey (or in the reference month) are taken from direct questions. The BB has only about 40 occupation categories, which we map into 1990 occupation codes using names of occupations. We treat the three waves BB93 as one survey and the BB08 as another when defining our survey fixed effects.

Year of college graduation is straightforward since in each survey all respondents graduated in the same year. For location of graduation, we utilize a direct question about the state of the respondent's undergraduate institution. Majors are given in about 100 categories in the BB93, which we crosswalk to the Department of Education categories using our own mapping. The BB03 gives majors in CIP codes, which are very similar to the Department of Education codes, so this crosswalk is simple.

\section{The National Longitudinal Study}

The National Longitudinal Study (NLS72) is a panel survey administered by the Department of Education. The sample is about 16,000 high school seniors in 1972, with the bulk of eventual college graduates graduating in 1976. We exploit two waves of the survey with post-graduation information (1979 and 1986); most sample members provided information about 1977 and 1978 in the 1979 wave, while in 1986 a smaller subset of the sample (roughly 40\%) was asked for job and pay information about the years between 1979 and 1986, giving us multiple years of observation. We obtain year of college graduation using the 1976, 1979, and 1986 follow-up waves and questions regarding intervening years. If no other information is available, we assign graduation year as the first year in which a respondent says he or she has at least four years of college. Because these workers are in a single high school graduation cohort, the NLS72 provides little variation in economic conditions at the time of graduation. Thus the same caveats apply here as those described with the BB data sets.

The NLS72 gives us the starting and ending/current wage in the most recent job. Our wage measure is the average of the two. We multiply wages by hours worked in the past year in the most recent job (a direct question) to get the annual earnings measure. Employment 
and occupation are at the time of the survey. Occupation is given in 1970 3-digit census codes, which we map to 1990 codes using the mapping from Ruggles et al. (2010). Highest grade completed is based on a direct question about years of school completed. We do not use enrollment information beyond 1976. Thus we must include all observations meeting the other criteria in our analyses that typically exclude the enrolled. The waves of the NLS72 are treated as one survey from the perspective of our survey fixed effects.

Location of college graduation is determined by using the zip code in the year of presumed graduation, which we map to the state level. College major information is derived from data on the respondents' college transcripts. This has about 50 categories, which we map to the Department of Education codes using our own mapping.

\section{The Survey of Income and Program Participation}

The Survey of Income and Program Participation (SIPP) is a series of two-, three-, and four-year panels covering the period from 1984 to 2011, administered by the U.S. Census Bureau. $^{6}$ Each worker is surveyed every four months during his or her panel's stay in the sample and provides monthly data on employment, earnings, hourly wages, enrollment, and other key variables. Combining all the panels of SIPP together, we have about 60,000 personyear observations. Respondents in our restricted age range graduated between 1971 and 2008, and we have earnings observations from 1984 to $2011 .^{7}$ From 1984 to 1993 (excluding 1985), field of bachelor's degree can only be measured with certainty for those with exactly a bachelor's degree, because the survey only asks for field of highest degree. In those waves, we therefore only use respondents with exactly a bachelor's degree, whereas all college graduates are included from 1996 forward. We treat the two time periods (survey panels 1984-1993, and survey panels 1996-2008 ${ }^{8}$ ) as two separate surveys from the perspective of our survey fixed effects.

We define annual earnings as the average monthly earnings for non-enrolled months times

\footnotetext{
${ }^{6}$ The education module which asks for degree and major information is not included in the 1985 panel, and therefore we do not use it. The 1984 panel does not have enrollment information, so for this panel we treat all workers as not enrolled.

${ }^{7}$ Because data from the last panel was only available through part of 2012 at the time of this analysis, we do not use 2012 earnings information.

${ }^{8}$ The last panel began in 2008 and has data through 2011 (as of the time of our analysis); we refer to this as the 2008 panel.
} 
twelve. Wages are earnings divided by the sum of hours worked across all months where the respondent was not enrolled. ${ }^{9}$ Respondents report earnings and hours separately for up to two jobs per month, and we include earnings from both jobs in our measures of earnings and wages. Employment is the fraction of non-enrolled months the worker worked at least one week, and full-time is defined as the fraction of non-enrolled months the worker worked at least 35 hours per week. Occupation is the primary occupation in each month.

The education module in the second wave contains direct questions on year and field of degree. We do not have location of degree and instead use the state of residence in the earliest wave of the panel. Panels 1984-1993 contains one set of 20 major classifications, while panels 1996-2008 contain a different set of 18 major classifications. ${ }^{10}$ This is another reason why we treat the early and later SIPP panels as two separate surveys when defining survey fixed effects. These major categories are listed in online appendix tables $2 \mathrm{a}$ and $2 \mathrm{~b}$, respectively. For some variables, we must generate a crosswalk between these classifications and the 51 Department of Education categories. We do so based on the names of the majors and report the crosswalks in online appendix tables $8 \mathrm{a}$ and 8b. We cannot link medicine/dentistry and vocational studies from the early panels and liberal arts/humanities from the later panels to the 51 Department of Education categories. These majors are therefore dropped from analyses where the use of the crosswalks is necessary. When we include major fixed effects in our regressions, we treat the SIPP majors as distinct from the Department of Education majors, giving us a total of 89 major categories.

Highest grade completed can be defined from direct questions about highest degree completed in the second wave of each panel. Workers could still have obtained further schooling by the later waves of a given panel, but we cannot observe this. Enrolled is defined as the fraction of months in a given year where the worker was enrolled.

\section{The American Community Survey}

The American Community Survey (ACS), administered annually since 2001 by the U.S. Census Bureau, consists of large repeat cross-sections meant to substitute for the decennial census. In 2009, the survey introduced a question on college major. We therefore take

\footnotetext{
${ }^{9}$ An hourly rate of pay measure is available, but only for the minority of workers who are paid hourly.

${ }^{10}$ Because the early panels have field of highest degree rather than field of bachelor's degree, the major categories include things generally related to graduate degrees, such as law and medicine. The categories in the later panels, which ask for field of bachelor's degree, are more typical of a bachelor's degree.
} 
advantage of the four survey waves: 2009, 2010, 2011 and 2012. which each cover roughly 2 million households. Our age restrictions leave us with respondents who graduated from college between 1996 and 2011. We categorize all three ACS waves as one survey for the purposes of our survey fixed effects.

The earnings measure is total wage and salary income in the past 12 months. Unfortunately, we do not know when the respondent was interviewed, and thus we do not know if the earnings refers mostly to the prior year, to the current year, or equally to both. We therefore follow the ACS's own reporting practices and assign the earnings as being measured in the survey year, rather than the prior calendar year. To construct wages, we divide annual earnings by the product of weeks worked in the prior 12 months and usual hours per week. Employment and enrollment are defined at the survey date. We define a worker as being employed full-time if at the survey date he or she reports usually working at least 35 hours per week. Highest grade completed is based on a question about highest degree completed. Occupation is available at the 1990 census 3-digit level using the variable created by Ruggles et al (2010), and reflects the most recent job.

The ACS unfortunately does not contain time or location of college degree. We instead impute the year of graduation as the year a respondent was likely 22 (the modal age in the other data sets) in May. For workers born in the first two quarters of the year, the year of graduation is birth year plus 22. For workers born in the second half of the year, graduation year is birth year plus 23. ${ }^{11}$ We use current state and division of residence as the graduating state and division. The ACS has its own categories for college major, which we map to the Department of Education categories based on major names.

We use a subset of our ACS sample to analyze educational attainment, as described in section 6. For this analysis, we expand the non-enrolled sample to include older respondents whose implied graduation date falls between 1976 and 2007 and was at least 5 years before the survey date.

The Current Population Survey March Supplement The Current Population Survey (CPS) March Supplement, is an annual supplement to the monthly Bureau of Labor Statistics CPS used to generate data on the employment situation. The supplement contains information about labor market outcomes at the survey date and over the previous

\footnotetext{
${ }^{11}$ Results are robust to choice of the quarter cut-off.
} 
calendar year. Construction of thevariables used in the analysis of effects of entry conditions for college graduates as a whole (Table 4) are fairly standard, so we will not go into details.

We also use the March CPS from 1971 to 2012 to generate supplemental information on employment and unemployment across occupations and industries. (Table 6 and Figure 2). For each 3-digit 1990 census occupation and one-digit industry (12 categories based on the 1990 census codes: agriculture, mining and construction, durable manufacturing, non-durable manufacturing, transportation and utilities, wholesale and retail trade, finance and real estate, business services, personal services, entertainment, professional services, and public administration) pairing we create measures of annual employment and unemployment. We restrict the sample to employed college graduates aged 25 to 59. An occupation-industryspecific unemployment rate is defined as the number of unemployed workers who were most recently employed in that occupation-industry, divided by those unemployed workers plus employment in the occupation-industry. We then aggregate these unemployment rates to the major level using a major to occupation-industry mapping, which we describe in the

next section. We use a similar approach to generate a major-specific employment growth measure (the first difference in log employment).

\subsection{Major Characteristics}

In all data sets but the SIPP, it is straightforward to map majors into 51 categories used by the Department of Education. We regress log annual earnings on controls (gender, race, region, potential experience, and year dummies) and major fixed effects, separately for the pooled data and the SIPP, with psychology as the excluded category in each regression. The major fixed effects are the major earnings measure. This regression is performed on those aged 36 to 59, which excludes the main estimation sample to avoid any simultaneity concerns. We standardize the major fixed effects by subtracting each sample mean (the combined or the SIPP) and dividing by the combined sample standard deviation (so the units are comparable in the SIPP).

The occupational concentration of the major is also obtained for the 51 major categories and then mapped into the SIPP. For this variable, we pool the non-SIPP data and compute the fraction of people in each major that go into each 1990 census 3-digit occupation. Our preferred measure is the share of workers from each major that go into the five most common 
occupations, but results are similar for the top three and top seven as well. This measure is obtained using only those age 25 to 36 .

For the major-specific demand measures described in the previous section (using the March CPS), we require a major to have an occupation-industry mapping. We obtain this by pooling the ACS and NSCG03 (the NSCG93 does not have information on industry). Using employed college graduates aged 25 to 59, we find the share of employment from each

major in each occupation-industry cell, using 3-digit occupation codes and 1-digit industry codes, both from the 1990 classification. We then apply this mapping to the occupationindustry measures from the March CPS to get major-level measures. This mapping is from the Department of Education major categories to occupation-industry cells. Once we have obtained the major-specific unemployment rate and employment growth, we map it into SIPP categories using our crosswalk.

\subsection{Occupation variables}

We exploit the large samples in the ACS to create two occupation variables. The first is the estimated earnings return to the 3-digit 1990 census occupation averaged over the 4 survey years (2009-2012). For a sample of non-enrolled, full-time employed workers aged 25-59, earning at least $\$ 500$ in the past 12 months, we regress log annual earnings on worker characteristics (the standard controls included in all the previous regressions plus a cubic in potential experience and year effects) and occupation fixed effects. We use these occupation fixed effects as our measure of occupation quality, merging them at the 3-digit census code level for the occupations reported in the pooled data. We could have instead estimated occupation return from our pooled data sets, but we prefer the precision and consistency of the large ACS samples. We have also estimated a wage return to occupation (estimating the regression described above but on log wages - earnings divided by the product of weeks and usual hours) and obtained extremely similar results. This is not surprising given a 0.98 correlation between the two measures. For the SIPP, this measure is the average earnings return across all months in the year with a valid occupation observation.

The second occupation, measure which we use as an indicator of match quality in the current job, is an indicator for whether the current occupation (reported in the pooled data) is among the top 5 occupations for a given major, using 1990 census 3-digit occupation codes. 
We classify the top 5 occupations for each major using the same sample and restrictions as the occupation earnings return. For the SIPP we define these internally then take the average of the top 5 variable across all months in a year.

\section{References}

[1] Ruggles, Steven, J. Trend Alexander, Katie Grenadek, Ronald Goeken, Matthew B. Schroeder, and Matthew Sobek (2010). Integrated Public Use Microdata Series: Version 5.0 [Machine-readable database]. Minneapolis, MN: Minnesota Population Center. 


\begin{tabular}{|c|c|c|c|c|c|c|c|c|c|c|c|}
\hline Variable & NLSY79 & NLSY97 & NLS72 & $\begin{array}{l}\text { Online Appendix Ta } \\
\text { B\&B 93/03 }\end{array}$ & $\begin{array}{l}\text { able 1: Details of Variables of } \\
\text { B\&B 08/09 }\end{array}$ & $\begin{array}{r}\text { If Interest by Data Set } \\
\text { NSCG933 }\end{array}$ & NSCG03 & ACS 09-11 & SIPP 84-93 & SIPP 96-08 & March CPS \\
\hline Annual earnings & \begin{tabular}{|l} 
Earnings in prior calendar \\
year
\end{tabular} & \begin{tabular}{|l} 
Earnings in prior calendar \\
year
\end{tabular} & \begin{tabular}{|l} 
Wage in primary job times \\
annual hours in that job
\end{tabular} & $\begin{array}{l}\text { Annual salary in current job } \\
\text { or job in reference month } \\
\text { (depending on wave) }\end{array}$ & $\begin{array}{l}\text { Earnings in 2009, } \\
\text { annualized to adjust for the } \\
\text { timing of the interview }\end{array}$ & Annual salary in current job & Annual salary in current $j$ & $\begin{array}{l}\text { Total wage and salary } \\
\text { earnings over past } 12 \\
\text { months }\end{array}$ & $\begin{array}{l}\text { Sum of monthly earnings } \\
\text { over the year }\end{array}$ & $\begin{array}{l}\text { Sum of monthly earnings } \\
\text { over the year }\end{array}$ & $\begin{array}{l}\text { Earnings in prior calendar } \\
\text { year }\end{array}$ \\
\hline Rate of pay (wages) & $\begin{array}{l}\text { Hourly rate of pay in } \\
\text { current/most recent job }\end{array}$ & \begin{tabular}{|l} 
Hourly rate of pay in \\
current/most recent job
\end{tabular} & $\begin{array}{l}\text { Average of starting and } \\
\text { ending/current wages in } \\
\text { primary job }\end{array}$ & \begin{tabular}{|l} 
Annual salary in current job \\
or job in reference month \\
(depending on wave)
\end{tabular} & $\begin{array}{l}\text { Earnings in current year, } \\
\text { annualized }\end{array}$ & Annual salary in current job & Annual salary in current job & $\begin{array}{l}\text { Earnings divided by the } \\
\text { product of weeks worked in } \\
\text { past } 12 \text { months and usual } \\
\text { hours worked }\end{array}$ & \begin{tabular}{|l} 
Annualized earnings \\
divided by total hours over \\
the year
\end{tabular} & \begin{tabular}{|l}
$\begin{array}{l}\text { Annualized earnings } \\
\text { divided by total hours over } \\
\text { the year }\end{array}$ \\
\end{tabular} & \begin{tabular}{|l} 
Earnings divided by the \\
product of weeks worked in \\
past 2 months and usual \\
hours worked
\end{tabular} \\
\hline Employment & Employed at date of survey & Employed at date of survey & Employed at date of survey & $\begin{array}{l}\text { Employed at date of survey } \\
\text { or in reference month }\end{array}$ & $\begin{array}{l}\text { Employed in reference } \\
\text { month }\end{array}$ & Employed at date of survey & Employed at date of survey & Employed at date of survey & $\begin{array}{l}\text { Fraction of the year } \\
\text { employed and not enrolled } \\
\text { (months employed divided } \\
\text { by 12) }\end{array}$ & \begin{tabular}{|l} 
Fraction of the year \\
employed and not enrolled \\
(months employed divided \\
by 12)
\end{tabular} & $\begin{array}{l}\text { Employed in reference } \\
\text { week of survey }\end{array}$ \\
\hline Full-time employment & $\begin{array}{l}\text { Usually work } 35 \text { or more } \\
\text { hours per week }\end{array}$ & $\begin{array}{l}\text { Usually work } 35 \text { or more } \\
\text { hours per week }\end{array}$ & $\begin{array}{l}\text { Annual hours greater than } \\
1,750(35 * 50)\end{array}$ & $\begin{array}{l}\text { Question asks full-time or } \\
\text { part-itie, at time of survey } \\
\text { or reference month }\end{array}$ & $\begin{array}{l}\text { At least } 35 \text { hours per week } \\
\text { in } 2009\end{array}$ & $\begin{array}{l}\text { Question asks full-time or } \\
\text { part-time; questionnaire } \\
\text { defines full-time as } 35 \text { or } \\
\text { more hours per week }\end{array}$ & \begin{tabular}{|l} 
Question asks full-time or \\
part-time; questionnaire \\
defines full-time as 35 or \\
more hours per week
\end{tabular} & $\begin{array}{l}\text { Usually work } 35 \text { or more } \\
\text { hours per week }\end{array}$ & \begin{tabular}{|l} 
Fraction of the year \\
working 35 or more hours \\
per week and not enrolled
\end{tabular} & \begin{tabular}{|l} 
Fraction of the year \\
working 35 or more hours \\
per week and not enrolled
\end{tabular} & \begin{tabular}{|l} 
At least 35 hours worked in \\
reference week of survey
\end{tabular} \\
\hline Occupation & Current/most recent job & Current/most recent job & $\begin{array}{l}\text { Primary job at time of } \\
\text { survey (not necessarily } \\
\text { current) }\end{array}$ & $\begin{array}{l}\text { Job at time of survey or in } \\
\text { reference month }\end{array}$ & $\begin{array}{l}\text { Primary job at time of } \\
\text { survey }\end{array}$ & \begin{tabular}{|l} 
Principal job in survey \\
reference week
\end{tabular} & \begin{tabular}{|l} 
Principal job in survey \\
reference week
\end{tabular} & Job at time of survey & $\begin{array}{l}\text { Primary occupation given } \\
\text { each month; for occupation } \\
\text { measures, we use average } \\
\text { of the } 12\end{array}$ & $\begin{array}{l}\text { Primary occupation given } \\
\text { each month; for occupation } \\
\text { measures, we use average } \\
\text { of the } 12\end{array}$ & Job at time of survey \\
\hline Enrollment & Enrolled at time of survey & Enrolled at time of survey & $\begin{array}{l}\text { No enrollment information } \\
\text { after } 1976\end{array}$ & \begin{tabular}{|l|l|} 
Enrolled at time of survey \\
or in reference month
\end{tabular} & Enrolled at time of survey & No enrollment information & $\begin{array}{l}\text { Enrolled during reference } \\
\text { week }\end{array}$ & Enrolled at time of survey & $\begin{array}{l}\text { Fraction of the year } \\
\text { enrolled (no enrollment } \\
\text { information in } 1984 \text { panel) }\end{array}$ & \begin{tabular}{|l} 
Fraction of the year \\
enrolled
\end{tabular} & Enrolled at time of survey \\
\hline Highest grade completed & Highest degree completed & Highest degree completed & $\begin{array}{l}\text { Years of schooling } \\
\text { completed }\end{array}$ & Highest degree completed & Highest degree completed & Highest degree completed & Highest degree completed & $\begin{array}{l}\text { Years of schooling } \\
\text { completed }\end{array}$ & Highest degree completed & Highest degree completed & $\begin{array}{l}\text { Highest grade or degree } \\
\text { completed }\end{array}$ \\
\hline Year of graduation & $\begin{array}{l}\text { Use questions on highest } \\
\text { degree completed each year }\end{array}$ & $\begin{array}{l}\text { Created variable for year of } \\
\text { bachelor's degree }\end{array}$ & $\begin{array}{l}\text { Use questions on highest } \\
\text { grade completed each year }\end{array}$ & All 1993 & All 2008 & $\begin{array}{l}\text { Direct question about first } \\
\text { bachelor's degree }\end{array}$ & $\begin{array}{l}\text { Direct question about first } \\
\text { bachelor's degree }\end{array}$ & $\begin{array}{l}\text { Imputed from year and } \\
\text { quarter of birth }\end{array}$ & Direct question & Direct question & Imputed from year of birth \\
\hline Location of graduation & $\begin{array}{l}\text { State of residence in year of } \\
\text { graduation }\end{array}$ & $\begin{array}{l}\text { ftate of residence in year of } \\
\text { graduation }\end{array}$ & $\begin{array}{l}\text { Zip code in year of } \\
\text { graduation }\end{array}$ & $\begin{array}{l}\text { Direct question about state } \\
\text { of undergraduate institution }\end{array}$ & $\begin{array}{l}\text { Direct question about state } \\
\text { of undergraduate institution }\end{array}$ & \begin{tabular}{|l} 
Direct question about \\
Census division of first \\
bachelor's degree
\end{tabular} & $\begin{array}{l}\text { No location of graduation } \\
\text { information; we use } \\
\text { location of current } \\
\text { residence }\end{array}$ & $\begin{array}{l}\text { No location of graduation } \\
\text { information; we use } \\
\text { location of current } \\
\text { residence }\end{array}$ & $\begin{array}{l}\text { No location of graduation } \\
\text { information; we use } \\
\text { location of current } \\
\text { residence }\end{array}$ & $\begin{array}{l}\text { No location of graduation } \\
\text { information; we use } \\
\text { location of current } \\
\text { residence }\end{array}$ & $\begin{array}{l}\text { No location of graduation } \\
\text { information; we use } \\
\text { location of current } \\
\text { residence }\end{array}$ \\
\hline College major & $\begin{array}{l}\text { Direct questions; hundreds } \\
\text { of categories }\end{array}$ & $\begin{array}{l}\text { Direct questions; roughly } \\
50 \text { categories }\end{array}$ & \begin{tabular}{|l} 
Derived from student \\
transcript data; roughly 50 \\
categories
\end{tabular} & $\begin{array}{l}\text { Direct question; roughly } \\
100 \text { categories }\end{array}$ & $\begin{array}{l}\text { Direct question; roughly } 50 \\
\text { categories }\end{array}$ & $\begin{array}{l}\text { Direct question about first } \\
\text { bachelor's degree; hundreds } \\
\text { of categories }\end{array}$ & $\begin{array}{l}\text { Direct question about first } \\
\text { bachelor's degree; hundreds } \\
\text { of categories }\end{array}$ & $\begin{array}{l}\text { Direct question; hundreds } \\
\text { of categories }\end{array}$ & $\begin{array}{l}\text { Only field of highest } \\
\text { degree; } 20 \text { categories }\end{array}$ & $\begin{array}{l}\text { Direct question; } 18 \\
\text { categories }\end{array}$ & No information \\
\hline
\end{tabular}


Online Appendix Table 2a: Characteristics of SIPP Major Categories, 1984 to 1993 Waves

\begin{tabular}{l|c}
\hline Major: & $\beta^{\text {major }}$ \\
\hline Engineering and Computers & 1.37 \\
Mathematics and Statistics & 1.08 \\
Economics & 0.54 \\
Physical or Earth Sciences & 0.39 \\
Police Science and Law Enforcement & 0.23 \\
Business/Management & 0.18 \\
Nursing/Pharmacy/Health & 0.02 \\
Other & 0.02 \\
Biology & -0.17 \\
English and Journalism & -0.33 \\
Psychology & -0.42 \\
Liberal Arts and Humanities & -0.54 \\
Social Sciences & -0.55 \\
Home Economics & -0.56 \\
Vocational and Technical Studies & -0.79 \\
Agriculture or Forestry & -0.81 \\
Medicine and Dentistry & -0.99 \\
Law & -1.04 \\
Education & -1.23 \\
Religion or Theology & -2.59 \\
\hline Notes: Measure is given in standard deviations. $\beta^{\text {major }}$ is the earnings return to \\
the major, based on authors' calculations, and is estimated in the pooled data.
\end{tabular}


Online Appendix Table 2b: Characteristics of SIPP Major Categories, 1996 to 2008 Waves

\begin{tabular}{l|c}
\hline Major: & $\beta^{\text {major }}$ \\
\hline Pre-Professional & 1.80 \\
Engineering & 1.11 \\
Computer and Information & 1.01 \\
Mathematics and Statistics & 0.61 \\
Health Sciences & 0.51 \\
Business/Management & 0.46 \\
Natural Sciences & 0.39 \\
Other & 0.08 \\
Liberal Arts and Humanities & -0.10 \\
Foreign Languages & -0.17 \\
Communications & -0.31 \\
Psychology & -0.42 \\
Social Sciences & -0.44 \\
Art and Architecture & -0.55 \\
English and Literature & -0.61 \\
Agriculture or Forestry & -0.96 \\
Philosophy/Religion/Theology & -0.96 \\
Education & -1.05 \\
\hline Notes: Measure is given in standard deviations. $\beta^{\text {major }}$ is the earnings \\
return to the major, based on authors' calculations, and is estimated in \\
the pooled data. &
\end{tabular}


Online Appendix Table 3: Employment as a Function of Entry Conditions and Major Characteristics

\begin{tabular}{|c|c|c|c|c|c|c|c|}
\hline & $(1)$ & $(2)$ & (3) & $(4)$ & (5) & (6) & $(7)$ \\
\hline Entry unemployment rate $\left(\mathrm{U}_{\mathrm{c}}\right)$ & $\begin{array}{l}-0.0011 \\
(0.0016)\end{array}$ & $\begin{array}{l}-0.0006 \\
(0.0021)\end{array}$ & $\begin{array}{l}-0.0005 \\
(0.0018)\end{array}$ & $\begin{array}{c}0.0014 \\
(0.0024)\end{array}$ & $\begin{array}{c}0.0003 \\
(0.0020)\end{array}$ & $\begin{array}{c}-0.0046^{* * *} \\
(0.0013)\end{array}$ & $\begin{array}{c}-0.0042 * * * \\
(0.0016)\end{array}$ \\
\hline Post*Uc & & & & $\begin{array}{l}-0.0045 \\
(0.0030)\end{array}$ & $\begin{array}{c}-0.0066^{* *} \\
(0.0033)\end{array}$ & & $\begin{array}{l}-0.0038 \\
(0.0028)\end{array}$ \\
\hline $\mathrm{U}_{\mathrm{c}}{ }^{*}$ potexp & $\begin{array}{c}0.0002 \\
(0.0007)\end{array}$ & $\begin{array}{l}-0.0001 \\
(0.0007)\end{array}$ & $\begin{array}{l}-0.0001 \\
(0.0006)\end{array}$ & $\begin{array}{l}-0.0003 \\
(0.0008)\end{array}$ & $\begin{array}{l}-0.0001 \\
(0.0007)\end{array}$ & $\begin{array}{c}0.0014 * * \\
(0.0006)\end{array}$ & $\begin{array}{c}0.0017 * * \\
(0.0007)\end{array}$ \\
\hline Post*Uc*potexp & & & & $\begin{array}{c}0.0000 \\
(0.0015)\end{array}$ & $\begin{array}{l}-0.0003 \\
(0.0018)\end{array}$ & & $\begin{array}{c}-0.0076 * * * \\
(0.0021)\end{array}$ \\
\hline $\mathrm{U}_{\mathrm{c}}{ }^{*}$ potexp ${ }^{2}$ & $\begin{array}{l}-0.0001 \\
(0.0001)\end{array}$ & $\begin{array}{c}0.0000 \\
(0.0001)\end{array}$ & $\begin{array}{c}0.0000 \\
(0.0001)\end{array}$ & $\begin{array}{l}-0.0000 \\
(0.0001)\end{array}$ & $\begin{array}{c}0.0000 \\
(0.0001)\end{array}$ & $\begin{array}{c}-0.0001^{* *} \\
(0.0001)\end{array}$ & $\begin{array}{c}-0.0001^{* *} \\
(0.0001)\end{array}$ \\
\hline Post* $\mathrm{U}_{\mathrm{c}} *$ potexp $^{2}$ & & & & $\begin{array}{c}0.0002 \\
(0.0003)\end{array}$ & $\begin{array}{c}0.0004 \\
(0.0004)\end{array}$ & & $\begin{array}{c}0.0020 * * * \\
(0.0006)\end{array}$ \\
\hline$\beta^{\text {major }}$ & & $\begin{array}{l}0.0040 * \\
(0.0023)\end{array}$ & & & & & \\
\hline Post $* \beta^{\text {major }}$ & & & & $\begin{array}{c}0.0071 \\
(0.0059)\end{array}$ & $\begin{array}{c}0.0072 \\
(0.0053)\end{array}$ & & \\
\hline$\beta^{\text {major }} *$ potexp & $\begin{array}{c}0.0013^{* * *} \\
(0.0004)\end{array}$ & $\begin{array}{c}0.0012^{* * *} \\
(0.0004)\end{array}$ & $\begin{array}{c}0.0012^{* * *} \\
(0.0003)\end{array}$ & $\begin{array}{c}0.0016^{* * *} \\
(0.0004)\end{array}$ & $\begin{array}{c}0.0014 * * * \\
(0.0004)\end{array}$ & & \\
\hline Post $^{*} \beta^{\text {major }_{*}}$ potexp & & & & $\begin{array}{c}-0.0023^{* *} \\
(0.0011) \\
\end{array}$ & $\begin{array}{l}-0.0022 * \\
(0.0012)\end{array}$ & & \\
\hline$\beta^{\text {major }_{*}} \mathrm{U}_{\mathrm{c}}$ & $\begin{array}{c}0.0015 \\
(0.0011)\end{array}$ & $\begin{array}{c}0.0018 \\
(0.0011)\end{array}$ & $\begin{array}{l}0.0017 * \\
(0.0010)\end{array}$ & $\begin{array}{c}0.0033^{* *} \\
(0.0015)\end{array}$ & $\begin{array}{c}0.0034 * * * \\
(0.0013)\end{array}$ & & \\
\hline Post $* \beta^{\text {major }} * U_{c}$ & & & & $\begin{array}{c}-0.0049 * * \\
(0.0023)\end{array}$ & $\begin{array}{c}-0.0053^{* *} \\
(0.0021)\end{array}$ & & \\
\hline$\beta^{\text {major }} * U_{c}^{*}$ potexp & $\begin{array}{l}-0.0003^{*} \\
(0.0002)\end{array}$ & $\begin{array}{l}-0.0003 * \\
(0.0002)\end{array}$ & $\begin{array}{l}-0.0003^{*} \\
(0.0002)\end{array}$ & $\begin{array}{c}-0.0005^{* * *} \\
(0.0002)\end{array}$ & $\begin{array}{c}-0.0005^{* * *} \\
(0.0002)\end{array}$ & & \\
\hline Post $* \beta^{\text {major }} * \mathrm{U}_{\mathrm{c}} *$ potexp & & & & $\begin{array}{c}0.0007 \\
(0.0007) \\
\end{array}$ & $\begin{array}{r}0.0008 \\
(0.0007) \\
\end{array}$ & & \\
\hline Major fixed effects & $\mathrm{X}$ & & $\mathrm{X}$ & $\mathrm{X}$ & $\mathrm{X}$ & & \\
\hline Grad year fixed effects & & $\mathrm{X}$ & $\mathrm{X}$ & & $\mathrm{X}$ & & \\
\hline Cluster at grad year-division & $\mathrm{X}$ & $\mathrm{X}$ & & $\mathrm{X}$ & & $\mathrm{X}$ & $\mathrm{X}$ \\
\hline Observations & 61,825 & 61,825 & 61,825 & 61,825 & 61,825 & 254,636 & 254,636 \\
\hline R-squared & 0.148 & 0.148 & 0.155 & 0.151 & 0.156 & 0.020 & 0.021 \\
\hline
\end{tabular}

*** $\mathrm{p}<0.01, * * \mathrm{p}<0.05, * \mathrm{p}<0.1$

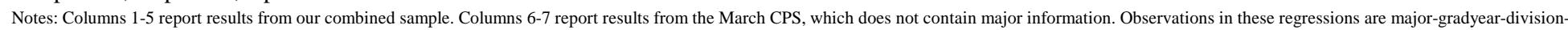

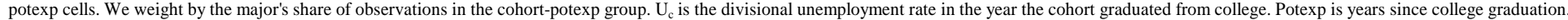

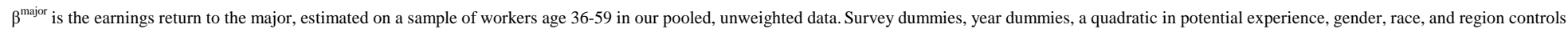

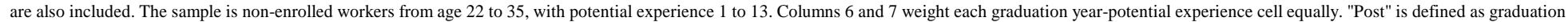
years 2004 and later. 
Online Appendix Table 4: Full-time Employment as a Function of Entry Conditions and Major Characteristics

\begin{tabular}{|c|c|c|c|c|c|c|c|}
\hline & $(1)$ & $(2)$ & $(3)$ & $(4)$ & $(5)$ & $(6)$ & $(7)$ \\
\hline Entry unemployment rate $\left(\mathrm{U}_{\mathrm{c}}\right)$ & $\begin{array}{c}-0.0166 * * * \\
(0.0030) \\
\end{array}$ & $\begin{array}{c}-0.0181^{* * *} \\
(0.0038) \\
\end{array}$ & $\begin{array}{c}-0.0180 * * * \\
(0.0033) \\
\end{array}$ & $\begin{array}{c}-0.0188 * * * \\
(0.0042) \\
\end{array}$ & $\begin{array}{c}-0.0204^{* * *} \\
(0.0038) \\
\end{array}$ & $\begin{array}{c}-0.0110^{* * *} \\
(0.0020) \\
\end{array}$ & $\begin{array}{c}-0.0106 * * * \\
(0.0023) \\
\end{array}$ \\
\hline Post*Uc & & & & $\begin{array}{c}0.0091^{*} \\
(0.0049)\end{array}$ & $\begin{array}{c}0.0047 \\
(0.0059)\end{array}$ & & $\begin{array}{l}-0.0024 \\
(0.0042)\end{array}$ \\
\hline $\mathrm{U}_{\mathrm{c}}{ }^{*}$ potexp & $\begin{array}{c}0.0058^{* * *} \\
(0.0012)\end{array}$ & $\begin{array}{c}0.0059 * * * \\
(0.0013)\end{array}$ & $\begin{array}{c}0.0059 * * * \\
(0.0010)\end{array}$ & $\begin{array}{c}0.0072 * * * \\
(0.0015)\end{array}$ & $\begin{array}{c}0.0073^{* * *} \\
(0.0012)\end{array}$ & $\begin{array}{c}0.0032 * * * \\
(0.0008)\end{array}$ & $\begin{array}{c}0.0035^{* * *} \\
(0.0009)\end{array}$ \\
\hline Post*Uc*potexp & & & & $\begin{array}{c}-0.0097 * * * \\
(0.0026)\end{array}$ & $\begin{array}{c}-0.0102^{* * *} \\
(0.0026)\end{array}$ & & $\begin{array}{c}-0.0076^{*} \\
(0.0040)\end{array}$ \\
\hline $\mathrm{U}_{\mathrm{c}}{ }^{*}$ potexp $^{2}$ & $\begin{array}{c}-0.0005^{* * *} \\
(0.0001)\end{array}$ & $\begin{array}{c}-0.0004^{* * *} \\
(0.0001)\end{array}$ & $\begin{array}{c}-0.0004^{* * *} \\
(0.0001)\end{array}$ & $\begin{array}{c}-0.0006^{* * *} \\
(0.0001)\end{array}$ & $\begin{array}{c}-0.0006^{* * *} \\
(0.0001)\end{array}$ & $\begin{array}{c}-0.0002^{* * *} \\
(0.0001)\end{array}$ & $\begin{array}{c}-0.0002^{* * *} \\
(0.0001)\end{array}$ \\
\hline Post $^{*} \mathrm{U}_{\mathrm{c}} *$ potexp $^{2}$ & & & & $\begin{array}{c}0.0019 * * * \\
(0.0007)\end{array}$ & $\begin{array}{c}0.0015^{* * *} \\
(0.0005)\end{array}$ & & $\begin{array}{c}0.0013 \\
(0.0010)\end{array}$ \\
\hline$\beta^{\text {major }}$ & & $\begin{array}{c}0.0506 * * * \\
(0.0045)\end{array}$ & & & & & \\
\hline Post $* \beta^{\text {major }}$ & & & & $\begin{array}{c}0.0084 \\
(0.0093)\end{array}$ & $\begin{array}{c}0.0094 \\
(0.0081)\end{array}$ & & \\
\hline$\beta^{\text {major }_{*}}$ potexp & $\begin{array}{c}-0.0023^{* * *} \\
(0.0006)\end{array}$ & $\begin{array}{c}-0.0020^{* * *} \\
(0.0006)\end{array}$ & $\begin{array}{c}-0.0023^{* * *} \\
(0.0005)\end{array}$ & $\begin{array}{c}-0.0021^{* * *} \\
(0.0006)\end{array}$ & $\begin{array}{c}-0.0020^{* * *} \\
(0.0006)\end{array}$ & & \\
\hline Post* $\beta^{\text {major }}{ }^{*}$ potexp & & & & $\begin{array}{c}-0.0044^{* * *} \\
(0.0017) \\
\end{array}$ & $\begin{array}{c}-0.0045^{* *} \\
(0.0017) \\
\end{array}$ & & \\
\hline$\beta^{\text {major }_{*}} U_{c}$ & $\begin{array}{c}0.0074 * * * \\
(0.0027)\end{array}$ & $\begin{array}{c}0.0070^{* * *} \\
(0.0026)\end{array}$ & $\begin{array}{c}0.0075^{* * *} \\
(0.0019)\end{array}$ & $\begin{array}{c}0.0142 * * * \\
(0.0035)\end{array}$ & $\begin{array}{c}0.0141^{* * *} \\
(0.0026)\end{array}$ & & \\
\hline Post $^{*} \beta^{\text {major }_{*}} \mathrm{U}_{\mathrm{c}}$ & & & & $\begin{array}{c}-0.0191^{* * *} \\
(0.0043)\end{array}$ & $\begin{array}{c}-0.0191^{* * *} \\
(0.0036)\end{array}$ & & \\
\hline$\beta^{\text {major }} * U_{c}^{*}$ potexp & $\begin{array}{c}-0.0008^{* *} \\
(0.0003)\end{array}$ & $\begin{array}{c}-0.0007^{* *} \\
(0.0003)\end{array}$ & $\begin{array}{c}-0.0008^{* * *} \\
(0.0003)\end{array}$ & $\begin{array}{c}-0.0017^{* * *} \\
(0.0004)\end{array}$ & $\begin{array}{c}-0.0017^{* * * *} \\
(0.0003)\end{array}$ & & \\
\hline Post $* \beta^{\text {major }} * U_{c} *$ potexp & & & & $\begin{array}{c}0.0024^{* *} \\
(0.0012) \\
\end{array}$ & $\begin{array}{c}0.0025^{* *} \\
(0.0011) \\
\end{array}$ & & \\
\hline Major fixed effects & $\mathrm{X}$ & & $\mathrm{X}$ & $\mathrm{X}$ & $\mathrm{X}$ & & \\
\hline Grad year fixed effects & & $\mathrm{X}$ & $\mathrm{X}$ & & $\mathrm{X}$ & & \\
\hline Cluster at grad year-division & $\mathrm{X}$ & $\mathrm{X}$ & & $\mathrm{X}$ & & $\mathrm{X}$ & $\mathrm{X}$ \\
\hline Observations & 61,752 & 61,752 & 61,752 & 61,752 & 61,752 & 254,636 & 254,636 \\
\hline R-squared & 0.183 & 0.173 & 0.186 & 0.187 & 0.189 & 0.041 & 0.041 \\
\hline
\end{tabular}

$* * * \mathrm{p}<0.01, * * \mathrm{p}<0.05, * \mathrm{p}<0.1$

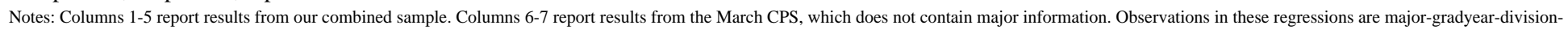

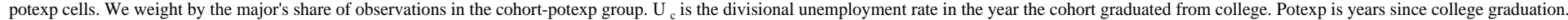

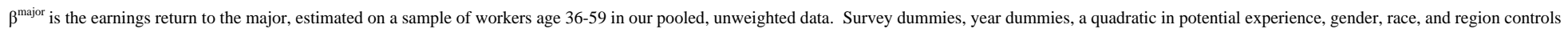

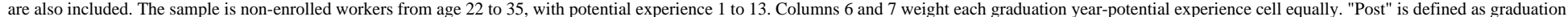
years 2004 and later. 
Online Appendix Table 5: Log Rate of Pay as a Function of Entry Conditions and Major Characteristics

\begin{tabular}{|c|c|c|c|c|c|c|c|}
\hline & $(1)$ & $(2)$ & (3) & (4) & (5) & (6) & $(7)$ \\
\hline Entry unemployment rate $\left(\mathrm{U}_{\mathrm{c}}\right)$ & $\begin{array}{c}-0.0106^{* *} \\
(0.0049)\end{array}$ & $\begin{array}{c}-0.0136 * * \\
(0.0063)\end{array}$ & $\begin{array}{c}-0.0128 * * * \\
(0.0037)\end{array}$ & $\begin{array}{l}-0.0086 \\
(0.0065)\end{array}$ & $\begin{array}{c}-0.0117 * * * \\
(0.0040)\end{array}$ & $\begin{array}{c}-0.0086^{* * *} \\
(0.0024)\end{array}$ & $\begin{array}{c}-0.0073^{* *} \\
(0.0028)\end{array}$ \\
\hline Post*Uc & & & & $\begin{array}{c}-0.0177 * * \\
(0.0077)\end{array}$ & $\begin{array}{l}-0.0095 \\
(0.0072)\end{array}$ & & $\begin{array}{l}-0.0068 \\
(0.0054)\end{array}$ \\
\hline $\mathrm{U}_{\mathrm{c}}{ }^{*}$ potexp & $\begin{array}{c}0.0043 * * \\
(0.0018)\end{array}$ & $\begin{array}{c}0.0048 * * \\
(0.0019)\end{array}$ & $\begin{array}{c}0.0047^{* * *} \\
(0.0012)\end{array}$ & $\begin{array}{c}0.0033 \\
(0.0021)\end{array}$ & $\begin{array}{c}0.0040^{* * *} \\
(0.0013)\end{array}$ & $\begin{array}{c}0.0014 \\
(0.0009)\end{array}$ & $\begin{array}{c}0.0010 \\
(0.0010)\end{array}$ \\
\hline Post*Uc*potexp & & & & $\begin{array}{c}0.0145^{* * *} \\
(0.0036)\end{array}$ & $\begin{array}{c}0.0098 * * \\
(0.0049)\end{array}$ & & $\begin{array}{l}-0.0036 \\
(0.0035)\end{array}$ \\
\hline $\mathrm{U}_{\mathrm{c}}{ }^{*}$ potexp ${ }^{2}$ & $\begin{array}{c}-0.0004^{* * *} \\
(0.0001)\end{array}$ & $\begin{array}{c}-0.0003 * * \\
(0.0001)\end{array}$ & $\begin{array}{c}-0.0003^{* * *} \\
(0.0001)\end{array}$ & $\begin{array}{l}-0.0003 * \\
(0.0002)\end{array}$ & $\begin{array}{c}-0.0003^{* * *} \\
(0.0001)\end{array}$ & $\begin{array}{c}-0.0001 \\
(0.0001)\end{array}$ & $\begin{array}{l}-0.0001 \\
(0.0001)\end{array}$ \\
\hline Post $^{*} \mathrm{U}_{\mathrm{c}} *$ potexp $^{2}$ & & & & $\begin{array}{c}-0.0023^{* * *} \\
(0.0007)\end{array}$ & $\begin{array}{c}-0.0019 * * \\
(0.0008)\end{array}$ & & $\begin{array}{c}0.0007 \\
(0.0011)\end{array}$ \\
\hline$\beta^{\text {major }}$ & & $\begin{array}{c}0.1536 * * * \\
(0.0054)\end{array}$ & & & & & \\
\hline Post* $\beta^{\text {major }}$ & & & & $\begin{array}{l}-0.0105 \\
(0.0108)\end{array}$ & $\begin{array}{l}-0.0101 \\
(0.0094)\end{array}$ & & \\
\hline$\beta^{\text {major }_{*}}$ potexp & $\begin{array}{c}0.0031^{* * *} \\
(0.0007)\end{array}$ & $\begin{array}{c}0.0034 * * * \\
(0.0007)\end{array}$ & $\begin{array}{c}0.0029 * * * \\
(0.0006)\end{array}$ & $\begin{array}{c}0.0028 * * * \\
(0.0008)\end{array}$ & $\begin{array}{c}0.0026^{* * *} \\
(0.0007)\end{array}$ & & \\
\hline Post* $\beta^{\text {major }} *$ potexp & & & & $\begin{array}{c}-0.0022 \\
(0.0022) \\
\end{array}$ & $\begin{array}{l}-0.0021 \\
(0.0022) \\
\end{array}$ & & \\
\hline$\beta^{\text {major }_{*}} U_{c}$ & $\begin{array}{c}0.0059 * * \\
(0.0029)\end{array}$ & $\begin{array}{c}0.0013 \\
(0.0031)\end{array}$ & $\begin{array}{c}0.0057^{* * *} \\
(0.0021)\end{array}$ & $\begin{array}{c}0.0062 \\
(0.0038)\end{array}$ & $\begin{array}{c}0.0058 * * \\
(0.0027)\end{array}$ & & \\
\hline Post $* \beta^{\text {major }} * \mathrm{U}_{\mathrm{c}}$ & & & & $\begin{array}{l}-0.0010 \\
(0.0048) \\
\end{array}$ & $\begin{array}{c}-0.0008 \\
(0.0040) \\
\end{array}$ & & \\
\hline$\beta^{\text {major }} * U_{c}{ }^{*}$ potexp & $\begin{array}{l}-0.0007 * \\
(0.0004)\end{array}$ & $\begin{array}{l}-0.0002 \\
(0.0004)\end{array}$ & $\begin{array}{c}-0.0007^{* *} \\
(0.0003)\end{array}$ & $\begin{array}{l}-0.0007 \\
(0.0004)\end{array}$ & $\begin{array}{c}-0.0007^{* *} \\
(0.0004)\end{array}$ & & \\
\hline Post* $\beta^{\text {major }^{*}} * \mathrm{U}_{\mathrm{c}}{ }^{*}$ potexp & & & & $\begin{array}{l}-0.0015 \\
(0.0015) \\
\end{array}$ & $\begin{array}{c}-0.0014 \\
(0.0014) \\
\end{array}$ & & \\
\hline Major fixed effects & $\mathrm{X}$ & & $\mathrm{X}$ & $\mathrm{X}$ & $\mathrm{X}$ & & \\
\hline Grad year fixed effects & & $\mathrm{X}$ & $\mathrm{X}$ & & $\mathrm{X}$ & & \\
\hline Cluster at grad year-division & $\mathrm{X}$ & $\mathrm{X}$ & & $\mathrm{X}$ & & $\mathrm{X}$ & $\mathrm{X}$ \\
\hline Observations & 56,585 & 56,585 & 56,585 & 56,585 & 56,585 & 208,431 & 208,431 \\
\hline R-squared & 0.994 & 0.994 & 0.994 & 0.994 & 0.994 & 0.144 & 0.144 \\
\hline
\end{tabular}

\section{${ }^{* * *} \mathrm{p}<0.01,{ }^{* *} \mathrm{p}<0.05,{ }^{*} \mathrm{p}<0.1$}

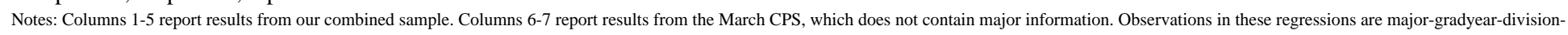

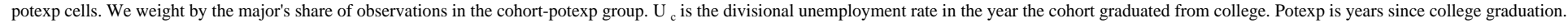

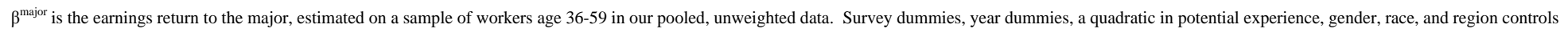

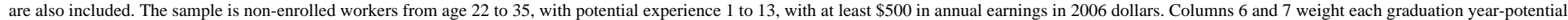
experience cell equally. "Post" is defined as graduation years 2004 and later. 
Online Appendix Table 6: Occupation Earnings as a Function of Entry Conditions and Major Characteristics

\begin{tabular}{|c|c|c|c|c|c|c|c|}
\hline & $(1)$ & $(2)$ & (3) & (4) & (5) & (6) & (7) \\
\hline Entry unemployment rate $\left(\mathrm{U}_{\mathrm{c}}\right)$ & $\begin{array}{c}-0.0066 * * * \\
(0.0022) \\
\end{array}$ & $\begin{array}{c}-0.0058 * * \\
(0.0029) \\
\end{array}$ & $\begin{array}{c}-0.0062 * * \\
(0.0025) \\
\end{array}$ & $\begin{array}{c}-0.0060^{* *} \\
(0.0030) \\
\end{array}$ & $\begin{array}{c}-0.0065^{* *} \\
(0.0027) \\
\end{array}$ & $\begin{array}{c}-0.0036 * \\
(0.0022) \\
\end{array}$ & $\begin{array}{c}-0.0021 \\
(0.0028) \\
\end{array}$ \\
\hline Post*Uc & & & & $\begin{array}{l}-0.0024 \\
(0.0035)\end{array}$ & $\begin{array}{l}-0.0001 \\
(0.0048)\end{array}$ & & $\begin{array}{c}-0.0021 \\
(0.0043)\end{array}$ \\
\hline $\mathrm{U}_{\mathrm{c}}{ }^{*}$ potexp & $\begin{array}{c}0.0025^{* * *} \\
(0.0008)\end{array}$ & $\begin{array}{c}0.0020 * * \\
(0.0009)\end{array}$ & $\begin{array}{c}0.0022 * * * \\
(0.0008)\end{array}$ & $\begin{array}{c}0.0024^{* * *} \\
(0.0009)\end{array}$ & $\begin{array}{c}0.0024^{* * *} \\
(0.0009)\end{array}$ & $\begin{array}{c}0.0012 \\
(0.0009)\end{array}$ & $\begin{array}{c}0.0009 \\
(0.0010)\end{array}$ \\
\hline Post*Uc*potexp & & & & $\begin{array}{c}0.0031 \\
(0.0023)\end{array}$ & $\begin{array}{l}0.0053 * \\
(0.0031)\end{array}$ & & $\begin{array}{c}-0.0048 \\
(0.0034)\end{array}$ \\
\hline $\mathrm{U}_{\mathrm{c}}{ }^{*}$ potexp ${ }^{2}$ & $\begin{array}{c}-0.0002^{* * *} \\
(0.0001)\end{array}$ & $\begin{array}{c}-0.0001 * * \\
(0.0001)\end{array}$ & $\begin{array}{c}-0.0002 * * \\
(0.0001)\end{array}$ & $\begin{array}{c}-0.0002^{* * *} \\
(0.0001)\end{array}$ & $\begin{array}{c}-0.0002^{* * *} \\
(0.0001)\end{array}$ & $\begin{array}{c}-0.0001 * \\
(0.0001)\end{array}$ & $\begin{array}{l}-0.0001 \\
(0.0001)\end{array}$ \\
\hline Post $^{*} \mathrm{U}_{\mathrm{c}} *$ potexp $^{2}$ & & & & $\begin{array}{l}-0.0004 \\
(0.0004)\end{array}$ & $\begin{array}{l}-0.0009 * \\
(0.0005)\end{array}$ & & $\begin{array}{c}0.0015 * * \\
(0.0006)\end{array}$ \\
\hline$\beta^{\text {major }}$ & & $\begin{array}{c}0.1304 * * * \\
(0.0033)\end{array}$ & & & & & \\
\hline Post* $\beta^{\text {major }}$ & & & & $\begin{array}{c}-0.0048 \\
(0.0071)\end{array}$ & $\begin{array}{l}-0.0043 \\
(0.0060)\end{array}$ & & \\
\hline$\beta^{\text {major }} *$ potexp & $\begin{array}{l}-0.0002 \\
(0.0004)\end{array}$ & $\begin{array}{c}0.0003 \\
(0.0004)\end{array}$ & $\begin{array}{c}-0.0002 \\
(0.0004)\end{array}$ & $\begin{array}{l}-0.0003 \\
(0.0005)\end{array}$ & $\begin{array}{l}-0.0003 \\
(0.0004)\end{array}$ & & \\
\hline Post* $\beta^{\text {major }} *$ potexp & & & & $\begin{array}{c}0.0014 \\
(0.0012)\end{array}$ & $\begin{array}{c}0.0013 \\
(0.0013)\end{array}$ & & \\
\hline$\beta^{\text {major }_{*}} \mathrm{U}_{\mathrm{c}}$ & $\begin{array}{c}0.0024 \\
(0.0017)\end{array}$ & $\begin{array}{c}0.0002 \\
(0.0017)\end{array}$ & $\begin{array}{c}0.0028 * * \\
(0.0014)\end{array}$ & $\begin{array}{l}0.0041^{*} \\
(0.0023)\end{array}$ & $\begin{array}{c}0.0046 * * \\
(0.0018)\end{array}$ & & \\
\hline Post* $\beta^{\text {major }} * \mathrm{U}_{\mathrm{c}}$ & & & & $\begin{array}{c}-0.0066^{* *} \\
(0.0029) \\
\end{array}$ & $\begin{array}{c}-0.0071^{* * *} \\
(0.0026) \\
\end{array}$ & & \\
\hline$\beta^{\text {major }} * U_{c} *$ potexp & $\begin{array}{l}-0.0002 \\
(0.0002)\end{array}$ & $\begin{array}{c}0.0000 \\
(0.0002)\end{array}$ & $\begin{array}{l}-0.0002 \\
(0.0002)\end{array}$ & $\begin{array}{l}-0.0004 \\
(0.0003)\end{array}$ & $\begin{array}{l}-0.0004 * \\
(0.0002)\end{array}$ & & \\
\hline Post $* \beta^{\text {major }} * U_{c} *$ potexp & & & & $\begin{array}{c}0.0012 \\
(0.0008) \\
\end{array}$ & $\begin{array}{c}0.0012 \\
(0.0008) \\
\end{array}$ & & \\
\hline Major fixed effects & $\mathrm{X}$ & & $\mathrm{X}$ & $\mathrm{X}$ & $\mathrm{X}$ & & \\
\hline Grad year fixed effects & & $\mathrm{X}$ & $\mathrm{X}$ & & $\mathrm{X}$ & & \\
\hline Cluster at grad year-division & $\mathrm{X}$ & $\mathrm{X}$ & & $\mathrm{X}$ & & $\mathrm{X}$ & $\mathrm{X}$ \\
\hline Observations & 55,670 & 55,670 & 55,670 & 55,670 & 55,670 & 196,501 & 196,501 \\
\hline R-squared & 0.307 & 0.292 & 0.310 & 0.307 & 0.310 & 0.050 & 0.050 \\
\hline
\end{tabular}

*** $\mathrm{p}<0.01, * * \mathrm{p}<0.05, * \mathrm{p}<0.1$

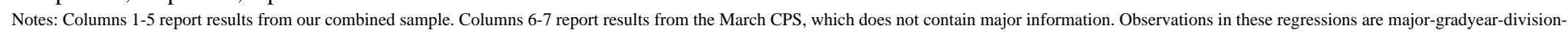

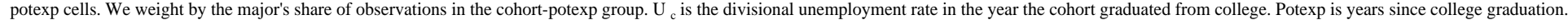

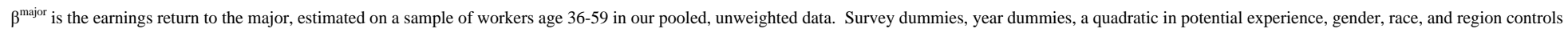

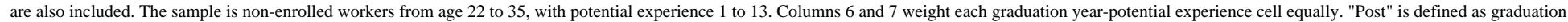
years 2004 and later. 
Online Appendix Table 7: Match Quality as a Function of Entry Conditions and Major Characteristics

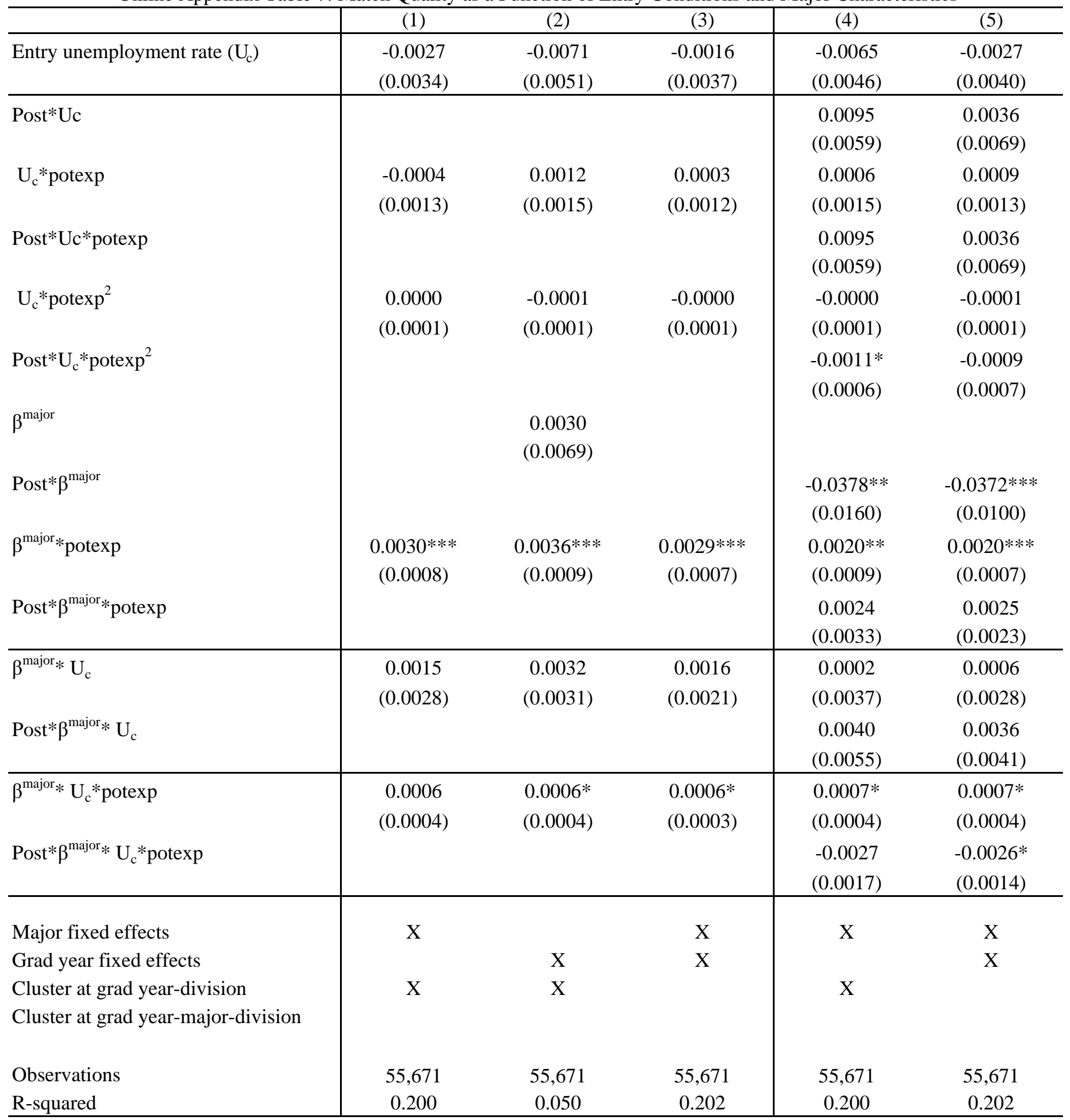

$* * * \mathrm{p}<0.01, * * \mathrm{p}<0.05, * \mathrm{p}<0.1$

Notes: The sample is our combined sample. Observations in these regressions are major-gradyear-division-potexp cells. We weight by the major's share of observations in the cohort-potexp group. $U_{c}$ is the divisional unemployment rate in the year the cohort graduated from college. Potexp is years since college graduation. $\beta^{\text {major }}$ is the earnings return to the major, estimated on a sample of workers age 36-59 in our pooled, unweighted data. Survey dummies, year dummies, a quadratic in potential experience, gender, race, and region controls are also included. The sample is non-enrolled workers from age 22 to 35, with potential experience 1 to 13 , with at least $\$ 500$ in annual earnings in 2006 dollars. "Post" is defined as graduation years 2004 and later. 
Online Appendix Table 8a: Dept of Education to Early SIPP Major Crosswalk

\begin{tabular}{|c|c|c|c|}
\hline Early SIPP Major & Dept of Education Major & Ed Share (Men) & Ed Share (Women) \\
\hline Agriculture/Forestry & Agriculture/Ag Science & 1.00 & 1.00 \\
\hline Biology & Biological Sciences & 1.00 & 1.00 \\
\hline Business/Mgmt & Finance & 0.16 & 0.10 \\
\hline Business/Mgmt & Marketing & 0.21 & 0.25 \\
\hline Business/Mgmt & Business Mgmt/Admin & 0.14 & 0.20 \\
\hline Business/Mgmt & Accounting & 0.49 & 0.45 \\
\hline Economics & Economics & 1.00 & 1.00 \\
\hline Education & Secondary Education & 0.08 & 0.03 \\
\hline Education & Other Education and Library Science & 0.92 & 0.97 \\
\hline Engineering/Computers & All Other Engineering & 0.21 & 0.23 \\
\hline Engineering/Computers & Chemical Engineering & 0.04 & 0.08 \\
\hline Engineering/Computers & Civil Engineering & 0.07 & 0.08 \\
\hline Engineering/Computers & Computer Programming & 0.05 & 0.09 \\
\hline Engineering/Computers & Computer/Info Tech & 0.24 & 0.28 \\
\hline Engineering/Computers & Electrical Engineering & 0.14 & 0.10 \\
\hline Engineering/Computers & Engineering Tech & 0.06 & 0.05 \\
\hline Engineering/Computers & Mechanical Engineering & 0.14 & 0.08 \\
\hline Engineering/Computers & Precision Production/Industrial Arts & 0.04 & 0.02 \\
\hline English/Journalism & Communications & 0.49 & 0.44 \\
\hline English/Journalism & Journalism & 0.40 & 0.45 \\
\hline English/Journalism & Letters: Lit, Writing, Other & 0.10 & 0.10 \\
\hline Home Economics & Family and Consumer Science & 1.00 & 1.00 \\
\hline Law & Public Administration and Law & 1.00 & 1.00 \\
\hline Liberal Arts/Humanities & Foreign Language & 1.00 & 1.00 \\
\hline Math/Statistics & Mathematics & 1.00 & 1.00 \\
\hline Medicine/Dentistry & -- & -- & -- \\
\hline Nursing/Pharm/Health & Misc. Business and Med. Support & 0.54 & 0.24 \\
\hline Nursing/Pharm/Health & Fitness and Nutrition & 0.19 & 0.10 \\
\hline Nursing/Pharm/Health & Other Med/Health Services & 0.17 & 0.26 \\
\hline Nursing/Pharm/Health & Medical Tech & 0.02 & 0.02 \\
\hline Nursing/Pharm/Health & Public Health & 0.02 & 0.02 \\
\hline Nursing/Pharm/Health & Nursing & 0.07 & 0.35 \\
\hline Other & Leisure Studies and Basic Skills & 0.11 & 0.10 \\
\hline Other & Architecture & 0.19 & 0.09 \\
\hline Other & Commercial Art and Design & 0.15 & 0.21 \\
\hline Other & Art History and Fine Arts & 0.21 & 0.27 \\
\hline Other & Film and Other Arts & 0.13 & 0.14 \\
\hline Other & Music and Speech/Drama & 0.22 & 0.19 \\
\hline Physical/Earth Science & Multidisciplinary or General Science & 0.16 & 0.29 \\
\hline Physical/Earth Science & Physics & 0.23 & 0.09 \\
\hline Physical/Earth Science & Chemistry & 0.34 & 0.40 \\
\hline Physical/Earth Science & Earth and Other Physical Sci & 0.27 & 0.22 \\
\hline Police Science & Protective Services & 1.00 & 1.00 \\
\hline Psychology & Psychology & 0.85 & 0.77 \\
\hline Psychology & Social Work and Human Resources & 0.15 & 0.23 \\
\hline Religion/Theology & Philosophy and Religion & 1.00 & 1.00 \\
\hline Social Sciences & Other Social Science & 0.28 & 0.42 \\
\hline Social Sciences & Area, Ethnic, and Civic Studies & 0.03 & 0.06 \\
\hline Social Sciences & Political Science & 0.29 & 0.23 \\
\hline Social Sciences & History & 0.26 & 0.16 \\
\hline Social Sciences & International Relations & 0.05 & 0.07 \\
\hline Social Sciences & Environmental Studies & 0.09 & 0.06 \\
\hline Vocational Studies & -- & -- & -- \\
\hline
\end{tabular}


Online Appendix Table 8b: Dept of Education to Late SIPP Major Crosswalk

\begin{tabular}{|c|c|c|c|}
\hline Early SIPP Major & Dept of Education Major & Ed Share (Men) & Ed Share (Women) \\
\hline Agriculture/Forestry & Agriculture and Agr. Science & 1 & 1 \\
\hline Art/Architecture & Precision Production/ Industrial Arts & 0.16 & 0.02 \\
\hline Art/Architecture & Architecture & 0.17 & 0.09 \\
\hline Art/Architecture & Commercial Art and Design & 0.14 & 0.23 \\
\hline Art/Architecture & Art History and Fine Arts & 0.19 & 0.3 \\
\hline Art/Architecture & Film and Other Arts & 0.12 & 0.15 \\
\hline Art/Architecture & Music and Speech/Drama & 0.21 & 0.21 \\
\hline Business/Mgmt & Economics & 0.13 & 0.08 \\
\hline Business/Mgmt & Finance & 0.14 & 0.09 \\
\hline Business/Mgmt & Marketing & 0.12 & 0.19 \\
\hline Business/Mgmt & Business Mgmt/Administration & 0.43 & 0.42 \\
\hline Business/Mgmt & Accounting & 0.18 & 0.23 \\
\hline Communications & Communications & 0.83 & 0.81 \\
\hline Communications & Journalism & 0.17 & 0.19 \\
\hline Computer/Info Tech & Computer and Info Tech & 0.83 & 0.75 \\
\hline Computer/Info Tech & Computer Programming & 0.17 & 0.25 \\
\hline Education & Secondary Education & 0.08 & 0.03 \\
\hline Education & Other Education and Library Science & 0.88 & 0.87 \\
\hline Education & Family and Consumer Science & 0.04 & 0.1 \\
\hline Engineering & All Other Engineering & 0.32 & 0.38 \\
\hline Engineering & Mechanical Engineering & 0.21 & 0.12 \\
\hline Engineering & Electrical Engineering & 0.21 & 0.16 \\
\hline Engineering & Civil Engineering & 0.11 & 0.13 \\
\hline Engineering & Chemical Engineering & 0.06 & 0.12 \\
\hline Engineering & Engineernig Tech & 0.09 & 0.08 \\
\hline English/Literature & Letters: Lit., Writing, Other & 1 & 1 \\
\hline Foreign Language & Foreign Language & 1 & 1 \\
\hline Health Sciences & Misc. Business/Med Support & 0.54 & 0.24 \\
\hline Health Sciences & Fitness and Nutrition & 0.19 & 0.1 \\
\hline Health Sciences & Other Med/Health Services & 0.17 & 0.26 \\
\hline Health Sciences & Medical Tech & 0.02 & 0.02 \\
\hline Health Sciences & Public Health & 0.02 & 0.02 \\
\hline Health Sciences & Nursing & 0.07 & 0.35 \\
\hline Liberal Arts/Humanities & -- & -- & -- \\
\hline Math/Statistics & Mathematics & 1.00 & 1.00 \\
\hline Nature Sciences & Multidisciplinary/General Science & 0.07 & 0.08 \\
\hline Nature Sciences & Physics & 0.09 & 0.02 \\
\hline Nature Sciences & Chemistry & 0.14 & 0.11 \\
\hline Nature Sciences & Earth and Other Physical Science & 0.11 & 0.06 \\
\hline Nature Sciences & Biological Sciences & 0.6 & 0.73 \\
\hline Other & Leisure Studies and Basic Skills & 1 & 1 \\
\hline Philogophy/Religion & Philosophy and Religion & 1 & 1 \\
\hline Pre-Professional & Public Admin and Law & 1 & 1 \\
\hline Psychology & Psychology & 0.85 & 0.77 \\
\hline Psychology & Social Work and Human Resources & 0.15 & 0.23 \\
\hline Social Sciences & Other Social Sciences & 0.23 & 0.36 \\
\hline Social Sciences & Area, Ethnic, and Civic Studies & 0.02 & 0.05 \\
\hline Social Sciences & Political Science & 0.24 & 0.19 \\
\hline Social Sciences & Protective Serivces & 0.19 & 0.14 \\
\hline Social Sciences & History & 0.21 & 0.14 \\
\hline Social Sciences & International Relations & 0.04 & 0.06 \\
\hline Social Sciences & Environmental Studies & 0.08 & 0.05 \\
\hline
\end{tabular}

